\title{
POTENCIALIDADES DE DIFERENTES LINHAGENS DE LEVEDURA DA ESPÉCIE Saccharomyces cerevisiae NA TECNOLOGIA DE AGUARDENTE DE CANA
}

\section{CARLOS ALBERTO FRANÇA RIBEIRO \\ Engenheiro Agrônomo}

Orientador: Prof. Dr. Jorge Horii

Dissertação apresentada à Escola Superior de Agricultura "Luiz de Queiroz", da Universidade de São Paulo, para a obtenção do título de Mestre em Ciências, Área de Concentração: Ciência e Tecnologia de Alimentos.

PIRACICABA

Estado de São Paulo - Brasil

Janeiro - 1997 
Dados Internacionais de Catalogação na Publicação (CIP) DIVISÃO DE BIBLIOTECA E DOCUMENTAÇÃO - Campus “Luiz de Queiroz"/USP

Ribeiro, Carlos Alberto França

Potencialidades de diferentes linhagens de levedura da espécie Saccharomyces cerevisiae na tecnologia de aguardente de cana / Carlos Alberto França Ribeiro. - Piracicaba, 1997.

106 p. : il.

Dissertação (mestrado) - Escola Superior de Agricultura Luiz de Queiroz, 1997.

Bibliografia.

1. Aguardente de cana-de-açúcar 2. Bebida alcoolica 3. Fermentação 4. Levedura I. Título. 


\section{POTENCIALIDADES DE DIFERENTES LINHAGENS DE LEVEDURA DA ESPÉCIE Saccharomyces cerevisiae NA TECNOLOGIA DE AGUARDENTE DE CANA}

\section{CARLOS ALBERTO FRANÇÁ RIBEIRO}

Aprovação: 24.03.1997

Comissão julgadora:

Prof. Dr. Jorge Horii

ESALQ/USP

Prof. Dr. Luiz Eduardo Gutierrez

ESALQ/USP

Prof. Dr. Waldemar G. Venturini Fo․

FCA/UNESP

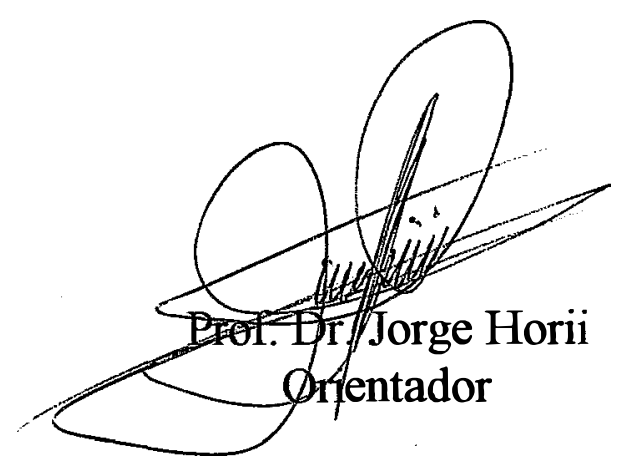


Aos meus pais, Calisto e Aracelis e irmãos, Jorge e Ana, dedico. 


\section{AGRADECIMENTOS}

A todos que contribuiram para a realização deste trabalho, em especial:

- Ao Prof. Dr. Jorge Horii, por me ceder a oportunidade, pela dedicação e atenção dispensadas;

- À Regina Helena Gonçalves, Rubens Cesar Pereira e Sylvino Luiz Torrezan;

- À André Vinicius Sesso, Constante Christofoletti, Eduardo Giovani Arthuso, Pedro Dorival Lucentini, Pedro Rossini Filho e Wilson Januário;

- Ao Prof. Dr. Fernando Valadares Novaes;

- Ao Prof. Dr. João Nunes Nogueira e à José Carlos Teixeira Mendes;

- À Ana Flora da Cruz Ganeo, Gislaine Maria Martins Nóbilo, Regina Lucia de M. Loureiro e Rosemary L.S. Mandro;

- A Carlota Boralli Prudente dos Anjos, Cecília Helena Nogueira, Denise Almeida Leme Baptista e Rosalina Fátima Ocagne;

- Ao Departamento de Ciência e Tecnologia Agroindustrial da Escola Superior de Agricultura "Luiz de Queiroz" da Universidade de São Paulo, pela oportunidade cedida;

- À CAPES, pelo auxílio cedido na forma de bolsa de estudos. 


\section{SUMÁRIO}

Página

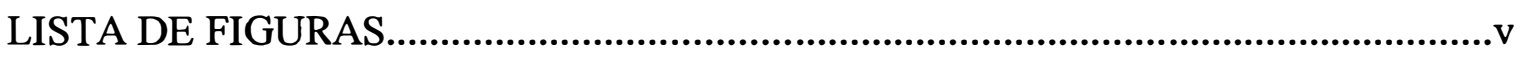

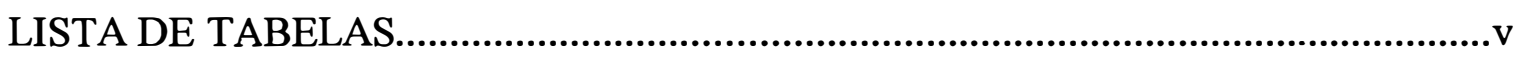

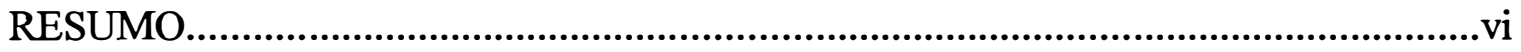

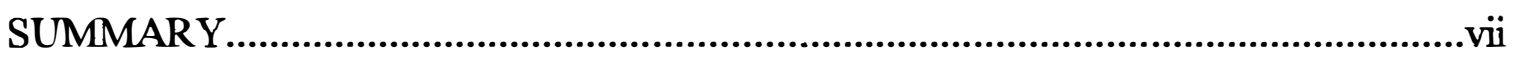

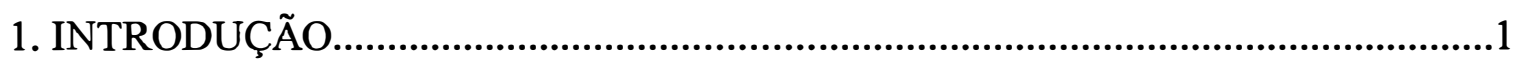

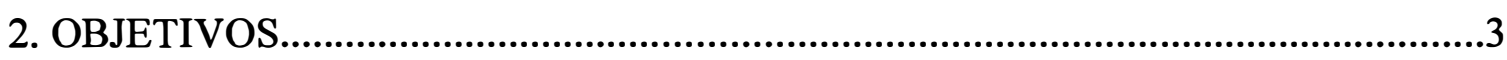

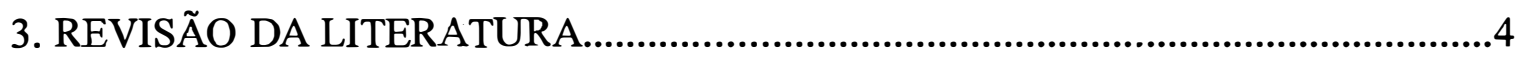

3.1. Matéria-prima..................................................................................................

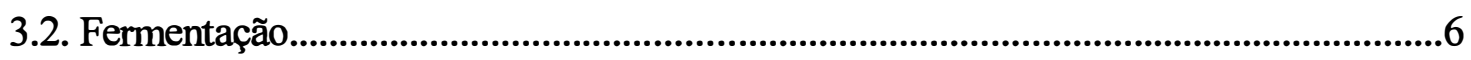

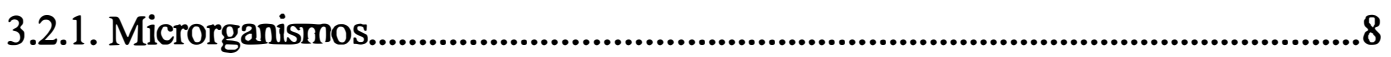

3.2.1.1. Leveduras floculantes.......................................................................10

3.2.1.2. Leveduras não produtoras de sulfeto de hidrogênio............................12

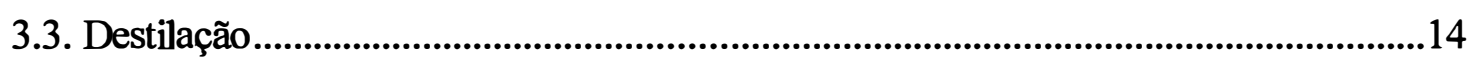

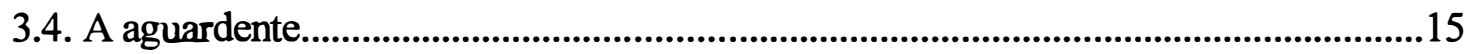

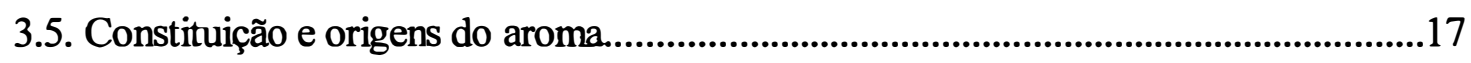

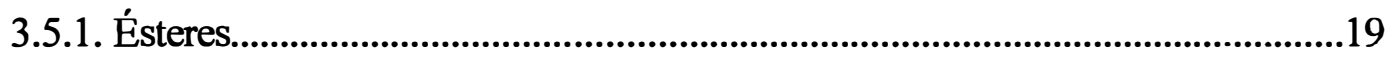

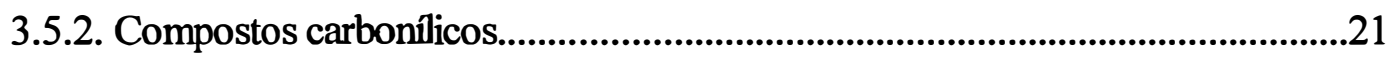

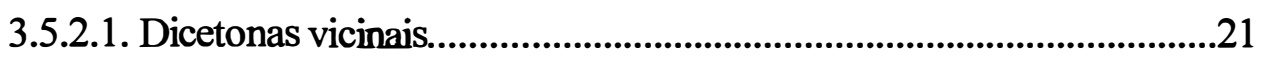

3.5.2.2. Aldeídos............................................................................................22

3.5.2.3. Acetais............................................................................................ 23

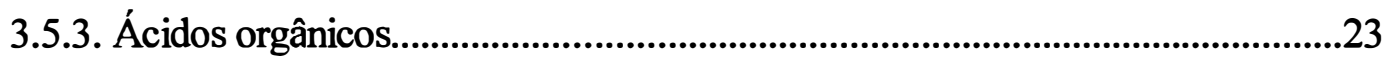

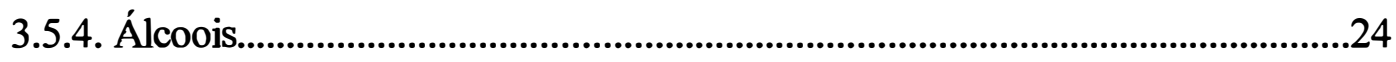

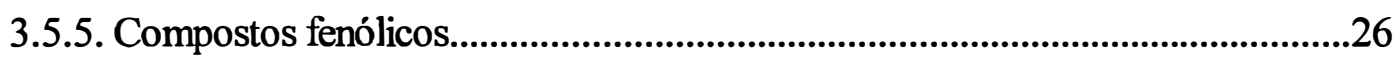

3.5.6. Compostos sulfurados................................................................................26

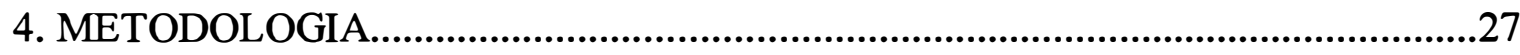

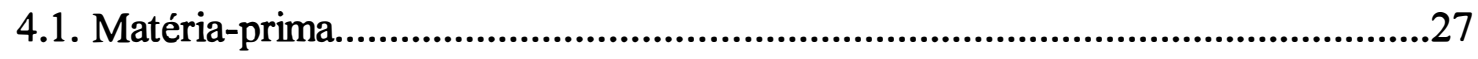




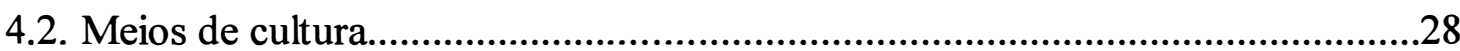

4.2.1. Meios de manutenção e de propagação inicial dos microrganismos............28

4.2.2. Meio para a seleção da linhagem não produtora de sulfeto de hidrogênio.29

4.2.3. Meio para a propagação final dos microrganismos e realização do

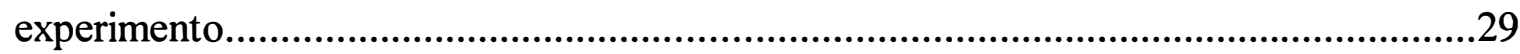

4.2.3.1. Extração do caldo.......................................................................30

4.2.3.2. Preparo do mosto..........................................................................30

4.3. Microrganismos..............................................................................................

4.3.1. Seleção da linhagem não produtora de sulfeto de hidrogênio $\left(\mathrm{H}_{2} \mathrm{~S}\right)$...........32

4.3.2. Propagação dos microrganismos...................................................................33

4.4. Fermentação......................................................................................................34

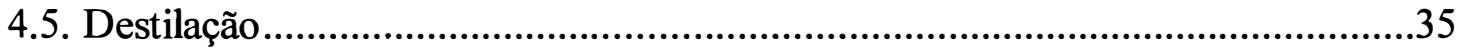

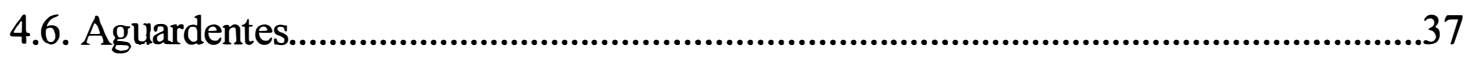

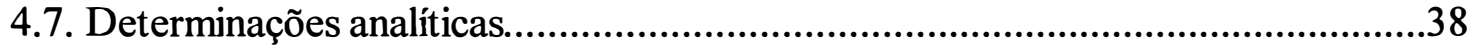

4.7.1. Determinações fisico-químicas..........................................................................38

4.7.1.1. Determinações cromatográficas.........................................................39

4.8. Cálculos dos parâmetros de fermentação..................................................................40

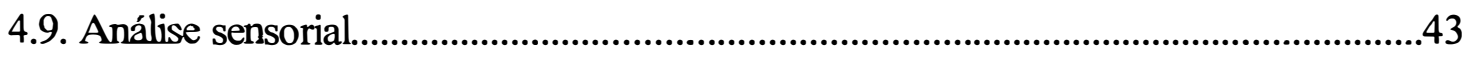

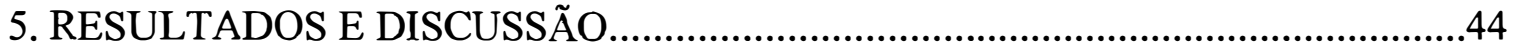

5.1. Seleção da linhagem não produtora de $\mathrm{H}_{2} \mathrm{~S}$.........................................................4

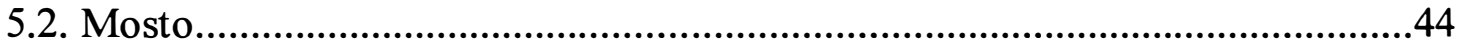

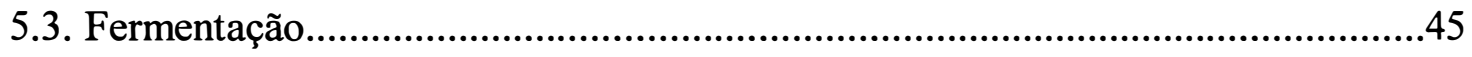

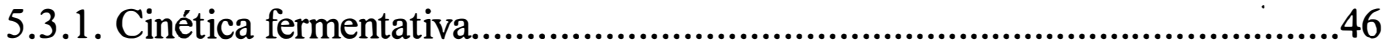

5.3.2. Análises cromatográficas do vinho ........................................................52

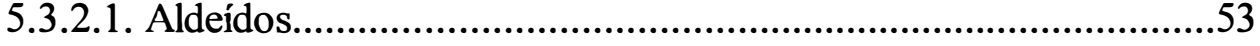

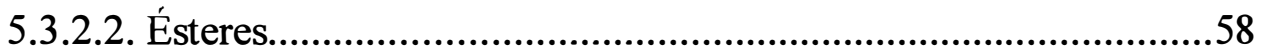

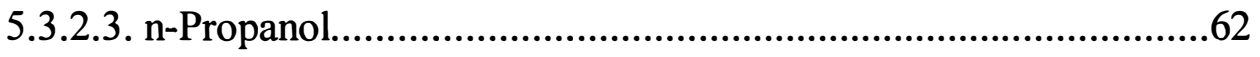

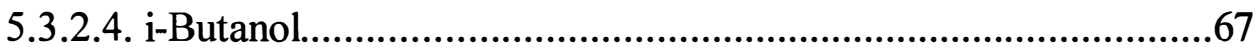


5.3.2.5. Álcool i-Amîico.....................................................................

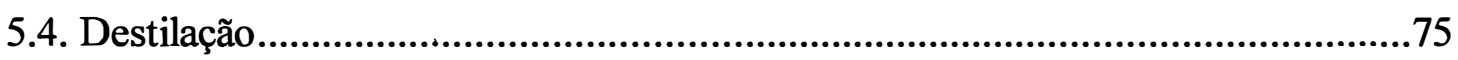

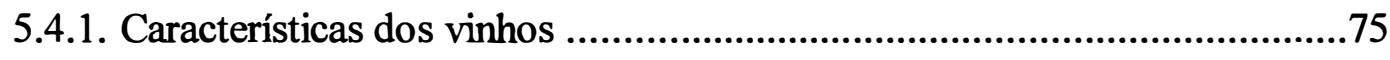

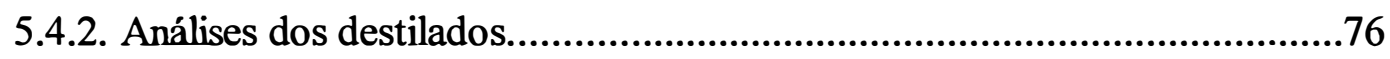

5.5. Padronização e análises das aguardentes............................................................79

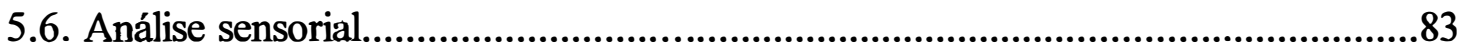

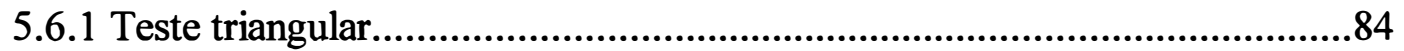

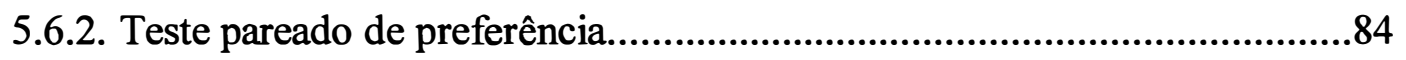

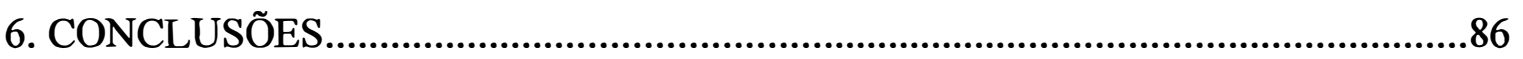

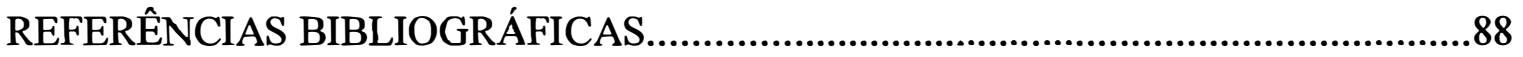

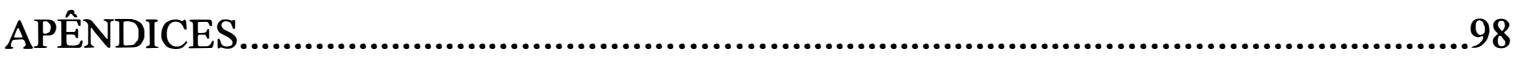




\section{LISTA DE FIGURAS}

Figura 1. Esquema do aparelho de destilação tipo "Besnard-Estève"............................ 36

Figura 2. Resultados da cinética fermentativa - Ensaio LF - Médias................................ 49

Figura 3. Resultados da cinética fermentativa - Ensaio IZ 987 - Médias......................... 50

Figura 4. Resultados da cinética fermentativa - Ensaio FP - Médias............................... 51

Figura 5. Produção de aldeídos durante a fermentação - Ensaio LF - Médias................ 54

Figura 6. Produção de aldeídos durante a fermentação - Ensaio IZ - Médias..................55

Figura 7. Produção de aldeídos durante a fermentação - Ensaio FP - Médias................ 56

Figura 8. Produção de ésteres durante a fermentação - Ensaio LF - Médias.................. 59

Figura 9. Produção de ésteres durante a fermentação - Ensaio IZ - Médias.................... 60

Figura 10. Produção de ésteres durante a fermentação - Ensaio FP - Médias.................. 61

Figura 11. Produção de n-Propanol durante a fermentação - Ensaio LF - Médias............63

Figura 12. Produção de n-Propanol durante a fermentação - Ensaio IZ - Médias............ 64

Figura 13. Produção de n-Propanol durante a fermentação - Ensaio FP - Médias............ 65

Figura 14. Produção de i-Butanol durante a fermentação - Ensaio LF - Médias.............. 68

Figura 15. Produção de i-Butanol durante a fermentação - Ensaio IZ - Médias............... 69

Figura 16. Produção de i-Butanol durante a fermentação - Ensaio FP - Médias.............. 70

Figura 17. Produção de álcool i-Amilico durante a fermentação - Ensaio LF - Médias.. 72

Figura 18. Produção de álcool i-Amílico durante a fermentação - Ensaio IZ - Médias... 73

Figura 19. Produção de álcool i-Amilico durante a fermentação - Ensaio FP - Médias.. 74

Figura 20. Acidez das frações destiladas - Ensaio LF - Médias......................................... 77

Figura 21. Acidez das frações destiladas - Ensaio IZ - Médias......................................... 78

Figura 22. Acidez das frações destiladas - Ensaio FP - Médias..........................................78 


\section{LISTA DE TABELAS}

Tabela 1. Características dos mostos utilizados nos ensaios....................................45

Tabela 2. Resultados de parâmetros de fermentação das três linhagens estudadas........47

Tabela 3. Resultados das determinações cromatográficas durante as fermentações nos diferentes tratamentos.................................................................53

Tabela 4. Resultados das análises dos vinhos destinados à destilação.........................75

Tabela 5. Análises das aguardentes obtidas dos tratamentos.....................................80

Tabela 6. Análises da mistura de frações dos destilados correspondentes à cauda.........82

Tabela 7. Resultados do testes triangulares efetuados nas aguardentes.......................84

Tabela 8. Resultados do teste pareado de preferência entre os tratamentos FP e LF....84

Tabela 9. Resultados do teste pareado de preferência entre os tratamentos LF e IZ.. ...85

Tabela 10. Resultados do teste pareado de preferência entre os tratamentos FP e IZ.....85 


\section{POTENCIALIDADES DE DIFERENTES LINHAGENS DE LEVEDURA DA ESPÉCIE Saccharomyces cerevisiae NA TECNOLOGIA DE AGUARDENTE DE CANA}

\section{RESUMO}

Três linhagens de levedura da espécie Saccharomyces cerevisiae, sendo duas floculantes, das quais uma não produtora de sulfeto de hidrogênio, foram avaliadas para se verificar suas potencialidades em tecnologia de aguardente de cana-de-açúcar. $\mathrm{O}$ acompanhamento da cinética da fermentação mostrou melhores resultados de eficiência de fermentação, fator de conversão de substrato em etanol e velocidade específica de crescimento pela linhagem IZ 987, que foram de $89,9 \%, 0,46 \mathrm{~g} . \mathrm{g}^{-1}$ e $0,0996 \mathrm{~h}^{-1}$, respectivamente, linhagem também responsável pela maior produção de álcoois superiores, $376 \mathrm{mg} .100 \mathrm{~mL}^{-1}$ de etanol a $100 \%$, inerente à sua característica de não produzir $\mathrm{H}_{2} \mathrm{~S}$. A melhor produtividade de fermentação, de $3,40 \mathrm{~g} \cdot \mathrm{L}^{-1} \cdot \mathrm{h}^{-1}$, foi a obtida pela linhagem floculante. A linhagem isolada à partir do fermento prensado proporcionou os menores valores dos parâmetros cinéticos estudados.

Foi verificada a influência das linhagens nas características sensoriais das aguardentes, e a aguardente produzida pela levedura floculante obteve preferência pelo painel de degustadores.

As determinações físico-químicas estudadas sobre as aguardentes mostraram a dificuldade de se relacionar a composição à qualidade sensorial das aguardentes, sugerindo a ampliação do estudo em trabalhos futuros. 


\section{POTENCIALITIES OF DIFFERENT Saccharomyces cerevisiae STRAINS FOR THE SUGAR CANE SPIRIT TECHNOLOGY}

\section{SUMMARY}

Three yeast strains of Saccharomyces cerevisiae specie, two flocculants, one of them non hydrogen sulfide producer, were evaluated for their sugar cane spirit technology potential. The fermentation kinetics showed better results on fermentation

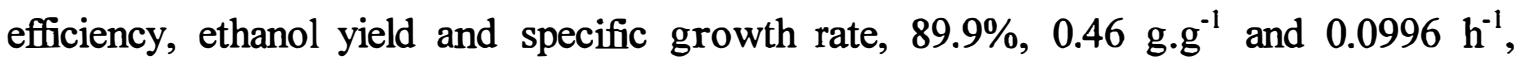
respectively, for the IZ 987 strain, that also produced larger amounts of higher alcohols, $376 \mathrm{mg} .100 \mathrm{~mL}^{-1}$ of $100 \%$ ethanol, inherent to their $\mathrm{H}_{2} \mathrm{~S}$ negative character. Better results of the ethanol productivity, about $3.40 \mathrm{~g} \cdot \mathrm{L}^{-1} \cdot \mathrm{h}^{-1}$, were performed by the flocculant strain. The strain isolated from baker's yeast promoted the poorest results.

Sensorial evaluation showed that the sensorial characteristics of the spirits were influenced by the strains and the spirit made by the flocculant yeast was preferred by the tasters panel.

Physic-chemical analysis of spirits showed the difficulty of establishing relationships between their composition and the sensorial quality, spreading the subjects for further works. 


\section{INTRODUÇÃO}

De fabricação simples ou até mesmo rudimentar, a aguardente de cana vem a cada dia ganhando mercado nas diversas classes sociais.

O processo de fermentação, no panorama nacional, dispõe basicamente de duas possibilidades, quanto ao microrganismo empregado, que são: a fermentação natural ou o "pé caipira" e o fermento prensado comercial. Os produtores de melhor nível tecnológico, raros em nosso pais, adotam a tecnologia alcooleira, caracterizada por parâmetros como rendimento e produtividade de fermentação dentre outros critérios quantitativos do processo. A pesquisa nacional, escassa na área de bebidas, ainda não sedimentou tais parâmetros, relacionando-os à qualidade global do produto final.

Contrastando com esta situação estão as indústrias estrangeiras da cerveja, do vinho e das bebidas destiladas como a do "whisky" e a do "brandy", nas quais as pesquisas para a adoção de um tipo de microrganismo portador de características tecnológicas desejáveis, estendem-se à manipulação genética.

Frente à diversidade existente e à necessidade de melhor aproveitamento de certas particularidades microbianas de interesse, gerada pela exploração do seu 
metabolismo em processos biotecnológicos, estudamos as potencialidades de três linhagens de levedura, sendo duas floculantes, das quais uma não produtora de sulfeto de hidrogênio, na produção de aguardente de cana, tendo em vista a definição e otimização de um processo e sua influência na qualidade da bebida. 


\section{OBJETIVOS}

O presente trabalho teve como objetivos investigar as potencialidades de três linhagens de levedura da espécie Saccharomyces cerevisiae e de suas peculiaridades para a produção de aguardente de cana-de-açúcar, através do acompanhamento cinético da fermentação e da formação de compostos secundários durante a mesma, bem como de determinações analíticas e sensoriais dos destilados compostos por critério definido sobre o fracionamento da destilação. 


\section{REVISÃO BIBLIOGRÁFICA}

A aguardente de cana é uma bebida tipicamente brasileira, primeiramente consumida pelos escravos, que evoluiu posteriormente como produto tradicional do meio rural e de cidades do interior. Por uma série de razões e talvez até por algum tipo de preconceito, a aguardente até pouco tempo não era consumida pelas classes sociais mais abastadas. A divulgação da bebida, até mesmo pelo êxodo rural, levou para a cidade o gosto interiorano da bebida dos escravos. Assim, de bebida consumida pelos habitantes de renda mais baixa, a aguardente de cana passou a ser procurada pelas classes de renda mais elevadas e nos grandes centros, o que vem contribuindo para uma demanda cada vez maior do produto, em quantidade e qualidade (Anônimo, 1988; Pinto, 1986).

\subsection{Matéria-prima}

A utilização da cana-de-açúcar como matéria-prima para a produção de aguardente data dos primórdios da nossa colonização, quando aqui foi introduzida esta cultura (Novaes, 1974). 
Associada à demanda industrial após a Segunda Guerra Mundial, observouse a necessidade de incrementos técnicos e científicos referentes à cana-de-açúcar. Os resultados do progresso tecnológico conseguido até os dias de hoje se traduzem principalmente pela melhoria da qualidade da matéria-prima, através do desenvolvimento de variedades melhoradas, da melhoria das técnicas de plantio, de tratos culturais, bem como do período e dos métodos de colheita, transporte e armazenamento (Lima, 1983).

Dentre os fatores da qualidade global da matéria-prima destinada à indústria de bebidas destiladas, a sua composição tem relação intrínseca com a qualidade sensorial do produto final (Harrison e Grahan, 1970).

Segundo Copersucar (1987), a composição química da cana-de-açúcar se faz variável, mediante muitos fatores, como condições climáticas, propriedades físicas, químicas e microbiológicas do solo, tipo de cultivo, variedade, idade, estádio de maturação e estado sanitário, entre outros fatores. Da sua composição, 99\% são devidos aos elementos hidrogênio, oxigênio e carbono. A distribuição dos componentes no colmo, em média, é de $74,5 \%$ em água, $25 \%$ em matéria orgânica e $0,5 \%$ de matéria mineral. O caldo, definido como uma solução impura e diluída de sacarose, glicose e frutose, é constituído de água e sólidos solúveis, sendo estes agrupados em açúcares e não açúcares, e este último em compostos orgânicos e inorgânicos. Os açúcares são representados pela sacarose, glicose e frutose. A sacarose tem um valor médio de $14 \%$, enquanto que os demais, dependendo do estádio de maturação, 0,2 e $0,4 \%$, respectivamente para frutose e glicose. Estes carboidratos que constituem o açúcar total, quando expressos em glicose, apresentam teores de 15 a 16\%. 
Os compostos orgânicos não açúcares são constituídos de substâncias nitrogenadas (proteínas, aminoácidos, etc.), gorduras, ceras, pectinas, ácidos (málico, succínico, aconítico, etc.) e de matérias corantes (clorofila, sacaretina e antocianina).

As substâncias inorgânicas, representadas pelas cinzas, têm como componentes principais: sílica, potássio, fósforo, cálcio, sódio, magnésio, enxofre, ferro e alumínio. Para o processamento, alguns componentes das cinzas são considerados importantes, tanto para a nutrição da levedura como para o processamento em si (Copersucar,1987).

\subsection{Fermentação}

O termo fermentação deriva do latim "fervere", ferver, descrevendo a aparência da ação de leveduras sobre extratos de frutas ou de grãos maltados. $\mathrm{O}$ aspecto de ebulição é devido à produção de bolhas de dióxido de carbono causada pelo catabolismo anaeróbio dos açúcares presentes no extrato. Entretanto, ao termo vêm sido aplicadas diferentes definições, tais como a bioquímica, que o define como um processo exotérmico no qual compostos orgânicos atuam como doadores ou receptores de elétrons, e a definida pelos microbiologistas industriais, mais ampla, que traduz fermentação como sendo qualquer processo de obtenção de produtos pela cultura de massa microbiana (Stambury e Whitaker, 1986). 
A fermentação alcoólica data do estabelecimento da civilização humana na Mesopotâmia, entre os rios Tigre e Eufrates, através do conhecimento destes antigos povos sobre a elaboração do vinho e da cerveja, porém a evolução do conhecimento sobre a fermentação alcoólica apenas foi possivel após Pasteur convencer o mundo científico do papel obrigatório das leveduras neste processo, em meados do século XIX. (Stambury e Whitaker, 1986; De Clerk,1957; Rose e Harrison, 1970).

Nas indústrias nacionais de aguardente o sistema de fermentação mais empregado é o de batelada alimentada com reaproveitamento de células pela simples decantação do vinho. Novaes (1992) relata os inconvenientes da recuperação por decantação como sendo: acentuada perda de fermento através do vinho, impossibilidade de se trabalhar com mostos ricos em açúcares, maior tempo de duração do processo, menores rendimento e produtividade em álcool, acidez mais elevada no destilado final, vinho com baixo teor alcoólico, maior consumo de nutrientes, maior consumo de ácido sulfúrico, tratamento ácido do fermento de forma não homogênea, redução da capacidade nominal do aparelho de destilação e maior volume de vinhaça. Em face a este sistema extremamente danoso, o autor sugere o processo de recuperação de fermento através da decantação, seguida da centrifugação da fração relativa ao pé-de-cuba remanescente e sua posterior diluição, seguida de seu tratamento ácido.

Rosini (1986) utilizou processo de fermentação com recuperação de fermento por centrifugação e recirculação na produção de vinho branco, conseguindo resultados promissores quanto aos parâmetros cinéticos por ele estudados, especialmente 
sobre a produtividade de etanol que se mostrou aproximadamente igual a cinco vezes a obtida pelo processo convencional e sobre o tempo de fermentação.

\subsubsection{Microrganismos}

Os microrganismos mais amplamente empregados na fermentação alcoólica, sobretudo na produção de bebidas fermento-destiladas, são os ascomicetos do gênero Saccharomyces. Sobre estas leveduras, o isolamento, a seleção e a utilização de culturas puras foram introduzidas com sucesso por Hansen no fim do século XIX, para a produção de cerveja. Esta técnica foi logo em seguida utilizada na fabricação de vinho por Müller-Thurgau e, recomendada por Paiarault em 1903 para a fermentação do rum (Rose e Harrison, 1971).

As leveduras empregadas na fabricação de aguardente no Brasil variam em função do processo de fermentação, que Valsechi (1960) classifica como: processo "caipira", que aproveita as leveduras provindas do campo, contaminando a matéria-prima, às quais se fornece condições adequadas para multiplicarem; processo misto, no qual o tratamento destinado à multiplicação das leveduras selvagens do processo caipira, é reforçado pela adição de fermento prensado; processo usando fermento prensado, empregando-se o fermento comercial industrializado, destinado à panificação; processo clássico usando fermento selecionado, onde se emprega culturas puras de linhagens previamente selecionadas. $\mathrm{O}$ autor afirma que, no processo caipira, a qualidade do fermento obtido é pura obra do acaso, onde podem ser obtidos desde fermentos extremamente bons até o extremo contrário, ou seja, fermentos extremamente ruins. A vantagem deste método, segundo o autor, é que através 
dele pode-se conseguir fermentos com adaptabilidade a meios adversos, situação comum nas pequenas destilarias de aguardente.

Segundo Franco (1978), no Brasil prevalece o uso do fermento prensado e da linhagem IZ 1904.

Nóbrega (1994), comparou a fermentação natural (processo “caipira") com a fermentação induzida (através do emprego de fermento prensado), observando maior produtividade e menor tempo de fermentação no ensaio de fermentação induzida.

Valsechi (1960) afirma ser o processo misto superior ao "caipira", por existir a possibilidade do aproveitamento tanto das leveduras provenientes do campo, quanto as do fermento prensado. Já o processo utilizando fermento prensado pode ser empregado em qualquer tipo de fábrica que não possua condições técnicas para o uso de fermento selecionado, permitindo o trabalho pleno da fábrica desde o primeiro dia da safra. Em relação ao processo clássico utilizando fermento selecionado, o autor relata ser seu emprego somente possível em indústrias de nível tecnológico elevado, para garantir condições de assepsia e as exigidas pela linhagem utilizada. Sobre as vantagens deste método destacam-se: obtenção de fermentações sadias, sendo mínimos os perigos de infecção; reduzido tempo de fermentação; pode-se rabalhar com mostos de alta concentração de açúcares; necessita-se de uma menor capacidade de domas; rendimento alcoólico elevado; produto final uniforme e de ótima qualidade.

Com o progresso da tecnologia de bebidas, as linhagens de levedura foram sendo selecionadas segundo características desejáveis ao processo. A produtividade e a eficiência de fermentação, a tolerância ao etanol e à temperatura, a resistência às altas 
concentrações de açúcares, a habilidade de flocular e de produzir ou não certos componentes do aroma das bebidas e a propriedade de produzir metabólitos anti-contaminantes (caráter "killer") são constantes fontes de interesse (Hammond, 1995).

\subsubsection{Leveduras floculantes}

A experimentação científica com leveduras floculantes vem ganhando impulso nas últimas décadas. Segundo De Clerck (1957), estas leveduras sedimentam no fundo das dornas não metabolisando todo o açúcar fermentescível do mosto cervejeiro, fato superado pelas vantagens tecnológicas, tais como a facilidade de separação.

Libicki e colaboradores (1988) e Logan e Hunt (1988), atribuem os baixos rendimentos obtidos com o uso de leveduras floculantes às limitações difusionais do substrato sobre os flocos, afimando ser esta a maior desvantagem destes microrganismos.

Souza e Teixeira (1991) testaram diferentes polimeros adsorventes em fermentações de meio sintético, empregando leveduras floculantes, visando aumentar a difusibilidade dos nutrientes através dos flocos, conseguindo efeitos positivos com polímero aniônico. Os resultados obtidos com este polímero foram: produtividade de $0,89 \mathrm{~g}$ de etanol . $\mathrm{L}^{-1} \cdot \mathrm{h}^{-1} \mathrm{e}$ velocidade específica de crescimento máxima de $0,263 \mathrm{~h}^{-1}$;

Prince e Barford (1988a), utilizando fermentador contínuo vertical, verificaram eficiente conversão pela linhagem floculante, a qual permitiu elevadas taxas de alimentação e alta concentração celular no fermentador, sem a necessidade de complexidades mecânicas, com níveis de produtividade muito superiores aos sistemas convencionais. 
Semelhantes resultados foram obtidos na fermentação do caldo de cana (Prince e Barford, 1988b).

Comberbach e Bu'Lock (1984) estudaram o desempenho de leveduras fortemente floculantes em fermentação de meio sintético com $10 \%$ de glicose, relatando as seguintes vantagens: trata-se do mais simples sistema de imobilização celular (autoimobilização), necessária aos processos contínuos de fermentação; não ocorre a diminuição da capacidade do fermentador (formação de espaço morto), provocada pelos suportes para imobilização empregados nos sistemas convencionais; permite a manutenção de elevada densidade celular, sem o custo gerado pela dúbia utilização de centrifugas, de outros separadores mecânicos ou pela ultrafiltração; os microrganismos contaminantes são facilmente retirados pelo próprio fluxo do sistema, não comprometendo seu desempenho.

Suzzi e colaboradores (1996) procuraram otimizar o processo de fermentação com reciclo de células para a fabricação do vinho, através o uso de leveduras fortemente floculantes imobilizadas em alginato de calcio, concluindo que estas leveduras são as mais indicadas para processos que envolvem a imobilização celular.

Parazai (1995), numa série de experimentos comparativos entre leveduras floculantes e a linhagem não floculante IZ 1904, constatou hegemonia da linhagem floculante Bonfim Floc na fermentação alcoólica do caldo de cana, podendo ser aproveitadas suas potencialidades tecnológicas em aplicações industnais para a produção de álcool e aguardente, com a exploração de sua característica altamente floculante, especialmente nos sistemas de fermentação onde se emprega a decantação para a separação das células. 
Prince e Barford (1988c) induziram floculência em linhagem pulverulenta de características desejáveis, através do controle do fornecimento de nutrientes, conferindo-lhe os beneficios tecnológicos advindos da floculação. Neste trabalho, os autores verificaram a dificuldade de se obter amostragem representativa mediante a floculação.

Stratford e Keenan (1988) elaboraram ensaios para contribuir com a busca de metodologia para a quantificação da floculação. Verificaram que fatores como tipo de frasco utilizado e a relação volume do frasco/volume de amostra e o tipo e velocidade de agitação, influem marcadamente nas deterninações, devendo portanto serem padronizados.

\subsubsection{Leveduras não produtoras de sulfeto de hidrogênio}

O sulfeto de hidrogênio, ácido sulfidrico ou gás sulfídrico $\left(\mathrm{H}_{2} \mathrm{~S}\right)$, possui odor repugnante, o que, aliado ao seu baixo limiar de detecção, "threshold", toma a sua presença nas bebidas indesejável.

Rankine (1963) investigou as causas da formação deste gás nos vinhos, relacionando-as com o metabolismo das leveduras. Em seu trabalho, observou que o "threshold" para o $\mathrm{H}_{2} \mathrm{~S}$ variava entre 0,1 e $1 \mathrm{ppb}$ em função do tipo de vinho, e que a formação de $\mathrm{H}_{2} \mathrm{~S}$ se dava a partir de enxofre elementar e de bissulfito, mas não de sulfato, cisteína, cistina ou metionina nas concentrações presentes no vinho. A formação a partir de sulfato foi verificada em meio sintético com $\mathrm{pH}$ inferior a $3 . \mathrm{O}$ autor ainda relata que a intensidade de produção do gás sulfidrico é dependente da linhagem de levedura. 
Zambonelli (1964a) fez determinações qualitativas e quantitativas de $\mathrm{H}_{2} \mathrm{~S}$ sobre 100 linhagens de levedura, verificando a existência de linhagens não produtoras e que as diferentes linhagens apresentavam diferentes habilidades de produção, sendo estas estáveis para cada linhagem. $\mathrm{O}$ autor observou a frequência de $2 \%$ de ocorrência de linhagens $\mathrm{H}_{2} \mathrm{~S}$ negativas em linhagens de interesse enológico e, verificou que a produção também se dava a partir dos íons sulfato e sulfito.

Posteriormente o mesmo autor (Zambonelli 1964b) investigou a formação de $\mathrm{H}_{2} \mathrm{~S}$ sob o ponto de vista genético, concluindo que a capacidade das leveduras de produzir ou não gás sulfidrico é estável, transmissível aos descendentes seguindo a hereditariedade mendeliana, sendo geneticamente controlada.

Giudici e colaboradores (1993), estudando a formação de álcoois superiores em vinho, observaram que as linhagens não produtoras de $\mathrm{H}_{2} \mathrm{~S}$ produziam maiores quantidades de álcoois superiores, principalmente de n-Propanol.

Giudici e Kunkee (1994) estudaram o efeito da deficiência de nitrogênio e de aminoácidos sulfurados na produção de gás sulfidrico pelas leveduras, em fermentações de suco de uva e de meio sintético. Verificaram que a produção do gás é influenciada pelos teores de amônia e de aminoácidos do meio, com exceção feita às leveduras $\mathrm{H}_{2} \mathrm{~S}$ negativas, que não prodưiram o gás sob qualquer condição; seus resultados foram semelhantes tanto em meio sintético quanto em suco de uva.

$\mathrm{Na}$ fermentação da cerveja, o sulfeto de hidrogênio produzido pelas leveduras é removido durante a maturação. $\mathrm{O}$ emprego de linhagens com menor capacidade de produção de $\mathrm{H}_{2} \mathrm{~S}$ pode reduzir o tempo exigido pelo processo (Hammond, 1995). 


\subsection{Destilação}

O princípio e a prática da destilação são muito antigos. Afirmações como a de Sinesio, escritor do século IV a.C., assegurando que os Egípcios conheciam os aparelhos e os métodos de destilação do vinho desde 40 séculos a.C. (Meloni, 1979), nos dão idéia sobre a idade deste processo de separação e purificação de misturas.

A prática da destilação para a obtenção de aguardente é realizada em aparelhos descontínuos (destilação simples) ou em aparelhos contínuos (destilação sistemática). Dentre os primeiros, os mais empregados são o alambique simples e o de três corpos; dentre os últimos, as torres ou colunas de destilação. Os alambiques, apesar dos limitados recursos, podem fornecer aguardente de qualidade aceitável dependendo das condições de operação (Stupiello, 1992).

Estes simples aparelhos foram responsáveis por grande parte da produção de bebidas destiladas no Canadá e nos Estados Unidos, durante a proibição da fabricação destas em virtude da aplicação da Lei Seca, após a qual foram sendo gradativamente substituídos por colunas (Amerine, Berg e Cruess, 1972).

No Brasil, a utilização dos alambiques restringe-se às pequenas instalaçōes para a produção de aguardente e de álcool vínico, e nas indústrias onde exige-se produções superiores a 2 mil litros por hora, são empregadas as colunas de destilação (Lima, 1975).

Segundo Stupiello (1992), sob o ponto de vista da qualidade da aguardente, tem sido admitido ao longo do tempo que as colunas de destilação produzem aguardentes 
inferiores às obtidas em aparelhos simples, mas, em realidade trata-se do condicionamento dos consumidores ou mesmo de consequência do projeto inadequado ou das condições operacionais dos aparelhos (ausência de conhecimentos técnicos do destilador). $\mathrm{O}$ autor afirma ainda que os alambiques simples não permitem um bom esgotamento do vinho e, em condições normais de operação, podem fornecer aguardentes ricas em componentes não álcoois, devido ao excesso de retrogradação determinado pelo desenho e dimensões do capitel, ou então, pela redestilação da fração de água fraca, fato que pode ser contomado com a separação das frações de cabeça, coração e cauda, visando aguardente de melhor qualidade. Neste tipo de aparelho o ciclo de destilação é longo, havendo maior consumo de água de resfriamento e de combustível. Já o produto obtido das colunas de destilação pode ser considerado como de melhor qualidade do que os obtidos nos aparelhos descontínuos, dependendo do tipo de projeto; tais aparelhos permitem melhor esgotamento do vinho, em função do controle adequado das vazões de vinho e de vapor, compensam o baixo grau alcoólico dos vinhos pelo controle da retrogradação dos condensadores e podem provocar condições seletivas de condensação produzindo, consequentemente, aguardentes de melhor qualidade.

\subsection{A aguardente}

Em 1991 foram produzidos no Brasil 1010 milhões de litros de aguardente, segundo a Folha de São Paulo (PRODUÇÃO DE AGUARDENTE EM 91, 1993), cabendo 90\% deste montante ao Estado de São Paulo. 
A aguardente de cana-de-açúcar é definida por Decreto Federal como bebida alcoólica obtida do destilado simples de cana-de-açúcar ou pela destilação de seu mosto fermentado, contendo graduação alcoólica de 38 a $54{ }^{\circ} \mathrm{GL}$ a $20^{\circ} \mathrm{C}$, devendo se enquadrar nos Padrões de Identidade e Qualidade, definidos por portaria deste Decreto (Brasil, 1974):

- Acidez volátil expressa em g de ácido acético x $100 \mathrm{~mL}^{-1}$ de álcool anidro: máximo de 0,150;

- Ésteres, expressos em g de acetato de etila x $100 \mathrm{~mL}^{-1}$ de álcool anidro: máximo de 0,200;

- Aldeídos, expressos em g de aldeído acético x $100 \mathrm{~mL}^{-1}$ de álcool anidro: máximo de 0,030;

- Álcoois superiores, expressos em g x $100 \mathrm{~mL}^{-1}$ de álcool anidro: máximo de 0,300;

- Álcool metílico em mL x $100 \mathrm{~mL}^{-1}$ de álcool anidro: máximo de 0,25;

- Componentes secundários, em g x $100 \mathrm{~mL}^{-1}$ de álcool anidro: mínimo de 0,200 e máximo de 0,650;

- Cobre: máximo de 5 ppm.

A constituição da aguardente confere as características sensoriais à bebida, na qual o odor desempenha notável papel na avaliação das características sensoriais pois nos dá noção de sua composição e de sua agradabilidade com muito mais fidelidade que o sabor. Esta maior sensibilidade ao odor que ao sabor pode ser esclarecida pelos diferentes mecanismos de olfato e de paladar. O mecanismo do olfato envolve um número superior de células (10 a 20 milhões) ao envolvido pelo paladar (90 a 150 mil) além destas estarem 
situadas em botões sensitivos formados pela união de 10 a 15 células, enquanto que as olfativas possuem estrutura ciliar e estão distribuídas ao longo da cavidade olfativa, o que lhes confere superfície de absorção muito maior (Hough, 1982).

As substâncias possuem diferentes valores limites de sensibilidade ("threshold"), como por exemplo o etanol, que possui valor limiar para odor em torno de 4

$\mathrm{mg} . \mathrm{L}^{-1}$ de ar, enquanto que para gosto se situa em torno de $130 \mathrm{mg} \cdot \mathrm{L}^{-1}$ de água (Rose e Harrison, 1970).

\subsection{Constituição e origens do aroma}

Para que a sensação de odor seja percebida, as substâncias necessitam estar acessíveis aos receptores olfativos, o que implica, em outras palavras, num certo grau de volatilidade destas substâncias ( Margalith e Schwartz, 1970).

Em bebidas destiladas a contribuição destas substâncias é marcante, devida à concentração dos voláteis pelo processo de destilação e, portanto, o modo de condução desta operação se mostra relevante na formação das características sensoriais do produto final (Suomalainen e Nykänen, 1966).

Com o avanço das metodologias analíticas verificou-se que a composição do "aroma" é extremamente complexa, sendo identificados mais de 400 compostos na fração "aroma". Isoladamente em "whisky", são encontrados no mínimo 200 componentes do "aroma", dentre os quais os ésteres formam o mais numeroso grupo, seguido por compostos 
carbonilicos (aldeídos, cetonas e acetais), ácidos orgânicos, álcoois e compostos fenólicos (Suomalainen e Nykänen, 1972).

Segundo Suomalainen (1970), as mesmas substâncias aparecem na fração "aroma", em caráter qualitativo, de diferentes bebidas, como cerveja, vinho, "cognac", "whisky" e rum. Em vista disso, parece evidente que as matérias-primas utilizadas pouco contribuem para a formação do "aroma", sendo seus componentes produzidos principalmente pelo metabolismo das leveduras durante a fermentação, dependendo do tipo de levedura utilizada e das condições sob a qual se conduz a fermentação e a destilação, em bebidas destiladas.

Suomalainen e Nykänen (1966) produziram destilados a partir de fermentação de meio glicosado sem nitrogênio; os mostos fermentados foram destilados na ausência e na presença de leveduras e ambos os produtos das destilações possuiam concentrações de álcoois e de ésteres muito semelhantes aos teores encontrados em "whisky" comercial, mostrando o papel das leveduras na formação destes compostos.

Salo e Suomalainen (1972), confeccionaram um "whisky" sintético com os componentes comumente encontrados em determinações cromatográficas da bebida, em mistura com destilado de grãos altamente retificado. Esta mistura foi então submetida a teste sensorial de diferença e foi facilmente diferenciada do "whisky"comercial. Tal resultado sugere que os componentes identificados não são totalmente responsáveis pelas características sensoriais da bebida, indicando a necessidade de se identificar novos compostos, ampliando assim as pesquisas na área de tecnologia de bebidas. 
Segundo Rose (1977), os componentes do "aroma" do rum até então identificados, não diferem substancialmente das demais bebidas destiladas. As diferenças existentes referem-se às proporções relativas de componentes particulares, que não são suficientes para diferenciá-lo de outras bebidas. O autor cita Mesley e colaboradores': “ele deve ser produzido pela fermentação e destilação de produtos de cana de açúcar, em região de plantio, possuindo as características sensoriais normalmente associadas ao rum”.

Faria (1989) conseguiu a separação de um pico nos cromatogramas de aguardentes, o qual foi relacionado pelo autor com um defeito sensorial, porém, não foi possivel a identificação de tal componente.

\subsection{1. Ésteres}

Principalmente produzidos por atividade metabólica de microrganismos e secundariamente por esterificação química, os ésteres formam um interessante grupo de componentes do "aroma" das bebidas alcoólicas, pois possuem odores agradáveis, os quais podem ser detectados em muito baixas concentrações, comprometendo o aroma das bebidas, somente quando presentes em elevadas concentrações (Hough, 1982; Suomalainen e Nykänen, 1972; Margalith e Schwartz, 1970).

O processo de biossíntese de ésteres ocorre paralelamente ao metabolismo de ácidos graxos, onde a primeira reação é a de formação de acil.CoA pela ativação por ácido

\footnotetext{
${ }^{1}$ MESLEY, R.J.; LISLE, D.B.; RICHARDS, C.P. et al. Annales de Technologie Agricole, Paris, (no prelo). apud ROSE, A.H. Economic microbiology volume1: alcoholic beverages. London: Academic Press, 1977. 760p.
} 
graxo ou cetoácido, seguida pela separação do grupo acil, que pode ocorrer por alcoólise, formando um éster ou por hidrólise, formando um ácido livre (Suomalainen e Nykänen, 1972).

A concentração de ésteres nas bebidas depende da linhagem de levedura, de seu crescimento e das condições de fermentação (Rose e Harrison, 1970).

Groboillot et al. (1989), monitorando a formação de compostos voláteis na fermentação de mosto de beterraba com concentrações iniciais de glicose e inóculo de $110 \mathrm{~g}$. $\mathrm{L}^{-1}$ e $5,5 \mathrm{~g} \cdot \mathrm{L}^{-1}$, respectivamente, observaram o acúmulo máximo de ésteres no final da fermentação, com a concentração de $17 \mathrm{mg} \cdot \mathrm{L}^{-1}$.

Em vinhos, a concentração de ésteres totais expressos em acetato de etila varia entre 200 e $400 \mathrm{mg} . \mathrm{L}^{-1}$. Em "brandies" esta situa-se entre 80 e $800 \mathrm{mg} . \mathrm{L}^{-1}$ (Amerine et al, 1972).

Ramsay e Berry (1984), verificando o efeito da temperatura na formação de ésteres em mosto de "whisky", encontraram o valor máximo de $57 \mathrm{mg}$ de acetato de etila. $\mathrm{L}^{-1}$, no tratamento de fermentação a $30^{\circ} \mathrm{C}$.

Zee (1984), avaliando diferentes variedades de uva na composição dos voláteis do "brandy", obteve de traços a 105,6 mg de acetato de etila. $\mathrm{L}^{-1}$, observando que nas primeiras frações do destilado (fração cabeça) se encontravam os maiores teores de acetato de etila, que se situavam entre 224 e $511 \mathrm{mg} \cdot \mathrm{L}^{-1}$.

Batiz e Rosado (1977) encontraram de 42 a $558 \mathrm{mg}$ de acetato de etila . $\mathrm{L}^{-1}$ nos runs comerciais de Porto Rico. 
Gutierrez (1990) observou teores de ésteres totais em aguardentes de cana que se situaram entre 2192 e $3688 \mathrm{mg}$ de acetato de etila. $\mathrm{L}^{-1}$ de etanol.

Salo (1970), desenvolvendo metodologia para a determinação do limite de detecção de alguns componentes do "aroma" de bebidas alcoólicas, obteve o valor de 17 ppm para o acetato de etila, em solução de destilado de grãos a 9,4\% $\left(\mathrm{m}^{-1} \mathrm{~m}^{-1}\right)$ de etanol, atribuindo sua importância à concentração em que este se encontra nas bebidas.

Em menor intensidade e velocidade ocorre a esterificação não enzímica, a qual desempenha importante papel no desenvolvimento do aroma das bebidas destiladas; Devido a maior concentração de álcool etilico tanto nos meios de fermentação quanto na bebida destilada, os ésteres formados em maior quantidade são os ésteres etílicos, como o acetato de etila por exemplo, e em menores concentrações, os ésteres de álcoois superiores, como o acetato de isoamila (Suomalainen, 1981).

\subsubsection{Compostos carbonilicos}

\subsubsection{Dicetonas vicinais}

No meio em fermentação a concentração de dicetonas como o diacetil e 2,3pentanodiona é praticamente zero, o que indica que elas são consumidas tão rápido quanto produzidas. Quando as leveduras são removidas do meio fermentativo, esta concentração aumenta a um valor relativamente alto, o qual decresce quando a levedura é readicionada. Consequentemente, entende-se que diacetil é formado por quebra expontânea do $\alpha$ - 
acetolactato, sintetizado pela levedura e transferido ao meio. Por analogia, 2,3-pentanodiona poderia ser formada à partir de $\alpha$-cetohidroxibutirato. A reação que promove tal quebra é a descarboxilação oxidativa expontânea ( Suomalainen e Nykänen, 1972 ).

As dicetonas podem ser produzidas também por contaminantes, como Pediococcus e Aerobacter, hábeis na produção de diacetil ( Hough, 1982 ).

\subsubsection{Aldeídos}

Os aldeídos são altamente voláteis e possuem odor penetrante, afetando o aroma das bebidas alcoólicas (Suomalainen e Nykänen, 1972). São compostos intermediários da produção de álcoois, formados pela descarboxilação de oxo-ácidos ou pela oxidação dos respectivos álcoois (Rose, 1977). Alguns aldeídos, como o furfural, são formados por reação não enzímica entre carboidratos e proteínas, no início da reação de Maillard (Korolhkov², 1968 citado por COALBRA, 1983)

Em aguardentes de cana, Gutierrez (1990) observou teores de aldeídos totais entre 91 e $188 \mathrm{mg}$ de aldeído acético $.100 \mathrm{~mL}^{-1}$ de etanol.

\footnotetext{
${ }^{2}$ KOROLHKOV, I.I. Hidrólise por percolação das matérias-primas vegetais. Editora Indústria Florestal, Moscou, 1968 apud COALBRA. Cadernos COALBRA (1): produção de etanol da madeira. Brasília: COALBRA, 1983. 117p.
} 


\subsubsection{Acetais}

Os acetais são importantes componentes do "aroma" das bebidas alcoólicas, pois conferem-lhes os mais agradáveis aromas. São formados por reação de condensação entre aldeídos e álcoois (Suomalainen e Nykänen, 1972). Como exemplo de acetais presentes em bebidas alcoólicas, temos o dietil acetal e o diisoamil acetal.

Misselhorn $^{3}$ apud Rose (1977), afirma que os acetais não conferem substancial contribuição ao "aroma" do rum.

Em vinhos são encontrados em quantidades inferiores a $5 \mathrm{mg} \cdot \mathrm{L}^{-1}$ (Amerine et al., 1972).

\subsection{3. Ácidos orgânicos}

Os principais ácidos orgânicos que contribuem para o aroma das bebidas são os ácidos graxos. Sua biossíntese envolve um complexo enzimático ao qual acetil-CoA e malonil-CoA estão acopladas. Este complexo liga os intermediários até a formação de ácido graxo saturado, que pode ser reintegrado ao ciclo para a formação de ácidos graxos de cadeias longas. $\mathrm{O}$ ácido acético é quantitativamente o mais importante dos ácidos graxos no "whisky", totalizando 50 a 90\% da acidez volátil, seguido pelos ácidos cáprico (20 a 45\%), caprilico, láurico, capróico, isobutírico e isovalérico (Suomalainen e Nykänen, 1972).

\footnotetext{
${ }^{3}$ MISSELHORN, K. Annales de technologie agricole, Paris, v. 24, p.371 apud ROSE, A.H. Economic microbiology volume 1: alcoholic beverages. London: Academic Press, 1977. 760p.
} 
Em presença de contaminação bacteriana, os níveis de ácidos graxos podem se elevar, comprometendo o aroma do produto final, como no caso dos acidentes fermentativos com Propyonibacterium e Acetobacter (Margalith e Schwartz, 1970).

\subsection{4. Álcoois}

O álcool encontrado em maiores concentrações em bebidas alcoólicas é, redundantemente, o etanol. Porém, sua contribuição direta para o "bouquet" de determinada bebida alcoólica é limitada pelo seu elevado limiar de detecção. Já os álcoois superiores contribuem diretamente para o aroma, devido as variações nas proporções e aos seus odores característicos, aos quais somos muito mais sensiveis que ao do etanol (Margalith e Schwartz, 1970).

Os álcoois superiores são formados por desvio do metabolismo dos aminoácidos, no qual determinado cetoácido envolvido é descarboxilado a aldeído e posteriormente reduzido a álcool superior (Suomalainen e Nykänen, 1972). Compreendem principalmente os álcoois amilico, propilico e seus isômeros (Amerine et al., 1972).

Em vinhos são encontradas concentrações que variam de 140 a 420 mg de

álcoois superiores . $\mathrm{L}^{-1}$, e em "brandies", de 100 a $1270 \mathrm{mg} . \mathrm{L}^{-1}$ (Amerine et al., 1972).

Utilizando meio sintético, Giudici e colaboradores (1990) verificaram que as leveduras $\mathrm{H}_{2} \mathrm{~S}$ negativas produziram maiores concentrações de n-Propanol, o que foi posteriormente confirmado em fermentação de mostos de uvas, nos quais uma linhagem de levedura $\mathrm{H}_{2} \mathrm{~S}$ negativa produziu de 190 (variedade de uva 'Pinot") a $316 \mathrm{mg}$ de n-Propanol . $\mathrm{L}^{-1}$ (variedade "Chardonnay") (Giudici e colaboradores, 1993). 
Em caldo de cana fermentado, Nóbrega (1994) observou a concentração de $21,5 \mathrm{mg}$ de álcool isoamilico . $\mathrm{L}^{-1}$.

No ensaio de Zee e colaboradores (1984), as frações "brandy" do destilado de vinho continham de 1190 a $3240 \mathrm{mg}$ de álcoois superiores. $\mathrm{L}^{-1}$, segundo a variedade de uva empregada. Associando os teores destes compostos com a qualidade sensorial, observaram que as bebidas com maiores teores de álcoois superiores apresentavam melhor qualidade sensorial, sendo o oposto verificado por Onishi et. al. ${ }^{4}$ citado pelos mesmos autores. Por outro lado, os autores verificaram que os "brandies" de mais baixa qualidade sensorial possuiam maiores teores de ésteres e de acetaldeído, com exceção de um "brandy", ao qual os autores atribuíram a qualidade sensorial deste a outros componentes não identificados ou a "outros fatores".

Ramsay e Berry (1984) verificaram a maior formação de álcoois superiores $\left(346 \mathrm{mg} \cdot \mathrm{L}^{-1}\right)$ a $30^{\circ} \mathrm{C}$, em fermentação de mosto de malte para a fabricação de "whisky", em temperaturas que variaram de 20 a $35^{\circ} \mathrm{C}$.

Segundo Rose (1977), "bourbons" e "whiskies" escoceses são os mais ricos em álcoois superiores, podendo possuir até $2000 \mathrm{mg}$. $\mathrm{L}^{-1}$.

Gutierrez (1990) observou concentrações de álcoois superiores em aguardentes de cana que variavam de 2192 a $3688 \mathrm{mg} .100 \mathrm{~mL}^{-1}$ de etanol.

${ }^{4}$ ONISHI, M.; CROWELL, E.A.; GUYMON, J.F. American Journal of Enology and Viticulture, v.29, p.54, 1978. apud ZEE, J.A. Comparative composition of fusel oils in brandies made from six grape varieties and their relationship with sensory analysis. Lebensmittel-Wissenchaft und Technologie, n.17, p. 54-9, 1984. 


\subsubsection{Compostos fenólicos}

Os compostos fenólicos altamente voláteis são produridos pela

descarboxilação térmica dos ácidos p-cumárico e ferúlico, constituintes da matéria-prima. Leveduras e bactérias também podem descarboxilar estes ácidos. Deve-se também considerar que os compostos fenólicos podem ser dissolvidos dos tonéis de madeira, durante o envelhecimento de bebidas destiladas (Suomalainen e Nykänen, 1972).

\subsubsection{Compostos sulfurados}

Em função de seus odores desagradáveis, pequenas concentrações podem prejudicar o aroma das bebidas (Suomalainen e Nykänen, 1972).

O valor limiar de sensibilidade para a metil-mercaptana, por exemplo, situase em torno de 0,02 ppb em água (Hough, 1982).

Tais compostos são produzidos pela degradação de aminoácidos sulfurados, que pode ser efetuada pelo metabolismo microbiano ou pelo aquecimento exigido em alguns processos de produção de bebidas alcoólicas. 


\section{METODOLOGIA}

O experimento foi conduzido nas dependências do Departamento de Ciência e Tecnologia Agroindustrial da Escola Superior de Agricultura "Luiz de Queiroz" da Universidade de São Paulo, em Piracicaba - São Paulo.

Consistiu basicamente na montagem de três ensaios, cada um utilizando uma diferente linhagem de levedura do gênero Saccharomyces cerevisiae.

\subsection{Matéria-prima}

Foi utilizada cana-de-açúcar da variedade RB-785148 como matériaprima para nosso ensaio.

Imediatamente após o corte, a superficie dos colmos foi limpa em escova metálica rotativa montada sobre uma bancada metálica, acionada por motor elétrico, com a finalidade de se obter caldo límpido, facilitando assim o tratamento de clarificação, necessário para a otimização das determinações espectrofotométricas de massa celular, durante os experimentos. 


\subsection{Meios de cultura}

A realização dos experimentos envolveu a utilização de diferentes meios de cultura, descritos a seguir.

\subsubsection{Meios de manutenção e de propagação inicial dos microrganismos}

Para a manutenção e propagação inicial de microrganismos, foram utilizados os seguintes meios de cultura:

- "Yeast extract peptone dextrose" (YEPD), de composição:

Extrato de levedura..........................1\%

Peptona..........................................1\%

Glicose........................................2\%

- "Yeast extract peptone dextrose agar" (YEPDA), de composição:

Extrato de levedura.........................1\%

Peptona........................................1\%

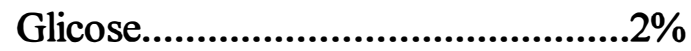

Agar..........................................1,5\% 
4.2.2. Meio para a seleção da linhagem não produtora de sulfeto de hidrogênio

Foi utilizado o meio diferencial "Bacto Bismuth Sulfite Agar" na seleção da linhagem não produtora de sulfeto de hidrogênio, com a seguinte composição $\left(\mathrm{g} . \mathrm{L}^{-1}\right)$ :

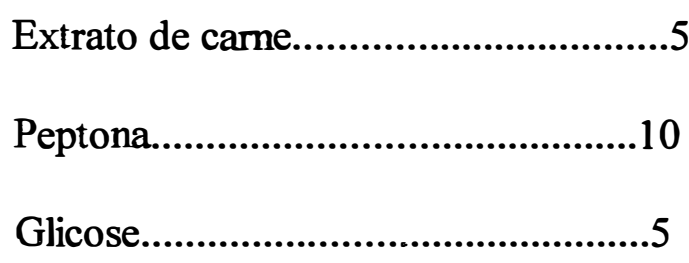

Fosfato dissódico.............................4

Sulfato ferroso...............................0,39

Sulfeto de bismuto...........................8

Agar............................................20

Verde brilhante................................0,025

4.2.3. Meio para a propagação final dos microrganismos e realização do experimento

A partir da matéria-prima descrita no ítem 4.1., foi elaborado o meio de propagação final dos microrganismos, segundo a metodologia descrita nos ítens a seguir. 


\subsubsection{Extração do caldo}

A extração do caldo foi efetuada em um único terno de moenda, utilizando-se os colmos inteiros provindos da operação de limpeza superficial. Os colmos foram submetidos a três moagens consecutivas, sob pressão do cilindro-mestre de $1000 \mathrm{Kgf.cm}^{-2}$, sem embebição.

\subsubsection{Preparo do mosto}

Foram preparados $45 \mathrm{~L}$ de mosto, que serviu como meio para a propagação final dos microrganismos e realização do experimento, a 14 brix para cada ensaio, sendo divididos em três fermentadores de $15 \mathrm{~L}$ de volume útil, segundo a seguinte marcha de trabalho:

O bagacilho proveniente da moagem foi removido do caldo extraido por peneiragem e, logo em seguida, procedeu-se o tratamento de clarificação, conseguido pelo aquecimento do caldo até a ebulição, mantida por 5 minutos. Decorrido este tempo, deixou-se o caldo em repouso a temperatura ambiente por cerca de 12 horas para que ocorresse a decantação da proteína coagulada. $\mathrm{O}$ sobrenadante foi então filtrado em Celite 503 e algodão, acondicionado em balões de $6 \mathrm{~L}$, esterilizado a $121{ }^{\circ} \mathrm{C}$ por 15 minutos e assim armazenado por período não superior a 24 horas. 
O processo de clarificação proporcionou um produto límpido, desprovido de sedimentos quando submetido à centrifugação, características necessárias às determinações espectrofotométricas de matéria seca.

Em cada ensaio, o conteúdo dos balões foi aleatoriamente distribuído pelos três fermentadores e, em cada fermentador, foram efetuadas as correções de brix e volume finais.

O caldo assim tratado foi utilizado como mosto, após a suplementação adequada, tanto para a propagação final do inóculo, quanto para a realização do experimento. A suplementação consistiu em se adicionar ao caldo diluído (Barone, 1994):

- Sulfato de amônio $\left(\left(\mathrm{NH}_{4}\right)_{2} \mathrm{SO}_{4}\right): 1,667$ g.L $\mathrm{L}^{-1}$;

- Fosfato de potássio $\left(\mathrm{KH}_{2} \mathrm{PO}_{4}\right): 0,528 \mathrm{~g} \cdot \mathrm{L}^{-1}$;

- Cloreto de magnésio ( $\mathrm{MgCl}$ ): 0,195 g. $\mathrm{L}^{-1}$.

\subsection{Microrganismos}

Foram utilizadas três linhagens de Saccharomyces cerevisiae, sendo duas floculantes, das quais uma não produtora de sulfeto de hidrogênio e uma isolada a partir de fermento prensado comercial, aqui denominada pulverulenta, pelo aspecto em fermentação.

Os microrganismos foram multiplicados a partir de tubos contendo as linhagens puras mantidas em meio "Yeast Peptone Dextrose Agar" (YPDA) inclinado, cuja composição encontra-se no ítem 4.2.1. 


\subsubsection{Seleção da linhagem não produtora de sulfeto de hidrogênio $\left(\bar{H}_{2} \mathrm{~S}\right)$}

Para a seleção da levedura não produtora de $\mathrm{H}_{2} \mathrm{~S}$ foi utilizado meio diferencial "Bacto Bismuth Sulfite Agar" (BSA), conforme metodologia proposta por Zambonelli (1964). Este meio de cultura promove a formação de colônias brancas, quando o material microbiano que às deu orígem não produz sulfeto de hidrogênio. A produção de sulfeto de hidrogênio pelo microrganismo é verificada pelo crescimento de colônias escuras, devido à reação deste composto com o sulfato ferroso presente no meio, formando o sal negro sulfeto de ferro. A composição deste meio consta do ítem 4.2.2.

A partir de 50 tubos de YPDA inclinado fornecidos pela micoteca do Departamento, contendo cada um uma diferente linhagem de Saccharomyces cerevisiae, foram efetuadas repicagens para tubos contendo meio líquido YPD ( ver ítem 4.2.1.), os quais foram incubados a $30^{\circ} \mathrm{C}$ por $24 \mathrm{~h}$. Destes, foram inoculadas as placas de BSA com o uso de replicador múltiplo de 25 agulhas, conseguindo-se inocular 25 linhagens por placa, simetricamente distribuídas na superficie do meio de cultura. Cada linhagem de levedura foi inoculada em triplicata. Este material foi incubado a $30^{\circ} \mathrm{C}$ por um período de 24 h, após o qual pode ser verificado o crescimento das colônias.

Pelo surgimento de uma colônia de coloração branca, repetiu-se a multiplicação da respectiva linhagem em meio YPD líquido e a inoculação em triplicata 
sobre o meio diferencial, desta vez estriando-se, com alça de Henle, apenas uma linhagem por placa, para teste confirmativo.

\subsubsection{Propagação dos microrganismos}

A partir do material microbiano cultivado em meio YPDA, foram feitas inoculações em 9 erlenmeyers de $500 \mathrm{~mL}$ contendo $200 \mathrm{~mL}$ de meio YPD, através de alça de Henle, utilizando-se três alças por frasco. Tais frascos foram incubados em "shaker" modelo DUBNOFF MA-095, fabricado pela MARCONI, a $30{ }^{\circ} \mathrm{C}$ por $24 \mathrm{~h}$. Decorrido este tempo, o conteúdo dos erlenmeyers foi centrifugado e o fermento precipitado ressuspenso em água destilada por duas vezes consecutivas, com a finalidade de separação do material celular e eliminação de metabólitos.

A massa celular obtida foi então submetida ao processo final de multiplicação, efetuado em 2 fermentadores de 15 L, sob 200rpm de velocidade do eixo do agitador e a $30^{\circ} \mathrm{C}$, até que se atingisse quantidade celular suficiente para a inoculação no experimento de fermentação. $O$ meio utilizado para esta finalidade foi o mosto clarificado e esterilizado, anteriormente descrito. Para a separação e purificação do material celular, procedeu-se centrifugações e ressuspensões em água destilada do precipitado por três vezes consecutivas, em centrifuga marca International Refrigerated Centrifuge, modelo PR-2, a $900 \mathrm{G}$ e $10{ }^{\circ} \mathrm{C}$. Sobre o material celular assim obtido foi efetuada a determinação de matéria-seca, pelo método de secagem em forno de microondas até ser atingido peso constante (Sakai et al., 1990), para o cálculo da massa 
de inóculo fresco a ser adicionado a cada fermentador, necessária para se obter a taxa de inoculação de $4 \mathrm{~g}$ de matéria seca. $\mathrm{L}^{-1}$ de mosto.

\subsection{Fermentação}

No que se refere à fermentação, foram montados três ensaios, segundo o inóculo utilizado:

Ensaio LF: efetuado com a linhagem de levedura floculante;

Ensaio IZ: efetuado com a linhagem IZ-987, floculante e não produtora de gás sulfidrico;

Ensaio FP: efetuado com a linhagem de levedura pulverulenta isolada de fermento prensado comercial.

As fermentações transcorreram sob o sistema de batelada simples em fermentadores com capacidade útil para 15 litros, dotados de sistema de controle de temperatura e de agitação (Barone, 1994).

Cada ensaio foi montado em três fermentadores contendo $15 \mathrm{~L}$ de mosto a 14 brix, conforme descrito no ítem 4.2.3.2.

A temperatura de fermentação e a rotação das palhetas agitadoras foram mantidas em $30 \pm 1^{\circ} \mathrm{C}$ e $200 \mathrm{rpm}$, respectivamente.

A cada 4 horas foram retiradas amostras de $40 \mathrm{~mL}$, destinadas às determinações analíticas para o acompanhamento da cinética fermentativa. As determinações foram: atenuação de brix, açúcares redutores totais, teor alcoólico, após 
destilação quantitativa por arraste de vapor de $25 \mathrm{~mL}$ de amostra (Barone, 1994), e concentração de leveduras.

Alíquotas de $4 \mathrm{~mL}$ provenientes das amostras destiladas de mosto em fermentação para a determinação do teor alcoólico, foram submetidas às determinações cromatográficas.

O final da fermentação foi determinado a partir da estabilização da produção de etanol, verificada pela leitura de dois valores iguais e consecutivos de teor alcoólico, em período de 2 horas entre amostragens de $25 \mathrm{~mL}$, efetuadas a partir do momento em que se observasse o valor de 2 brix no mosto em fermentação.

\subsection{Destilação}

Procedeu-se a destilação dos vinhos em coluna tipo Besnard-Estève, ilustrada na figura 1 , dotada de aquecimento elétrico controlado por reostato, o que possibilitou a padronização do fornecimento de energia. Foram utilizados $14 \mathrm{~L}$ de vinho, decantado por período mínimo de 2 horas, para as destilações. $\mathrm{O}$ destilado foi recolhido em frações de $200 \mathrm{~mL}$ para posterior determinação das frações que comporiam a aguardente, segundo o perfil da curva de acidez das mesmas. Destilou-se o vinho até que se atingisse a temperatura de $98^{\circ} \mathrm{C}$ na bainha do último corpo do tronco de destilação. 
1-Caldeira

2-Tronco de destilaçāo

3-Termômetro

4-Condensador (serpentina)

5-Saída de destilado

6-Entrada de vinho

7-Descarga de vinhoca

8-Reostato

9-Respiro
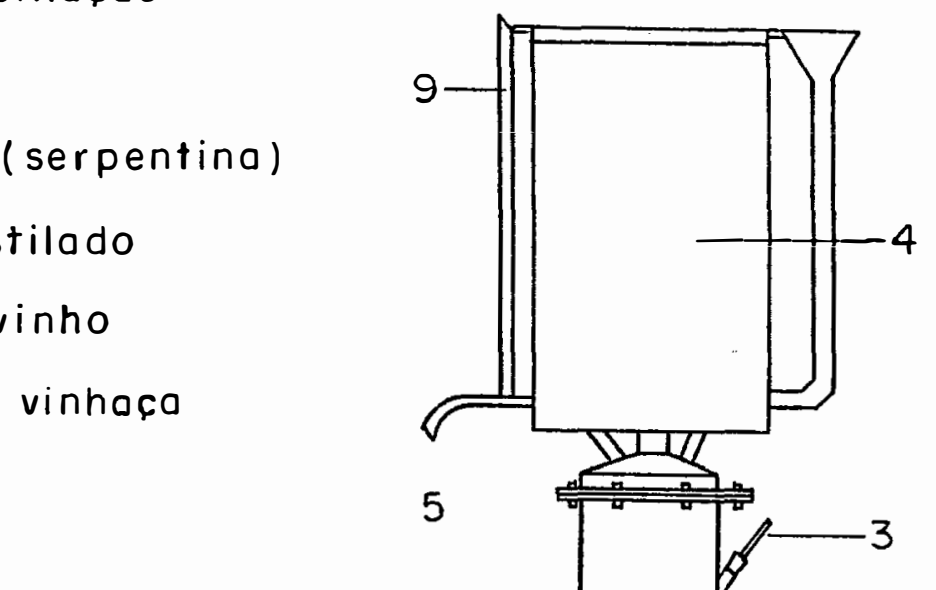

5
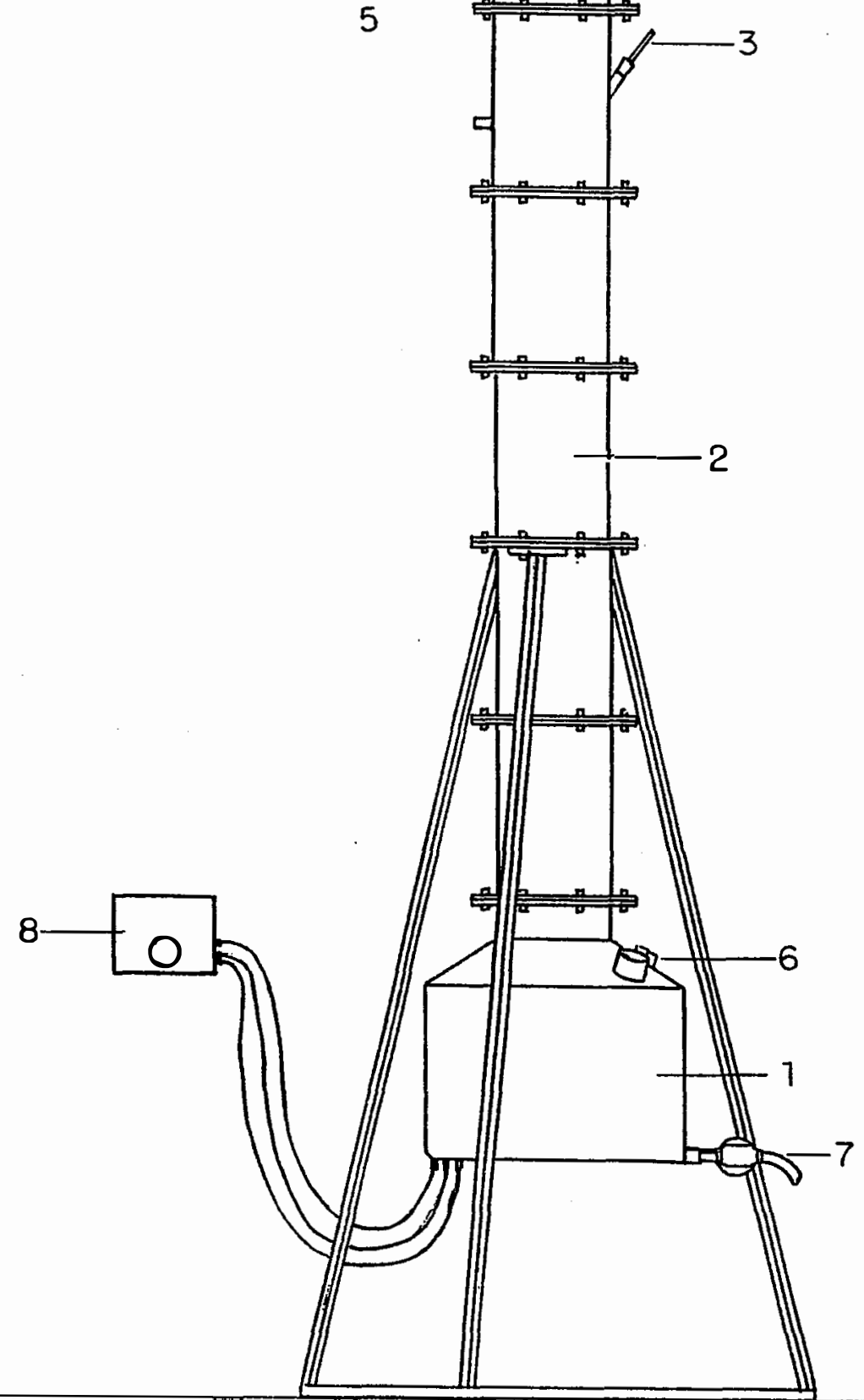

Figura 1-Conjunto de destilaçāo tipo Besnard-Esteve 
Sobre a curva de acidez do destilado no decorrer da operação de destilação obtida por Lafon et. al. ${ }^{1}$, citados por Amerine e colaboradores (1972) e recentemente por Boza (1996), verificou-se a ocorrência de alguns pontos de inflexão. Observou-se um ponto particular, que determinava a última mudança de concavidade da curva, onde se observava, daí em diante, a mudança no comportamento do aumento da acidez. Estabeleceu-se então que a aguardente seria composta pelas frações destiladas até este ponto, justamente o último ponto de mudança de concavidade da curva de acidez em função das frações de destilado.

\subsection{Aguardentes}

As aguardentes foram elaboradas com as frações de destilado, escolhidas conforme o critério pré-estabelecido no ítem 4.5., obtidas das três fermentações de cada linhagem, para se obter volume suficiente de amostras para a análise sensorial. As aguardentes assim obtidas foram padronizadas a $40 \%\left(\mathrm{v} . \mathrm{v}^{-1}\right)$ de etanol, por diluição com água mineral comercial.

Denominou-se caudas ou águas fracas à mistura das frações de destilado que não entraram na composição das aguardentes, que foram misturadas e também submetidas às análises físico-químicas.

\footnotetext{
${ }^{1}$ LAFON, R; LAFON, J.; COUILLAUD, P. Le cognac; sa distillation. Paris: J.B. Baillière et Fils, 1964. apud AMERINE, M.A.; BERG, H.W.; CRUESS, W.V. The technology of wine making. Westport, AVI Publishing Company. $3^{\text {rd }}$ ed. , 1972, 802p.
} 


\subsection{Determinações analíticas}

$\mathrm{Na}$ tentativa de contribuir para a uniformização das unidades utilizadas nos trabalhos de pesquisa em tecnologia, foi utilizado neste estudo o sistema adotado por Präve e colaboradores (1987).

\subsubsection{Determinações físico-químicas}

- brix areométrico (COPERSUCAR, 1987), efetuada sobre caldos tratados, mostos e mostos em fermentação;

- Açúcares redutores totais (ART), através do método espectrofotométrico de Somogyi \& Nelson, segundo Neish (1952), utilizando-se espectrofotômetro digital COLEMAN modelo SP35-D, efetuada sobre os mostos e mostos em fermentação;

- Concentração de leveduras nos mostos em fermentação e dos vinhos decantados, pelo método espectrofotométrico proposto por Stratford \& Keenan (1988);

- Teor alcoólico, através da conversão por tabela apropriada, do valor de densidade obtida pelo densímeto digital A. PAAR modelo DmA-45, efetuada nos mostos em fermentação após destilação por arraste (Barone, 1994), nas frações do destilado, nas aguardentes e nas águas fracas;

- Acidez total dos vinhos decantados, das frações do destilado, das aguardentes e das águas fracas (INSTITUTO ADOLFO LUTZ 1985); 
- Acidez volátil (INSTITUTO ADOLFO LUTZ, 1985), nas aguardentes e nas águas fracas;

- Acidez fixa (INSTITUTO ADOLFO LUTZ, 1985), nas aguardentes e nas águas fracas;

- pH (INSTITUTO ADOLFO LUTZ, 1985), utilizando-se potenciômetro digital DIGIMED modelo DMPH-2 nas determinações sobre mosto e vinho;

- Cobre nas aguardentes e nas águas fracas, segundo Jacintho, 1967;

- Extrato seco das aguardentes e das águas fracas (INSTITUTO ADOLFO LUTZ, 1985).

\subsubsection{Determinações cromatográficas}

Alíquotas das amostras periódicas retiradas do mosto em fermentação foram submetidas, após destilação por arraste, à cromatografia para a detenminação de aldeídos totais, acetona, ésteres totais, álcoois Metílico, n-Propílico, n-Butílico, i-Butílico, n-Amílico e i-Amílico + Amilico opticamente ativo. 
Utilizou-se o método de injeção direta nas determinações cromatográficas efetuadas sobre as aguardentes e águas fracas.

Foi utilizado cromatógrafo a gás $\mathrm{CG}$ modelo $37 \mathrm{D}$, com detector de ionização de chama, com processador/integrador eletrônico modelo CG 200.

As condições de análise foram:

- Coluna: PAAC 3334 de aço inoxidável, com 3 m de comprimento e $1 / 8^{\prime \prime}$ de diâmetro, à temperatura de $95^{\circ} \mathrm{C}$;

- Fase estacionária: Hallcomid M-18 e Carbowax 3000;

- Fase móvel: nitrogênio ultra-puro;

- Detector: temperatura de $250{ }^{\circ} \mathrm{C}$, utilizando hidrogênio ultra-puro e ar sintético como gases auxiliares;

- Injetor: temperatura de $150^{\circ} \mathrm{C}$;

O método utilizado foi o de padronização externa, com injeção de $3 \mu \mathrm{L}$ de amostra.

\subsection{Cálculos dos parâmetros de fermentação}

Com os dados de brix e de açúcares redutores totais do mosto, calculouse a pureza em açúcares segundo a equação:

$$
\mathrm{P}_{\mathrm{ART}}=\frac{\mathrm{ART}}{\text { brix }} \times 100 \text {, onde: }
$$


$\mathrm{P}_{\mathrm{ART}}=$ Pureza em açúcares redutores totais, expressa em porcentagem

$\left(\right.$ p. $\left.v^{-1}\right)$;

$\mathrm{ART}=$ Açúcares redutores totais, expressos em g de glicose $.100 \mathrm{~mL}^{-1}$;

brix $=$ Sólidos solúveis, expressos em porcentagem $\left(\mathrm{p} \cdot \mathrm{p}^{-1}\right)$.

A partir dos resultados das determinações analíticas sobre mosto e mosto em

fermentação, procedeu-se os cálculos dos seguintes parâmetros de fermentação:

- Concentração celular produzida, segundo a equação:

$\mathrm{X}=\mathrm{X}_{\mathrm{f}}-\mathrm{X}_{0}$, onde:

$\mathrm{X}=$ concentração celular produzida $\left(\mathrm{g}\right.$ matéria-seca. $\left.\mathrm{L}^{-1}\right)$;

$\mathrm{X}_{\mathrm{f}}=$ Concentração celular final ( $\mathrm{g}$ matéria-seca $\left.\cdot \mathrm{L}^{-1}\right)$;

$\mathrm{X}_{0}=$ Concentração celular inicial (g matéria-seca $\left.\cdot \mathrm{L}^{-1}\right)$.

- Porcentagem de células produzidas $\left(\mathrm{X}_{\%}\right)$, segundo a equação:

$\mathrm{X}_{\%}=\frac{\mathrm{X}}{\mathrm{X}_{\mathrm{f}}} \times 100$

- Açúcar consumido;

$\mathrm{S}=-\left(\mathrm{S}_{\mathrm{f}}-\mathrm{S}_{0}\right)$, onde:

$\mathrm{S}=$ açúcar consumido $\left(\mathrm{g}\right.$ de glicose $\left.\cdot \mathrm{L}^{-1}\right)$

$\mathrm{S}_{\mathrm{f}}=$ concentração final de açúcares $\left(\mathrm{g}\right.$ de glicose. $\left.\mathrm{L}^{-1}\right)$;

$\mathrm{S}_{0}=$ concentração inicial de açúcares $\left(\mathrm{g}\right.$ de glicose $\left.\cdot \mathrm{L}^{-1}\right)$.

- Fator conversão de substrato em biomassa, segundo a equação:

$\mathrm{Y}_{\frac{\mathrm{X}}{\mathrm{S}}}=\frac{\mathrm{X}}{\mathrm{S}}$, onde: 
$Y_{\frac{X}{S}}=$ fator de conversão de substrato em biomassa.

- Etanol produzido:

$\mathrm{P}=\mathrm{P}_{\mathrm{f}}-\mathrm{P}_{\mathrm{i}}$, onde:

$\mathrm{P}=$ etanol produzido $\left(\mathrm{g} \cdot \mathrm{L}^{-1}\right)$;

$\mathrm{P}_{\mathrm{f}}=$ concentração de etanol final $\left(\mathrm{g} \cdot \mathrm{L}^{-1}\right)$;

$P_{i}=$ concentração de etanol inicial $\left(g . L^{-1}\right)$.

- Fator de conversão de substrato em etanol:

$$
\mathrm{Y}_{\overline{\mathrm{P}}}=\frac{\mathrm{P}}{\mathrm{S}}, \text { onde }
$$

$\mathrm{Y}_{\frac{\mathrm{p}}{\mathrm{S}}}=$ Fator de conversão de substrato em etanol $\left(\mathrm{g} \cdot \mathrm{g}^{1}\right)$.

- Produtividade de etanol:

$\mathrm{PR}=\frac{\mathrm{P}}{\mathrm{t}}$, onde:

$\mathrm{PR}=$ produtividade de etanol $\left(\mathrm{g} \cdot \mathrm{L}^{-1} \cdot \mathrm{h}^{-1}\right)$,

$\mathrm{t}=$ tempo de fermentação $(\mathrm{h})$.

- Eficiência de fermentação $\left(\eta_{\mathrm{P}(\%)}\right)$, com base no rendimento teórico proveniente da equação de Gay-Lussac (51,1 g etanol . 100g glicose $\left.{ }^{-1}\right)$ :

$$
\eta_{P(\%)}=\frac{\frac{Y_{P}}{S} \times 100}{51,1}
$$

- Velocidade específica máxima de crescimento, segundo o coeficiente angular da equação da reta do logarítmo neperiano da concentração de leveduras em função 
do tempo de fermentação, correspondente à fase exponencial de crescimento, determinada por regressão linear (Pirt, 1985):

$$
\begin{aligned}
& \ln [\mathrm{X}]=\mu . \mathrm{t}+\mathrm{b} \text {, onde: } \\
& \ln [\mathrm{X}]=\text { logarítmo neperiano da concentração de leveduras na fase }
\end{aligned}
$$

exponencial de crescimento;

$$
\begin{aligned}
& \mu=\text { velocidade específica máxima de crescimento }\left(\mathrm{h}^{-1}\right) ; \\
& \mathrm{t}=\text { tempo }(\mathrm{h}) ; \\
& \mathrm{b}=\text { coeficiente linear da equação do logarítmo da concentração de leveduras }
\end{aligned}
$$

em função do tempo de fermentação, na fase exponencial de crescimento.

\subsection{Análise sensorial}

Utilizou-se o teste triangular (Mori, 1992) para a seleção do painel de degustadores. Assim foram selecionadas 7 pessoas, dentre 30 participantes, capazes de diferenciar, ao nivel de 5\% de probabilidade, duas amostras de aguardente, sendo uma de produção da planta piloto do Departamento e outra comercial não adoçada, numa batelada de 5 testes.

As aguardentes foram submetidas aos testes sensoriais:

- Teste de diferença, através do teste triangular, segundo Mori (1992);

- Teste de preferência, através do teste pareado (Mori, 1992).

Os resultados foram interpretados, para se verificar o nível de significância, segundo Roessler (1978). 


\section{RESULTADOS E DISCUSSÃO}

\subsection{Seleção da linhagem não produtora de $\mathrm{H}_{2} \mathrm{~S}$}

Das 50 linhagens fornecidas pela micoteca do Departamento, apenas a IZ-987 formou colônias brancas, indicando a não produção de gás sulfidrico, tanto no teste preliminar quanto no teste comprobativo, sendo portanto eleita uma das linhagens a ser utilizada no experimento.

A frequência de ocorrência por nós observada (2\%) é a mesma obtida no trabalho de Zambonelli (1964), em linhagens de interêsse enológico.

\subsection{Mosto}

Os mostos preparados a partir dos caldos tratados e suplementados apresentaram as características ilustradas na tabela 1:

Considerando que o mosto foi tratado parceladamente e não foi homogeneizado ao ser distribuído nas dornas, já se esperava variações quanto aos parâmetros estudados. 
Mesmo tomando o cuidado de se padronizar ao máximo as operações de clarificação, isto é, fervura, decantação e filtração, observou-se que os valores de pureza em açúcares redutores totais em relação aos sólidos solúveis variaram, mostrando a dificuldade de se obter um mosto homogêneo dentro das condições de matéria-prima utilizada e de tratamento efetuado.

Tabela 1 - Características dos mostos utilizados nos ensaios.

\begin{tabular}{lcccccc}
\hline Linhagens & & brix & $\begin{array}{c}\mathrm{AT} \\
\left(\mathrm{g} .100 \mathrm{~mL}^{-1}\right)\end{array}$ & $\left.\left.\begin{array}{c}\text { Pureza } \\
(\mathrm{AT} . \text { brix }\end{array} \mathrm{x} 100\right)^{-1}\right)$ & $\begin{array}{c}\mathrm{V} \\
\mathrm{L})\end{array}$ & $\mathrm{pH}$ \\
\hline & Média & 14,0 & 12,91 & 92,19 & 15 & 4,95 \\
$\mathrm{LF}$ & desv. padrão $=\mathrm{s}$ & 0 & 0,56 & 4,03 & 0 & 0,07 \\
\hline & Média & 14,0 & 13,11 & 93,88 & 15 & 4,94 \\
$\mathrm{IZ}-987$ & $\mathrm{~s}$ & 0 & 0,28 & 2,04 & 0 & 0,08 \\
\hline & Média & 14,0 & 12,85 & 91,81 & 15 & 4,90 \\
$\mathrm{FP}$ & $\mathrm{S}$ & 0 & 0,21 & 1,50 & 0 & 0,03 \\
\hline
\end{tabular}

\subsection{Fermentação}

As três linhagens de levedura utilizadas para fermentar o caldo-de-cana, mostraram particularidades cujos resultados são apresentados e discutidos a seguir. 


\subsubsection{Cinética fermentativa}

A Tabela 2 resume os resultados obtidos das três fermentações.

Observou-se que a levedura floculante (LF) mostrou-se superior às demais, em termos de produtividade de etanol $\left(3,40 \mathrm{~g} \cdot \mathrm{L}^{-1} \cdot \mathrm{h}^{-1}\right)$, produzindo $54,51 \mathrm{~mL}$ de álcool. $\mathrm{L}^{-1}$ de vinho em apenas 16 horas.

Nota-se também que, esta levedura foi a que menos converteu açúcares redutores em álcool, frente aos valores de fator de conversão de substrato em etanol e de eficiência de fermentação obtidos. Observando-se os valores de porcentagem de células produzidas e do fator conversão de substrato em biomassa, verifica-se que esta levedura floculante utiliza o substrato mais eficientemente para a produção celular do que as outras linhagens em estudo.

A figura 2 ilustra o comportamento desta levedura no decorrer da fermentação.

A levedura IZ - 987 foi a que apresentou maiores valores de conversão de substrato em etanol e portanto de eficiência de fermentação. Porém, o tempo de fermentação de 20 horas diminuiu a produtividade de fermentação, embora fosse um comportamento esperado, visto tratar-se de uma linhagem mutante $\left(\mathrm{H}_{2} \mathrm{~S}\right.$ negativa). $\mathrm{O}$ acompanhamento cinético da fermentação efetuada por esta levedura encontra-se na figura 3. 


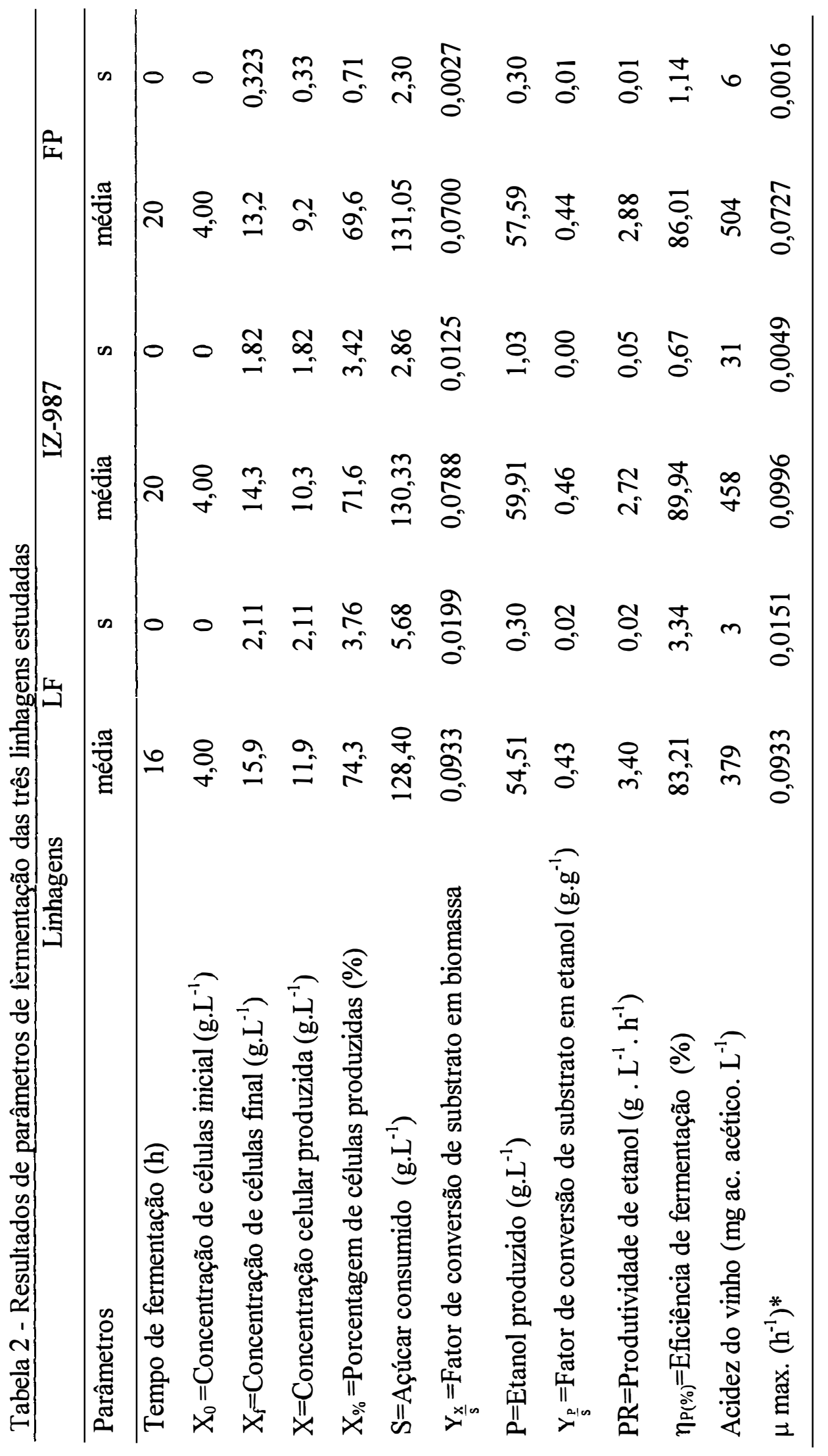


A linhagem de levedura obtida do fermento prensado comercial (FP), proporcionou menor produtividade de fermentação que a IZ - 987, devido ao menor teor de etanol produzido, conquanto os fatores de conversão de substrato em etanol $(0,44 \mathrm{~g}$ de etanol. $\mathrm{g}$ de glicose $\left.^{-1}\right)$ e de eficiência de fermentação $(86,00 \%)$ também fossem inferiores aos da IZ - $987\left(0,46 \mathrm{~g} \cdot \mathrm{g}^{-1}\right.$ e 89,94\%) e superiores aos da levedura floculante.

Neste caso, comparando-se estes resultados com os da levedura floculante, verifica-se que a maior produção de etanol da levedura FP foi responsável pelos melhores valores por esta obtidos. As variáveis estudadas desta levedura durante a fermentação encontram-se na figura 4.

Os resultados de produtividade de fermentação obtidos nos três tratamentos mostraram valores superiores aos obtidos por Nóbrega (1994), que obteve $2,20 \mathrm{~mL} . \mathrm{L}^{-1} \cdot \mathrm{h}$, na fermentação induzida, com valor de eficiência de fermentação de $86,3 \%$.

Parazzi (1995), testando 4 linhagens de leveduras, sendo uma pulverulenta, encontrou valores de produtividade que variaram de 2,85 a $4,16 \mathrm{~g} \cdot \mathrm{L}^{-1} \cdot \mathrm{h}^{-1}$, em caldo clarificado contendo em torno de $100 \mathrm{~g}$ de glicose. $\mathrm{L}^{-1}$ e $10 \mathrm{~g}$ de inóculo. $\mathrm{L}^{-1}$. Nos resultados expressos na tabela 2 , observa-se a variação de 2,72 (IZ) a $3,40 \mathrm{~g} \cdot \mathrm{L}^{-1} \cdot \mathrm{h}^{-1}$ (LF). Seu maior valor de fator de conversão de substrato em etanol foi de $0,43 \mathrm{~g} \cdot \mathrm{g}^{-1}$ para as leveduras floculantes, que se mostra idêntico ao tratamento LF e inferior aos demais, sendo de $0,38 \mathrm{~g} \cdot \mathrm{g}^{-1}$ o rendimento por ele obtido para a levedura não floculante. 


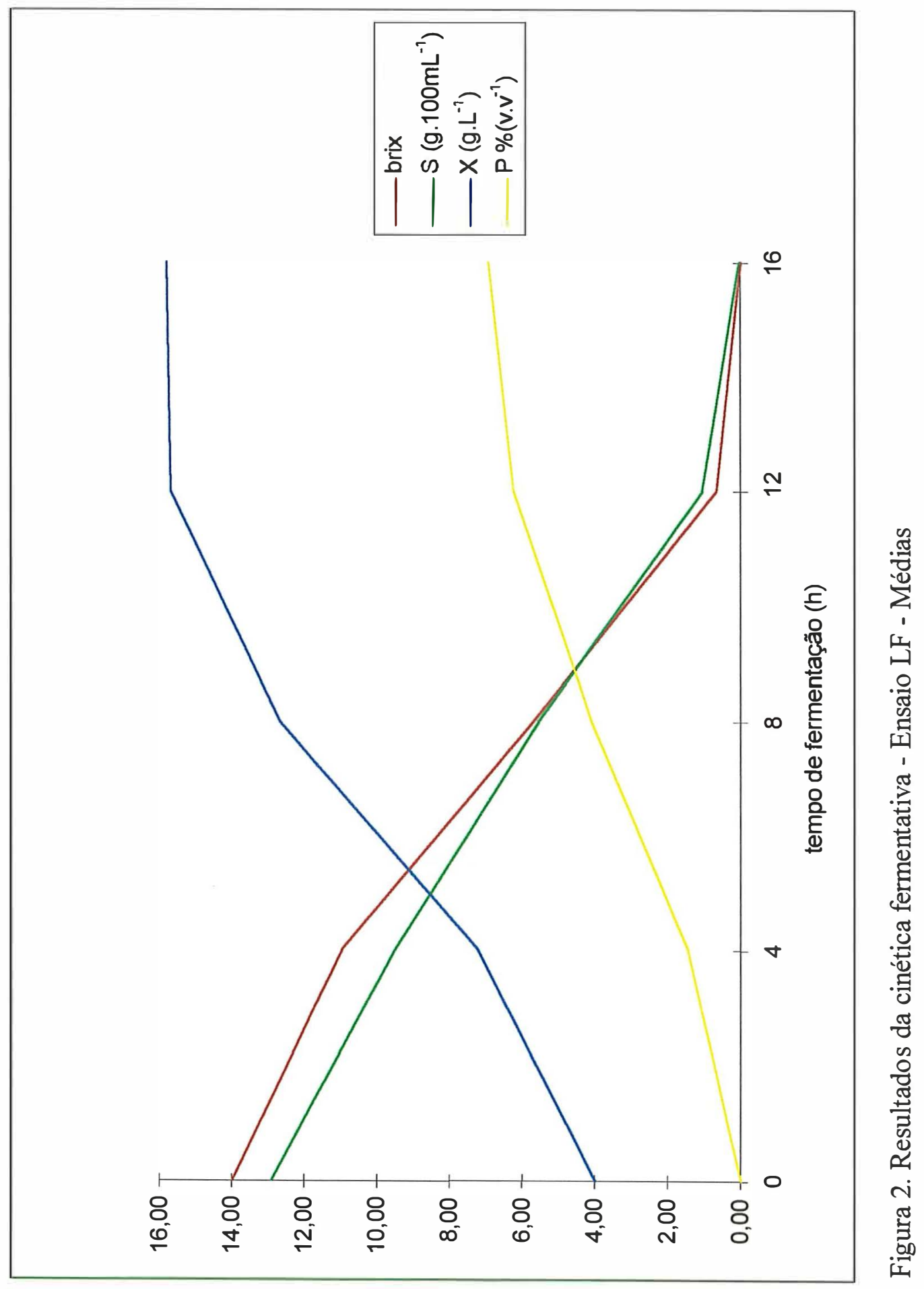




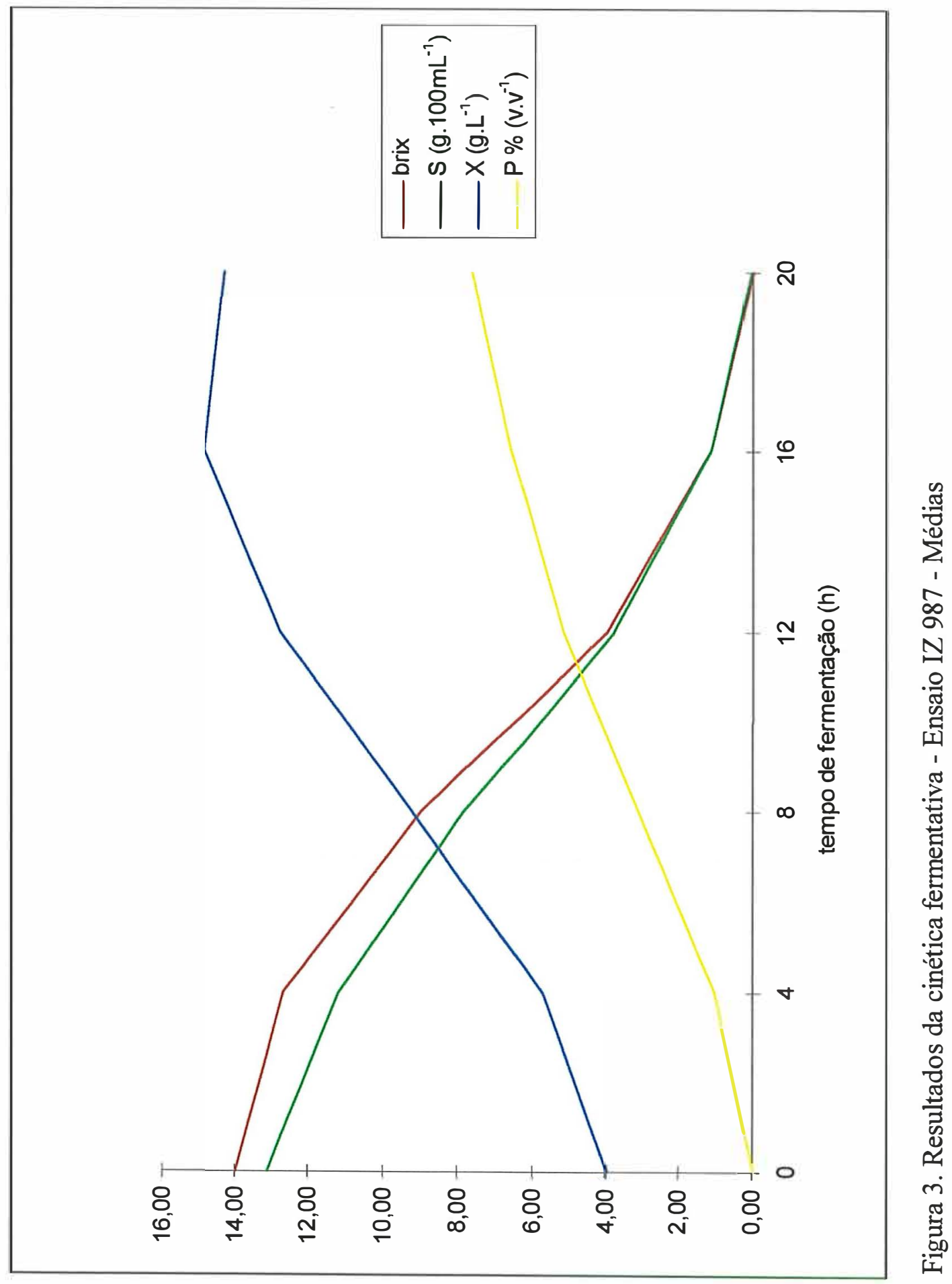




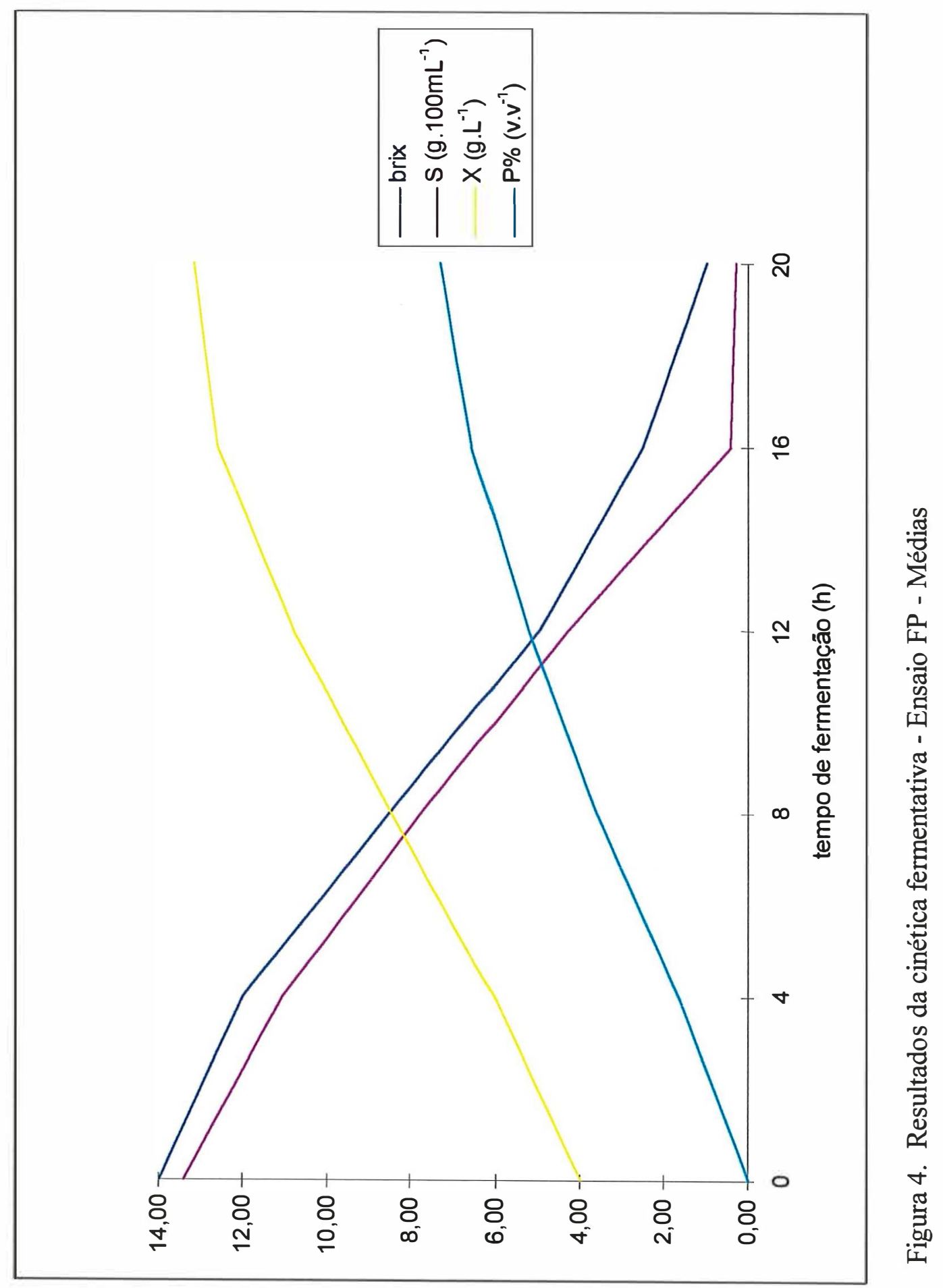


Quanto aos valores de velocidade específica de crescimento, nas condições em que foi montado o experimento e no intervalo considerado (4 a 12 horas de fermentação), foram obtidos: $0,0996 \mathrm{~h}^{-1}$ para o tratamento IZ, $0,0933 \mathrm{~h}^{-1}$ em LF e $0,0727 \mathrm{~h}^{-1}$ em FP, conforme consta na tabela 2. Tais resultados estão em conformidade com os calculados a partir dos dados de Parazzi (1995), que situam-se em torno de 0,03 (não floculante) e $0,13 \mathrm{~h}^{-1}$ (levedura floculante SI155/SL9).

O acompanhamento das variáveis de fermentação (atenuação de brix, consumo de açúcares, produção de massa celular e produção de álcool) dos três ensaios é também ilustrado no apêndice 1 .

\subsubsection{Análises cromatográficas do mosto em fermentação}

Os vinhos obtidos da fermentação pelas três linhagens utilizadas foram analisados cromatograficamente e estes apresentaram aldeídos, ésteres, n-Propanol, iButanol e álcool i-Amilico, conforme observado na tabela 3.

Tanto o tratamento LF quanto o IZ não produziram acetona, Metanol, nButanol nem álcool n-Amilico. Já no tratamento FP, foram detectados traços de acetona $\left(0,1 \mathrm{mg} \cdot 100 \mathrm{~mL}^{-1}\right)$ e Metanol ( $\left.1 \mathrm{mg} \cdot 100 \mathrm{~mL}^{-1}\right)$ em alguns momentos da fermentação. $\mathrm{O}$ metanol pode ter derivado da cana que pode conter matérias pécticas em pequenas quantidades e, quando hidrolisadas dariam orígem a este, extraído durante a destilação das amostras. 
A produção de álcoois superiores pode ter sido influenciada pela suplementação nitrogenada, responsável pelos valores relativamente baixos obtidos.

Tabela 3 - Resultados das determinações cromatográficas durante as fermentações nos diferentes tratamentos

\begin{tabular}{|c|c|c|c|c|c|c|c|c|c|c|c|}
\hline \multirow[t]{2}{*}{ Ensaio } & \multirow[b]{2}{*}{$t$ (h) } & \multicolumn{2}{|c|}{$\begin{array}{c}\text { Aldeídos } \\
\left(\mathrm{mg} . \mathrm{L}^{-1}\right) \\
\end{array}$} & \multicolumn{2}{|c|}{$\begin{array}{c}\text { Ésteres } \\
\left(\mathrm{mg} . \mathrm{L}^{-1}\right) \\
\end{array}$} & \multicolumn{2}{|c|}{$\begin{array}{l}\text { n-Propanol } \\
\text { (mg.L) }\end{array}$} & \multicolumn{2}{|c|}{$\begin{array}{l}\text { i-Butanol } \\
\left(\mathrm{mg} \cdot \mathrm{L}^{-1}\right)\end{array}$} & \multicolumn{2}{|c|}{$\begin{array}{l}\text { i-Amílico } \\
\left(\mathrm{mg} \cdot \mathrm{L}^{-1}\right)\end{array}$} \\
\hline & & média & $\mathrm{s}$ & média & $\mathrm{s}$ & média & $\mathrm{s}$ & média & $\mathrm{s}$ & média & $\mathrm{s}$ \\
\hline \multirow{5}{*}{ LF } & 0 & 0,0 & 0,0 & 0,0 & 0,0 & 0,0 & 0,0 & 0,0 & 0,0 & 0,0 & 0,0 \\
\hline & 4 & 12,1 & 3,6 & 2,1 & 1,5 & 17,0 & 3,5 & 6,6 & 0,4 & 11,0 & 1,8 \\
\hline & 8 & 12,8 & 1,6 & 1,0 & 0,8 & 19,6 & 1,6 & 15,9 & 0,9 & 32,9 & 0,6 \\
\hline & 12 & 19,8 & 2,3 & 3,1 & 0,3 & 19,9 & 1,2 & 24,5 & 1,3 & 51,4 & 0,9 \\
\hline & 16 & 12,4 & 5,4 & 5,5 & 0,4 & 27,4 & 11,8 & 28,2 & 1,1 & 62,7 & 1,1 \\
\hline \multirow{6}{*}{ IZ } & 0 & 0,0 & 0,0 & 0,0 & 0,0 & 0,0 & 0,0 & 0,0 & 0,0 & 0,0 & 0,0 \\
\hline & 4 & 9,7 & 0,8 & 5,6 & 3,9 & 22,2 & 2,8 & 7,37 & 0,5 & 11,8 & 0,9 \\
\hline & 8 & 9,2 & 0,2 & 3,9 & 1,2 & 21,9 & 1,6 & 12,8 & 0,9 & 27,0 & 1,7 \\
\hline & 12 & 18,0 & 2,8 & 3,7 & 0,7 & 22,6 & 1,1 & 21,8 & 0,2 & 49,9 & 3,7 \\
\hline & 16 & 16,2 & 1,1 & 6,6 & 1,0 & 32,3 & 8,3 & 35,0 & 3,2 & 89,1 & 5,0 \\
\hline & 20 & 9,7 & 0,6 & 7,9 & 0,5 & 25,5 & 4,2 & 43,8 & 5,1 & 115,8 & 7,8 \\
\hline \multirow{6}{*}{ FP } & 0 & 0,0 & 0,0 & 0,0 & 0,0 & 0,0 & 0,0 & 0,0 & 0,0 & 0,0 & 0,0 \\
\hline & 4 & 11,0 & 0,9 & 1,6 & 1,1 & 20,2 & 2,3 & 8,8 & 0,5 & 9,5 & 1,3 \\
\hline & 8 & 31,7 & 1,0 & 1,7 & 0,1 & 19,4 & 1,1 & 13,5 & 0,2 & 17,2 & 1,8 \\
\hline & 12 & 63,8 & 8,7 & 3,7 & 0,7 & 19,2 & 0,7 & 16,0 & 0,6 & 22,6 & 1,8 \\
\hline & 16 & 47,2 & 4,0 & 5,9 & 0,7 & 22,6 & 5,3 & 22,2 & 1,3 & 33,8 & 2,0 \\
\hline & 20 & 40,3 & 1,8 & 6,4 & 0,5 & 20,5 & 2,8 & 23,7 & 1,1 & 38,1 & 1,5 \\
\hline
\end{tabular}

\subsubsection{Aldeídos}

A concentração de aldeídos, nos três tratamentos, variou de forma crescente com a fase exponencial de crescimento, após a qual ocorreu diminuição da concentração, observando-se picos de concentração após o ponto de máxima produtividade de etanol, retratados nas Figuras 5, 6 e 7 . 


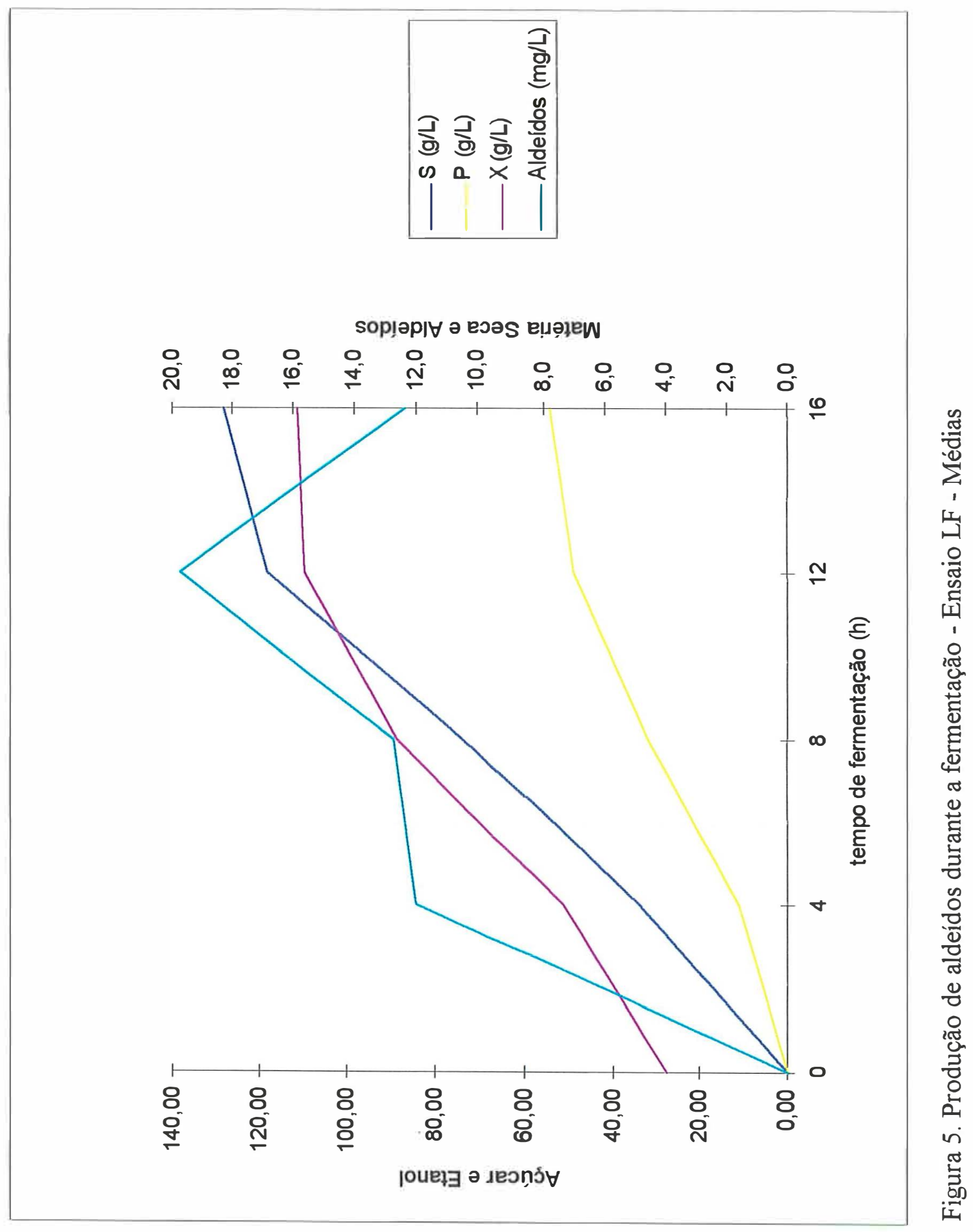




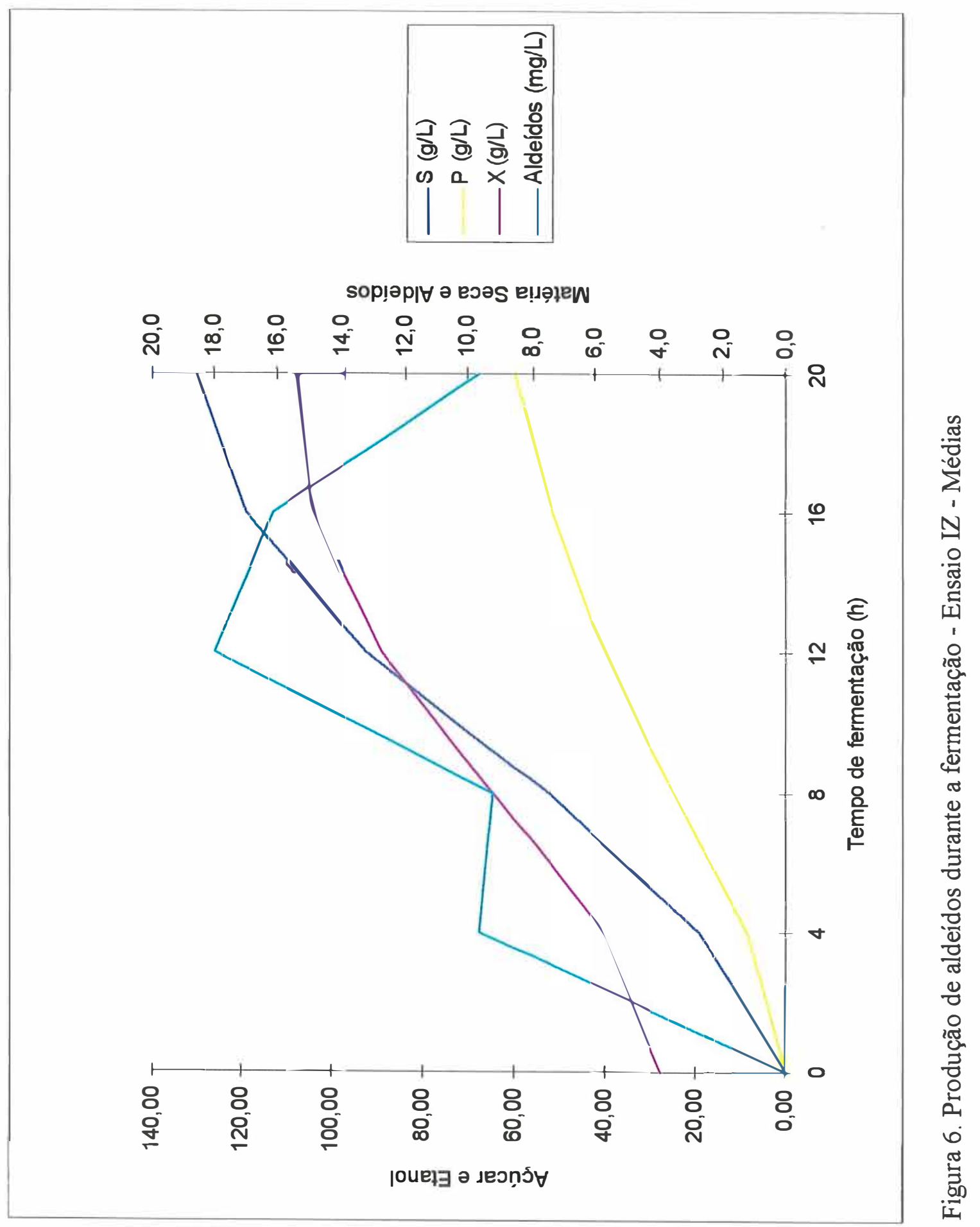




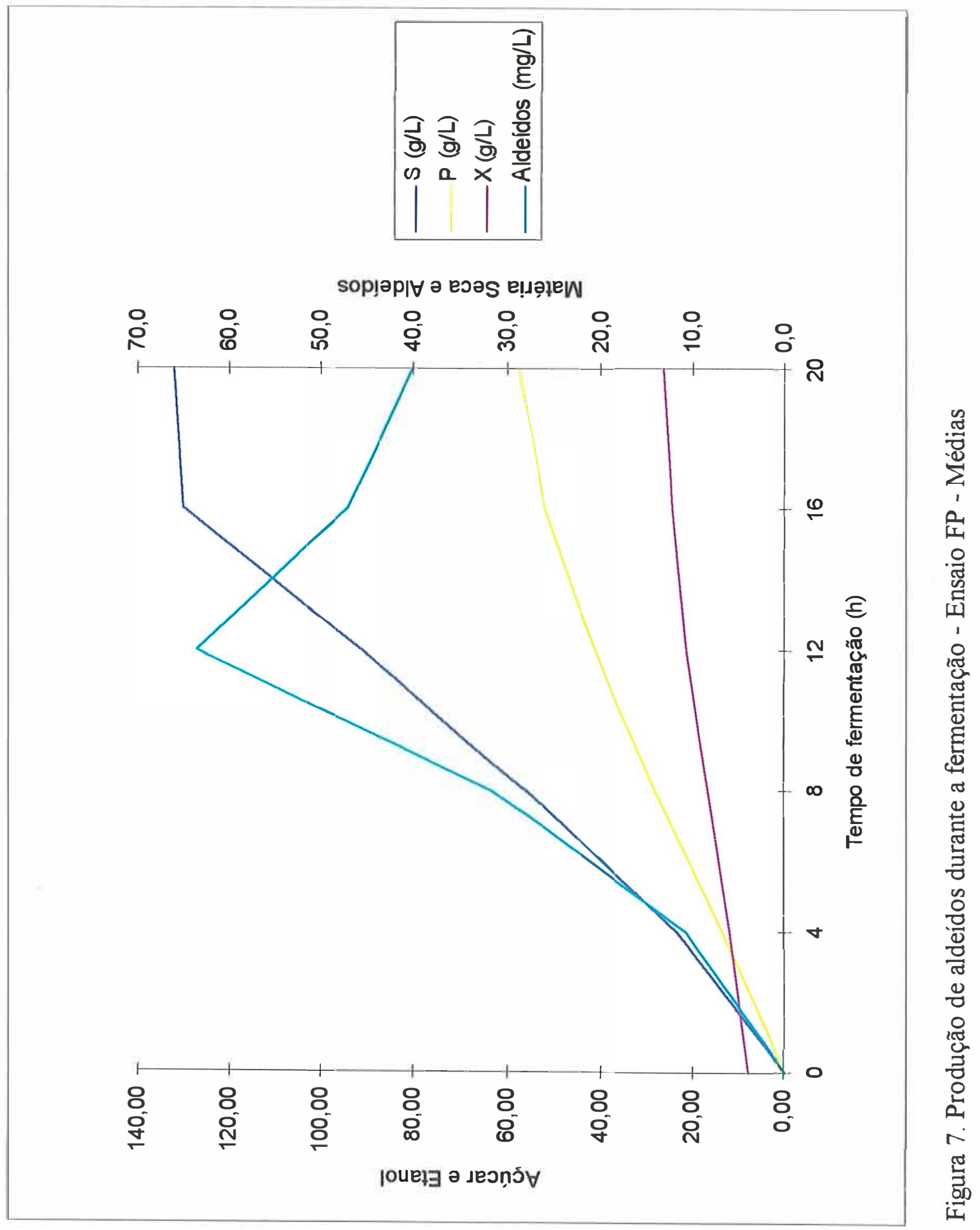


Cachot e colaboradores (1991), em fermentação de mosto de melaço, encontraram dois picos de produção de aldeídos, sendo que o segundo, e maior deles, coincidia com o ponto de maior produtividade de etanol. Para justificar a ocorrência de tais picos, apresentaram hipóteses como a do consumo diferencial de carboidratos.

Rank e colaboradores (1995), em seu trabalho de monitoramento de metabólitos durante fermentação, observaram concentrações crescentes de acetaldeído e a concentração máxima também coincidia com o pico de produtividade de etanol, mesmo nas condições de produção de biomassa, onde é promovida aeração e o fornecimento de carboidratos é mínimo.

No experimento de Groboillot e colaboradores (1989) sobre o monitoramento da formação de compostos voláteis em fermentação de mosto de melaço de beterraba, sob condições de temperatura e de fornecimento de carboidratos muito semelhantes as do presente experimento, foi verificada a mesma tendência de produção de aldeídos, ou seja, crescente até o fim da fase exponencial e decrescente após a mesma.

Os maiores valores de concentração de aldeídos foram obtidos no tratamento FP $\left(63,8 \mathrm{mg} \cdot \mathrm{L}^{-1}\right)$. Nos tratamentos LF e IZ foram observadas concentrações máximas semelhantes (19,8 e 18,0 mg. $\mathrm{L}^{-1}$, respectivamente).

No ensaio de Groboillot e colaboradores (1989) acima citado, as concentrações máximas observadas em suas fermentações não aeradas situaram-se entre 59 e 270 mg. $\mathrm{L}^{-1}$. 


\subsubsection{2. Ésteres}

No tratamento LF a produção de ésteres foi verificada na amostra da $4^{a}$ hora de fermentação. No período seguinte, com amostras de 8 horas, observou-se diminuição da concentração, voltando a crescer na $12^{\underline{a}}$ hora e no final da fermentação, atingindo 5,5 mg. $\mathrm{L}^{-1}$. A maior concentração de ésteres ocorreu na amostra da $12^{\underline{a}}$ hora, no fim da fase exponencial. Tais resultados são ilustrados pela figura 8.

Comportamento semelhante foi verificado no tratamento IZ, onde observou-se concentração de $5,6 \mathrm{mg} \cdot \mathrm{L}^{-1}$ na $4^{\mathrm{a}}$ hora, seguida pela diminuição da concentração na $8^{\mathrm{a}}$ e na $12^{\mathrm{a}}$ hora, voltando a aumentar a concentração na amostra da $20^{\mathrm{a}}$ hora. O maior valor de concentração encontrado foi $7,9 \mathrm{mg} . \mathrm{L}^{-1}$ e a maior produtividade ocorreu na primeira amostra, retirada após 4 horas de fermentação, conforme mostra a figura 9.

No tratamento FP, ocorreu uma tendência crescente de produção de ésteres, embora as concentrações observadas após 4 e 8 horas de fermentação fossem semelhantes. A concentração foi marcadamente maior nas amostras coletadas à $16^{\underline{a}}$ e à $20^{\mathrm{a}}$ hora de fermentação, conforme indica a figura 10. 


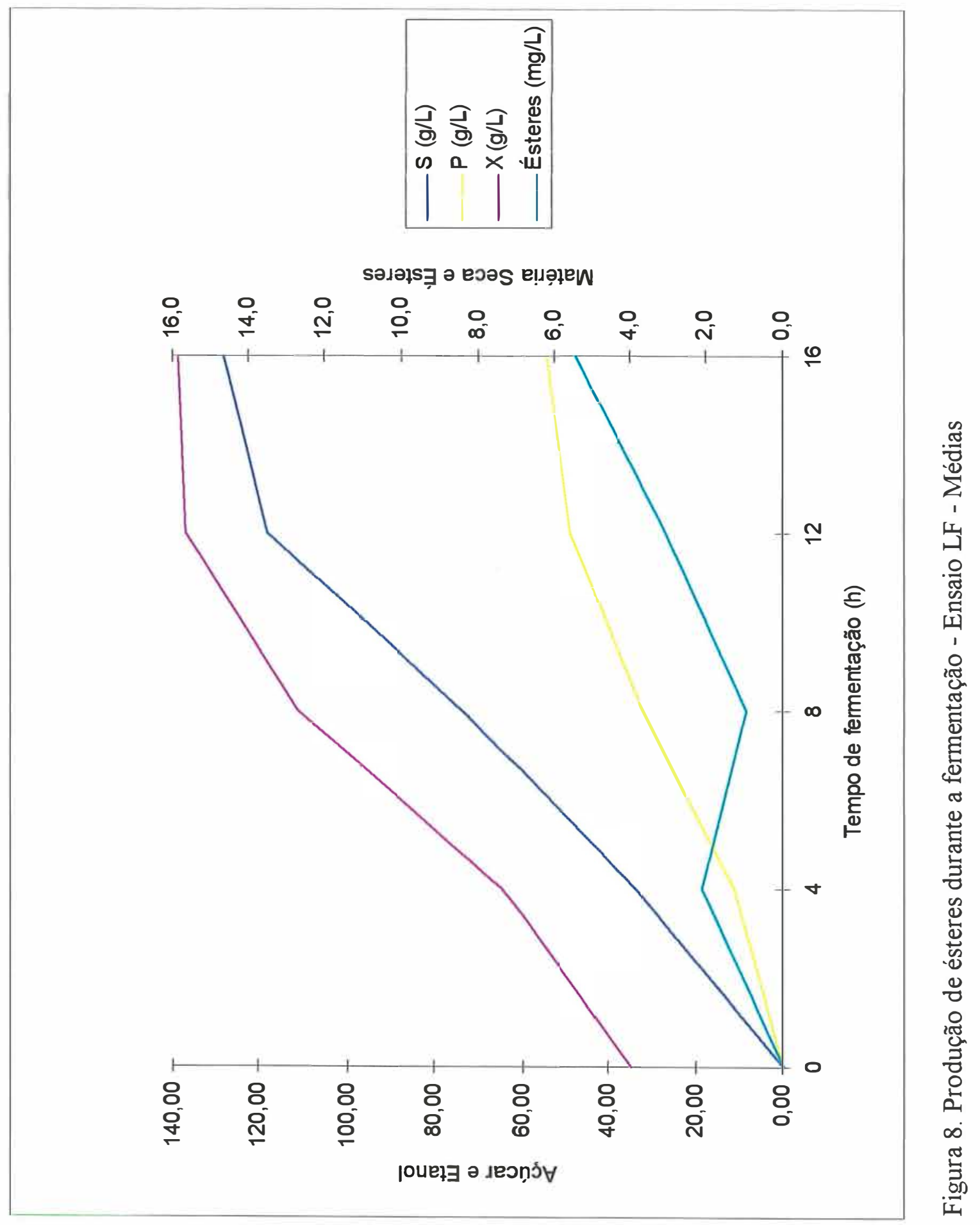




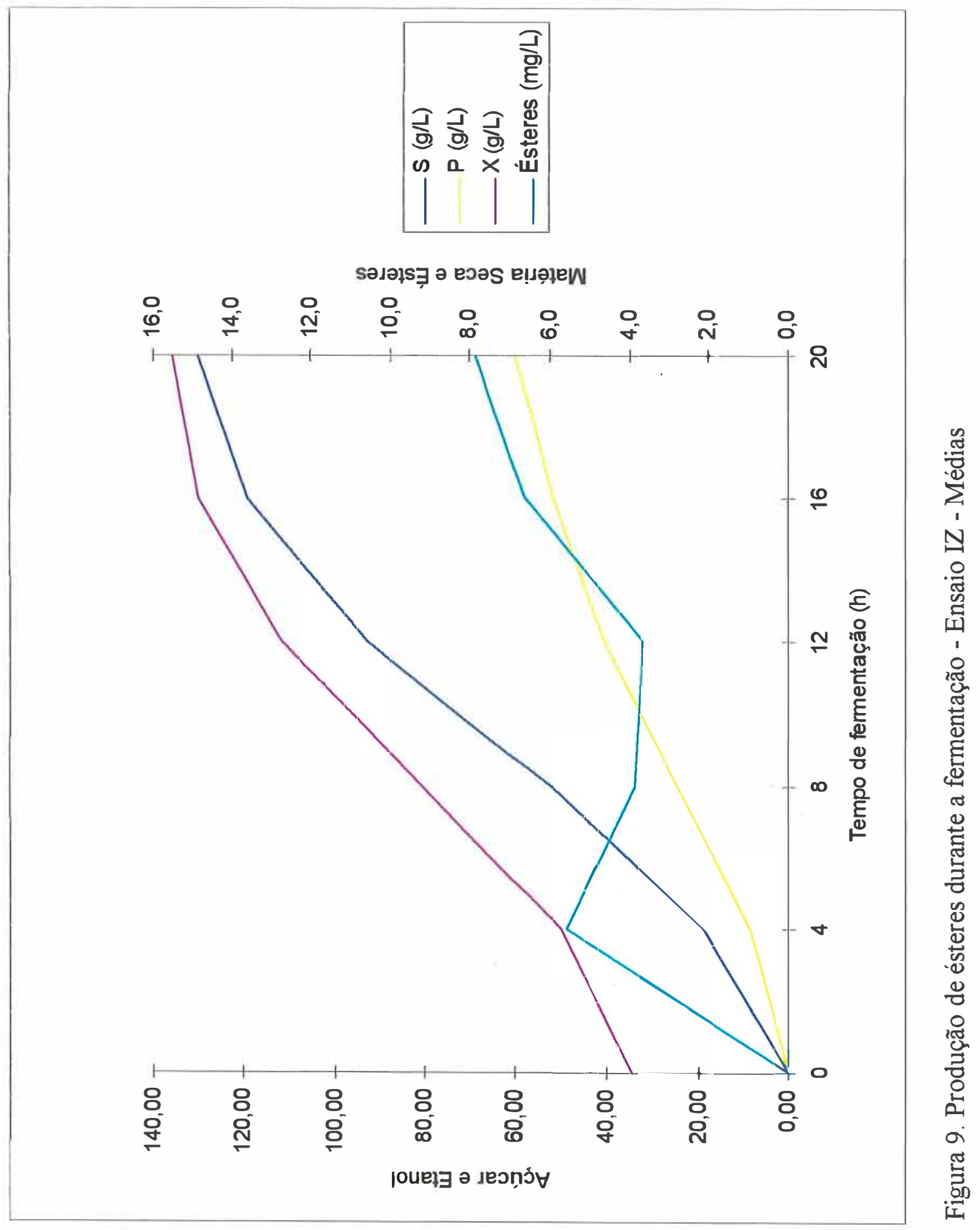




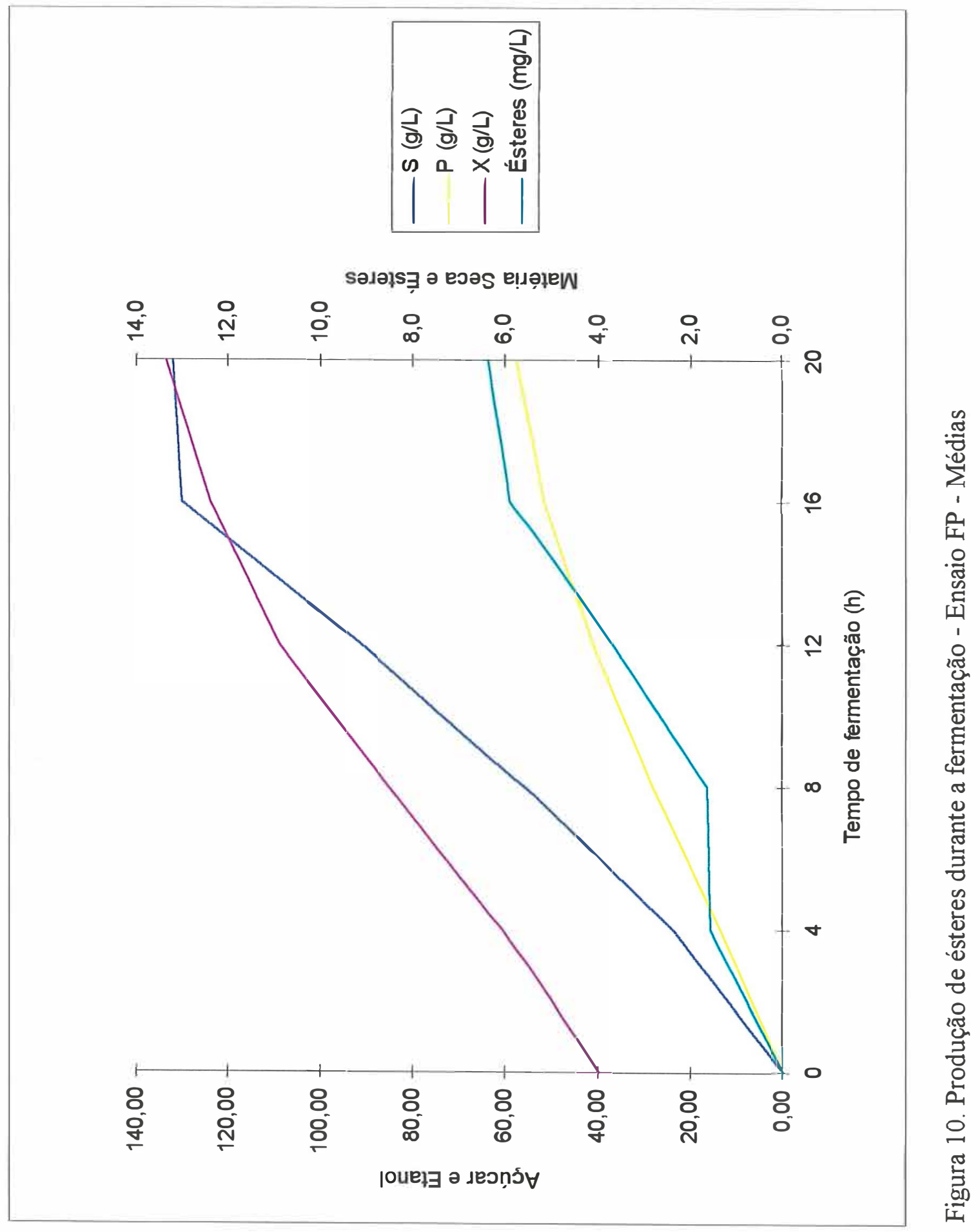


No ensaio de Cachot e colaboradores (1991), as maiores concentrações de ésteres (acetato de etila) foram encontradas após o ponto de máxima produtividade de etanol, já no final da fermentação, o que coincide com os resultados deste experimento.

Groboillot e colaboradores (1989) observaram formação crescente de ésteres durante a fermentação, sendo as maiores concentrações, também observadas no final da fermentações e situando-se entre 4 e $5 \mathrm{mg} \cdot \mathrm{L}^{-1}$, nos experimentos em batelada sem aeração. Essa parece ser a tendência geral das fermentações.

\subsubsection{3. n-Propanol}

A concentração de n-Propanol produzida pela levedura floculante levou ao acúmulo de $17,0 \mathrm{mg} \cdot \mathrm{L}^{-1}$ na amostra após 4 horas de fermentação. Depois deste período, houve uma aparente estabilização até as 12 horas, voltando a ocorrer acúmulo observado pela amostra final às 16 horas. A concentração máxima obtida foi de 27,4 mg. $L^{-1}$ no final da fermentação. Tais dados se encontram na figura 11. 


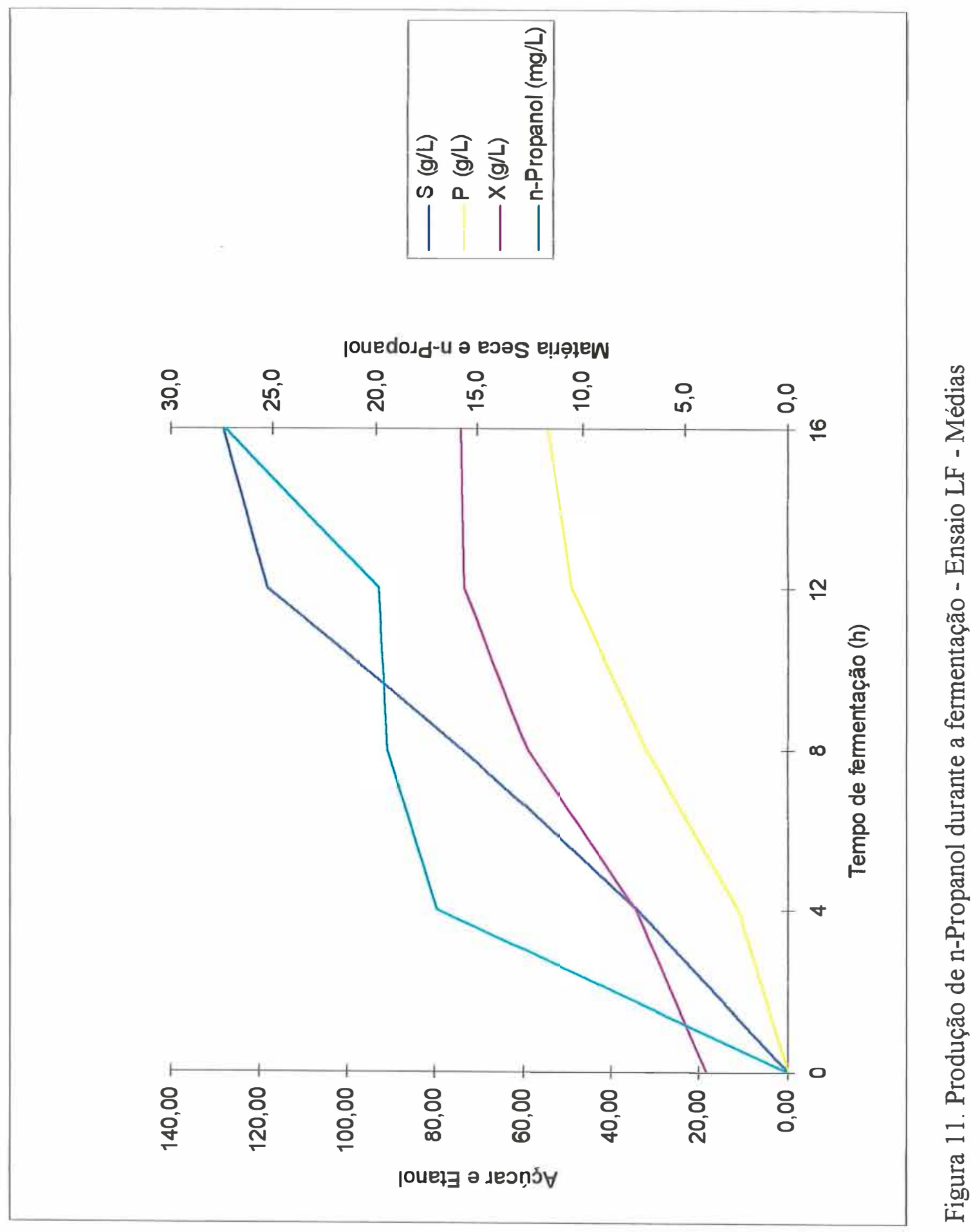




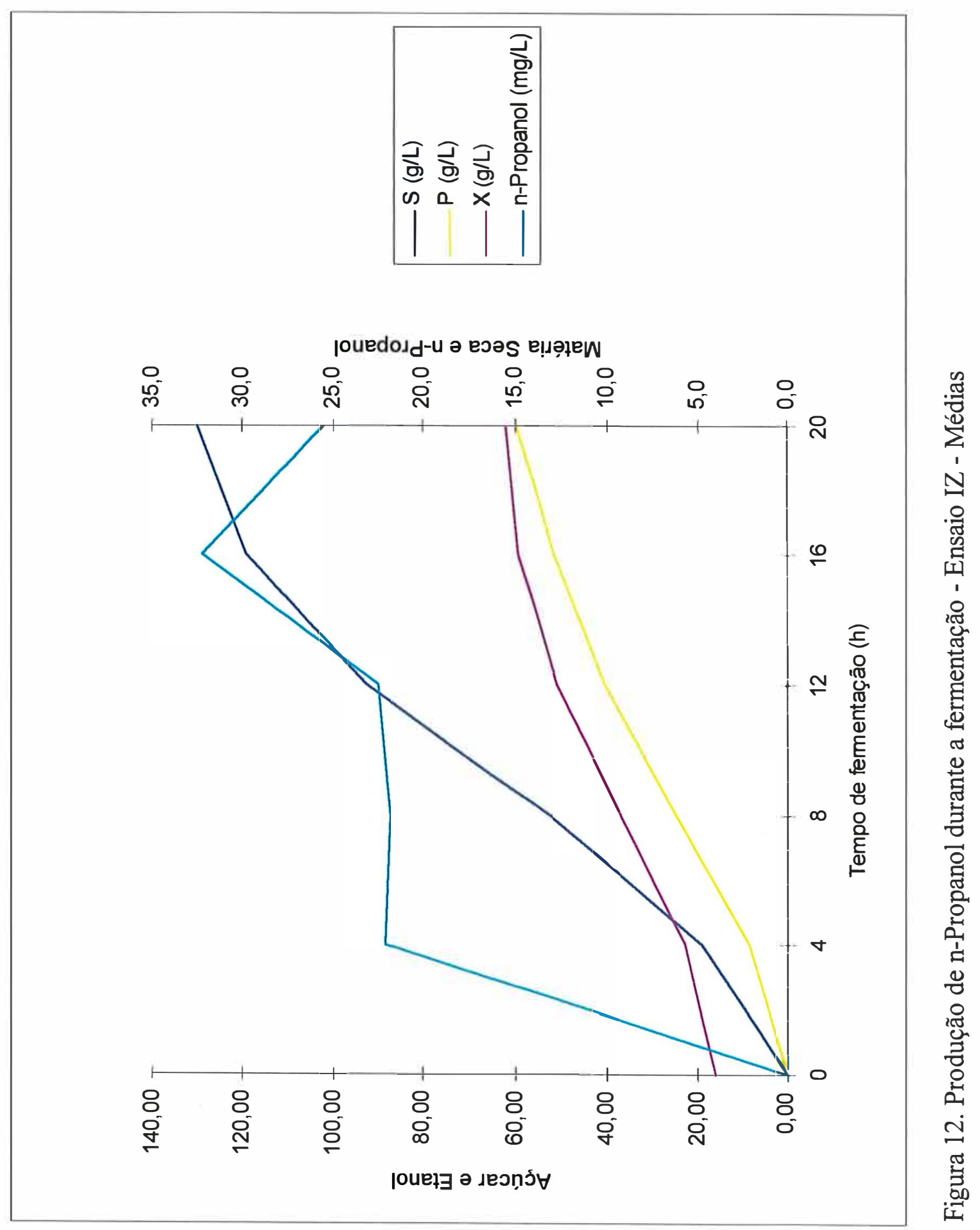




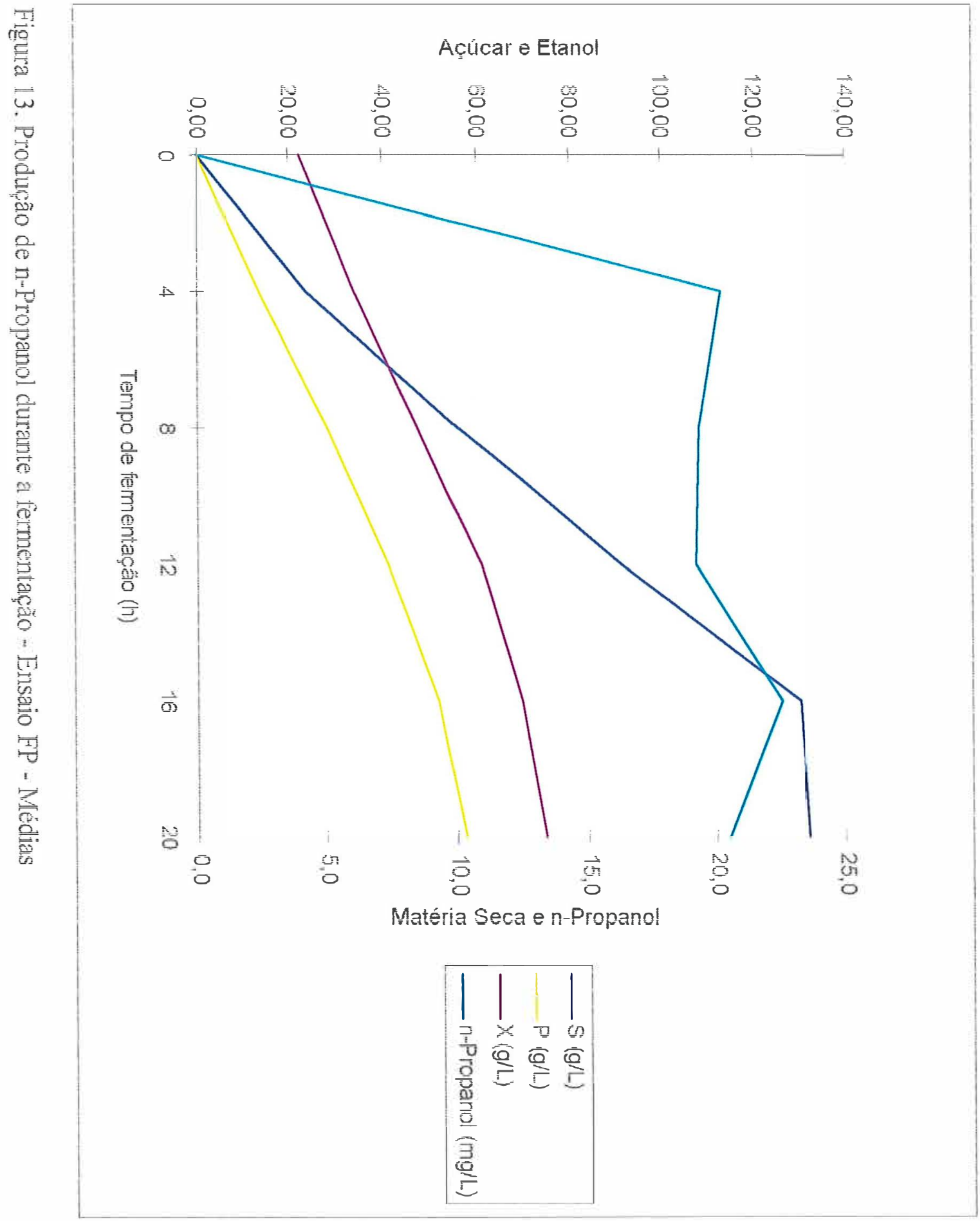


No caso da levedura IZ - 987, conforme mostra a figura 12 ; a produtividade máxima de n-Propanol também ocorreu na amostra da $4^{\underline{a}}$ hora, verificandose estabilização da concentração entre 4 e 12 horas. Nos períodos seguintes observou-se irregularidade de produção. O valor máximo encontrado foi de $32,3 \mathrm{mg} . \mathrm{L}^{-1}$, na amostra correspondente à $16^{\mathrm{a}}$ hora de fermentação.

A mesma tendência ocorreu com a levedura isolada do fermento prensado comercial, onde a fase de maior produtividade ocorreu no período inicial, estabilizando-se os dados entre $4^{\mathrm{a}}$ e $20^{\mathrm{a}}$ horas. A maior concentração observada foi de 22,6 mg. $\mathrm{L}^{-1}$, à 16 ${ }^{\mathrm{a}}$ hora de fermentação. Estes dados estão representados na figura 13.

Giudici e colaboradores (1993), em seu ensaio com diferentes linhagens de leveduras na fermentação de mosto de uvas, verificaram maiores concentrações de nPropanol pelas leveduras não produtoras de gás sulfidrico, o que também foi observado em nosso ensaio.

As maiores concentrações de n-Propanol observadas nas fermentações cujas condições mais se assemelhavam com as de nosso experimento, do ensaio de Groboillot e colaboradores (1989), variaram entre 31 e 46 g.L $\mathrm{L}^{-1}$.

O comportamento dos resultados de recuperação de n-Propanol no preparo das amostras para cromatografia talvez tenha sido influenciado pela técnica de destilação prévia e que esta não era adequada para total recuperação, em função da solubilidade do n-Propanol em etanol e em água, conforme pode se observar no trabalho de Boza (1996). 


\subsubsection{4. i-Butanol}

A produção de i-Butanol se deu com a mesma tendência para as três leveduras estudadas, caminhando quase que paralelamente ao crescimento celular, à produção de etanol e ao consumo de açúcar mostrando claramente a produção de um metabólito primário pouco reativo. Esta tendência foi também verificada no ensaio de Groboillot e colaboradores (1989), sendo observadas concentrações máximas na ordem de 61 a 86 mg. $\mathrm{L}^{-1}$, em vinhos de melaço de beterraba.

A concentração máxima observada no tratamento $\mathrm{LF}$ foi de $28,2 \mathrm{mg} . \mathrm{L}^{-1}$, no fim da fermentação, e seus dados estão representados na figura 14.

A levedura IZ - 987 foi a que mais produziu i-Butanol, encerrando a fermentação com o valor de 43,83mg. $\mathrm{L}^{-1}$, valor máximo observado, conforme figura 15 .

No tratamento FP, a concentração máxima observada foi de 23,7 mg. $\mathrm{L}^{-1}$, também no final da fermentação. Os resultados desta fermentação estão descritos na figura 16. 


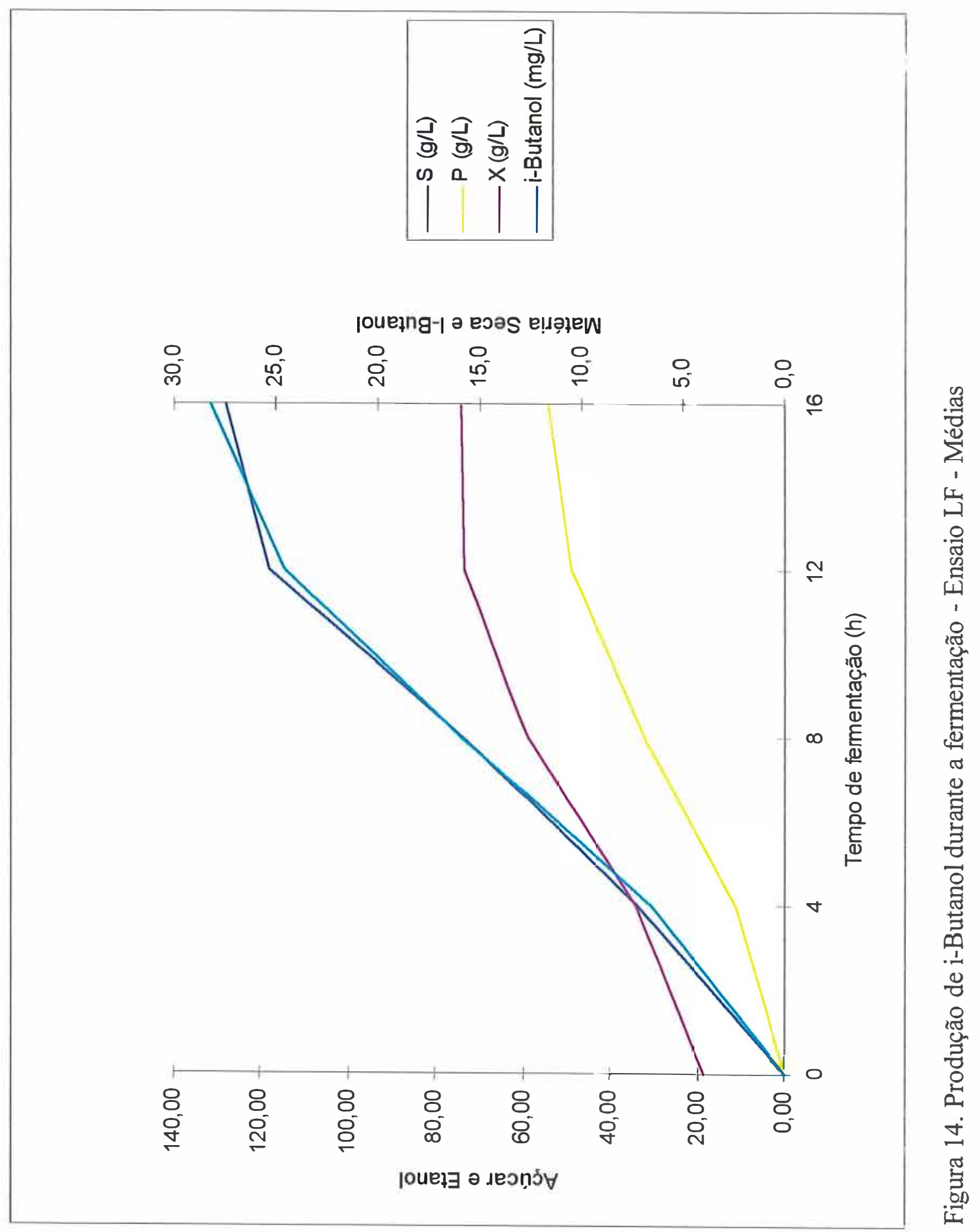




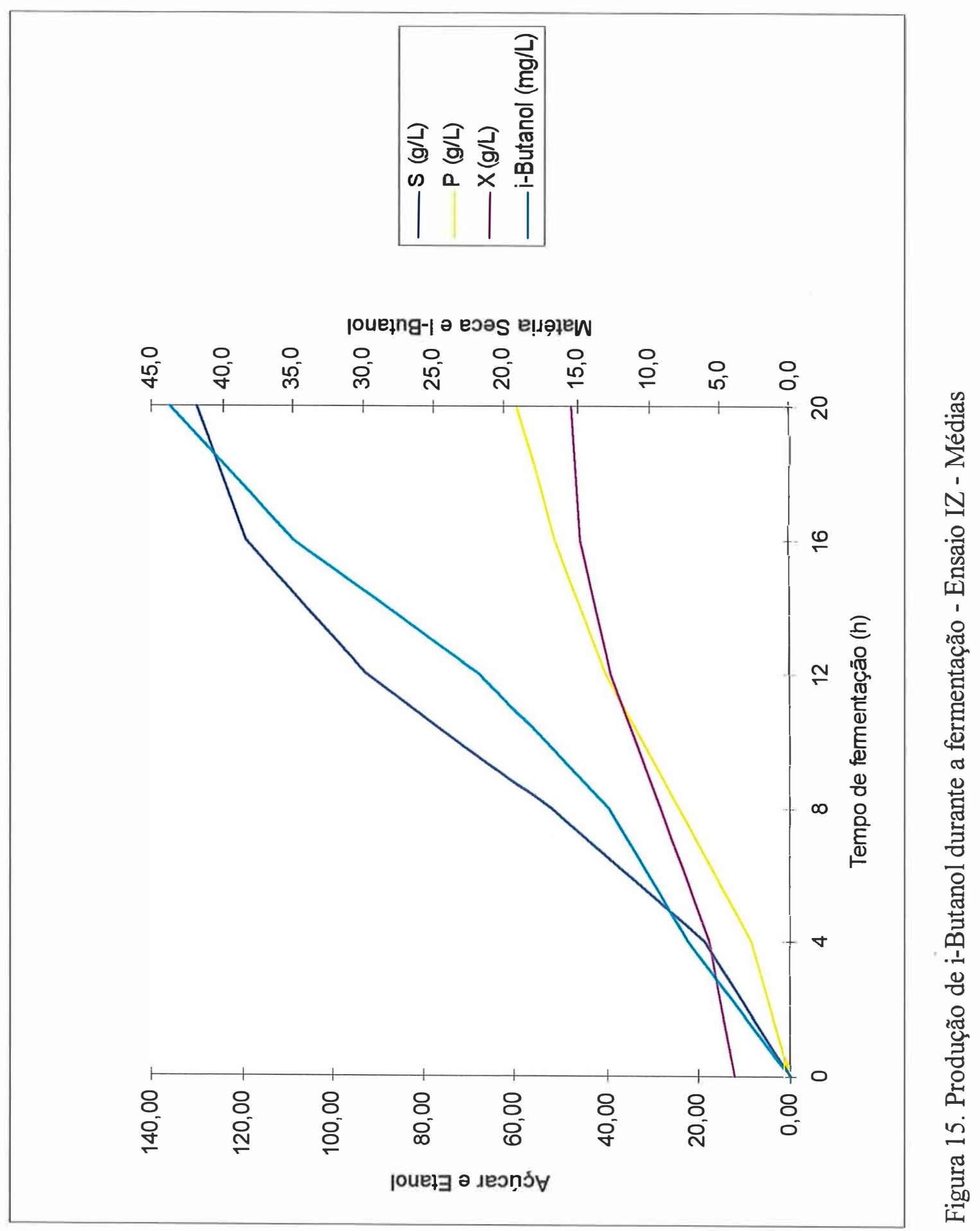




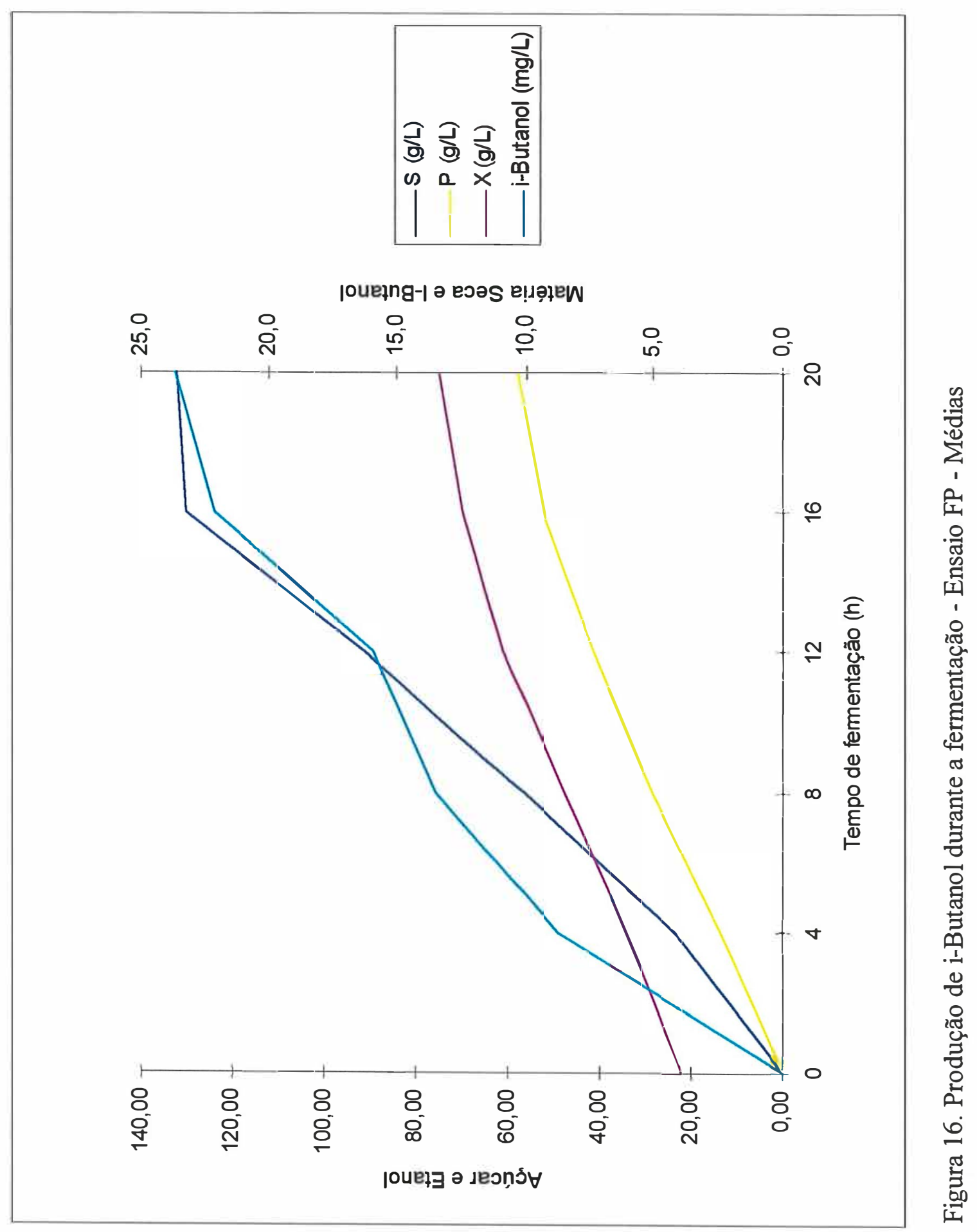




\subsubsection{5. Álcool i-Amílico}

Trata-se de outro metabólito primário que acompanha o crescimento celular e portanto a produção de etanol, o que se verificou nos três tratamentos.

O tratamento LF apresentou maior produtividade de álcool i-Amílico no período compreendido entre 4 e 12 horas de fermentação, chegando ao término desta com a concentração máxima de $62,7 \mathrm{mg} \cdot \mathrm{L}^{-1}$, como indica a figura 17.

A maior produção de álcool i-Amilico foi observada no tratamento IZ, o qual chegou ao final da fermentação com $115,8 \mathrm{mg} \cdot \mathrm{L}^{-1}$. Os resultados estão representados na figura 18.

No trabalho de Giudici e colaboradores (1993), não foi observada produção de outros álcoois superiores, além do n-Propanol, dependente da característica de não produção de $\mathrm{H}_{2} \mathrm{~S}$ das linhagens de levedura utilizadas. Em nosso experimento, a levedura $\mathrm{H}_{2} \mathrm{~S}$ negativa (tratamento IZ) foi a que proporcionou maiores concentrações dos álcoois superiores determinados.

No tratamento FP, a produtividade máxima foi obtida entre 12 e 16 horas de fermentação, sendo que a concentração máxima obtida foi de $38,1 \mathrm{mg} . \mathrm{L}^{-1}$, conforme ilustra a figura 19. 


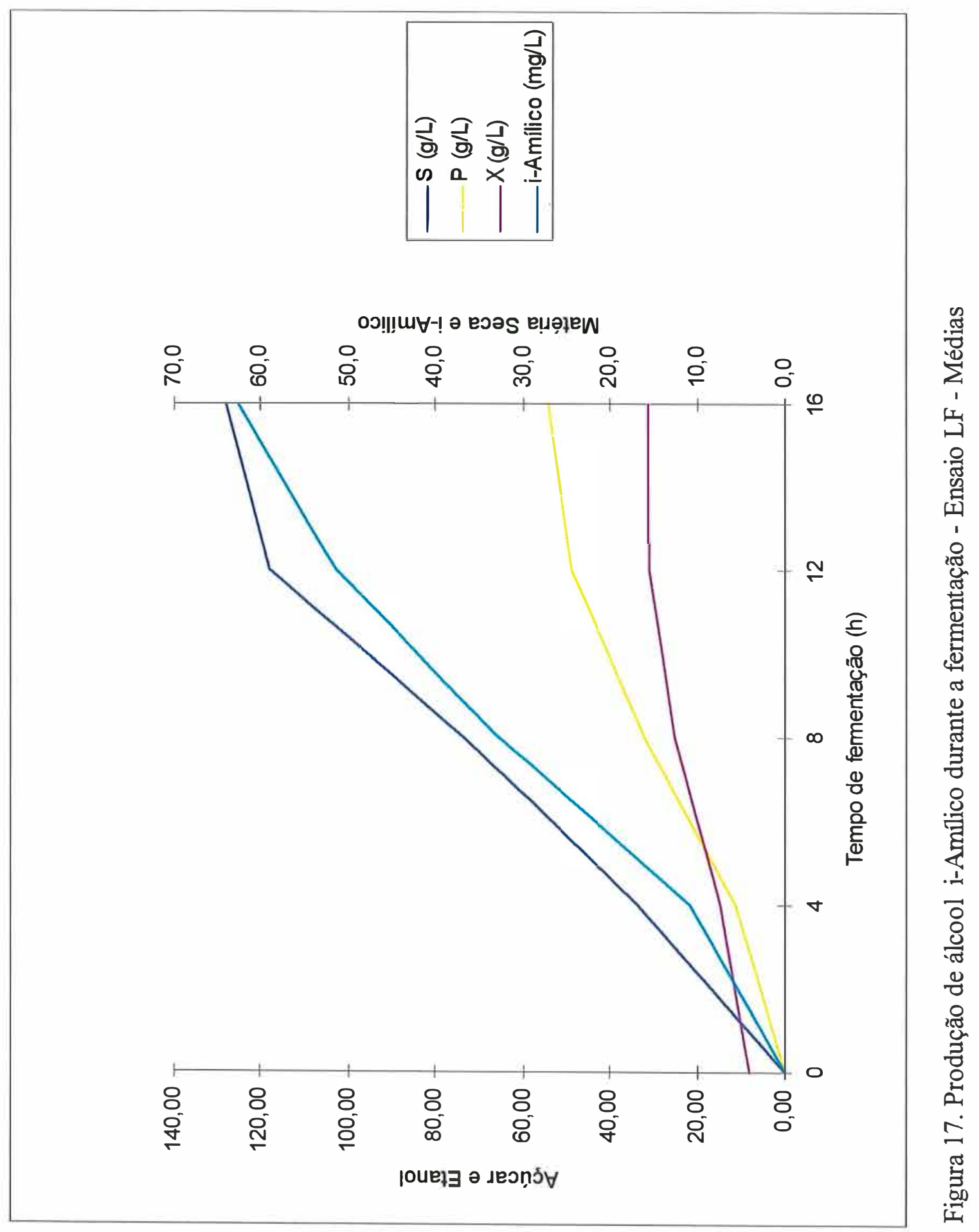




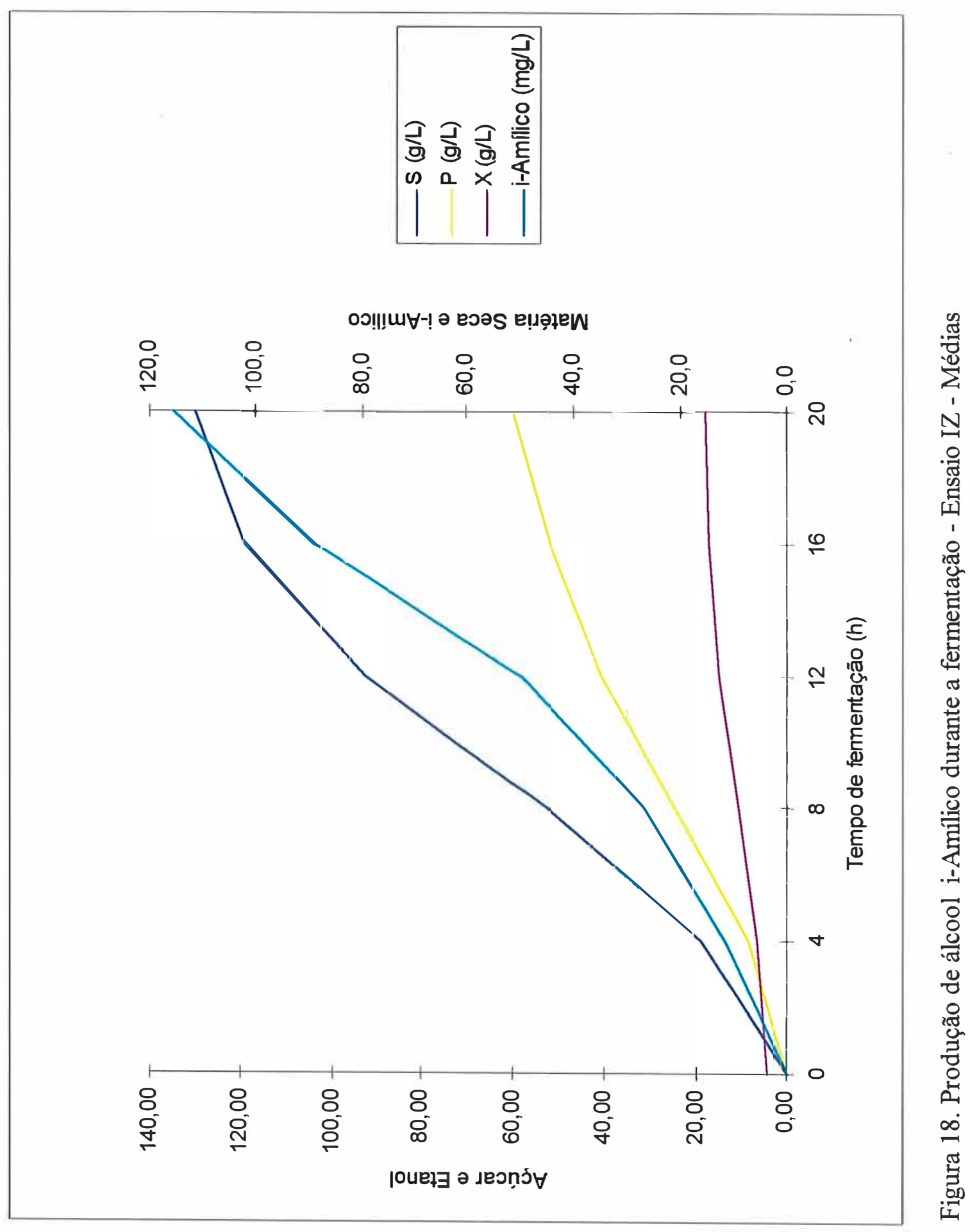




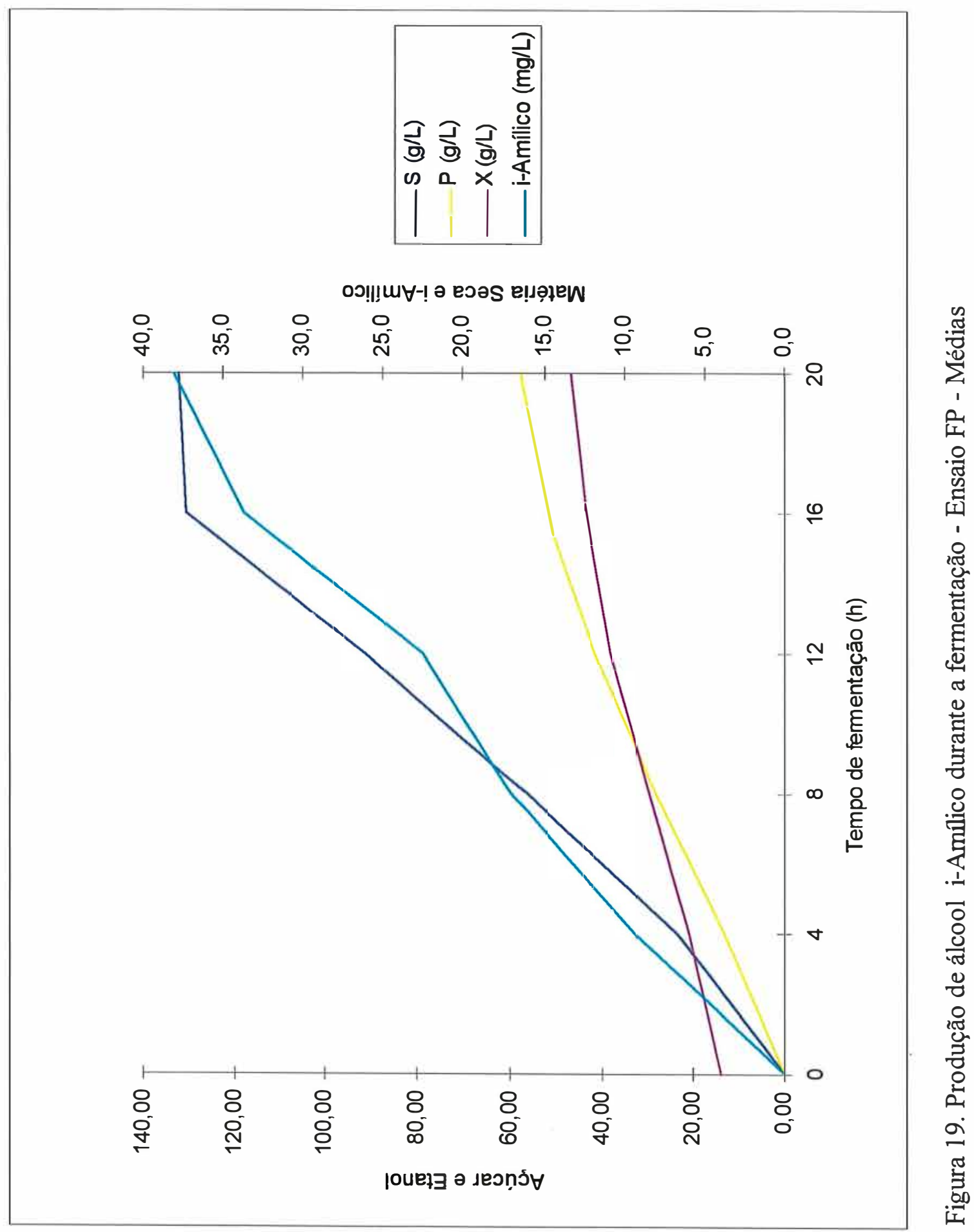


Esta tendência de formação de álcool i-Amilico também foi observada por Nóbrega (1994), no tratamento de fermentação induzida, obtendo vinho com concentração de $210,53 \mathrm{mg} \cdot \mathrm{L}^{-1}$, superior ao maior valor por nós encontrado.

Os resultados das determinações cromatográficas efetuadas sobre as fermentações também se encontram no apêndice 2.

\subsection{Destilação}

\subsubsection{Características dos vinhos}

As características dos vinhos que foram destilados, produzidos pelas respectivas linhagens de levedura, estão ilustradas na tabela 4.

Tabela 4. Resultados das análises dos vinhos destinados à destilação

\begin{tabular}{lccccccc}
\hline Tratamento & \multicolumn{3}{c}{ LF } & \multicolumn{3}{c}{$\mathrm{IZ}$} & \multicolumn{3}{c}{ FP } \\
\cline { 2 - 8 } & média & $\mathrm{s}$ & média & $\mathrm{s}$ & média & $\mathrm{s}$ \\
\hline Volume (L) & 14 & 0,00 & 14 & 0,00 & 14 & 0,00 \\
Etanol (\% v.v $\left.{ }^{-1}\right)$ & 6,91 & 0,04 & 7,59 & 0,13 & 7,30 & 0,04 \\
Acidez (mg. $\left.\mathrm{L}^{-1}\right)$ & 379 & 3,40 & 458 & 31,12 & 504 & 5,89 \\
Leveduras suspensas $\left(\mathrm{g} . \mathrm{L}^{-1}\right)$ & 0,18 & 0,03 & 0,22 & 0,02 & 3,27 & 0,17 \\
\hline
\end{tabular}

A principal diferença entre os tratamentos ilustrada nesta tabela é a concentração de leveduras suspensas que, para as leveduras floculantes (tratamentos LF e 
IZ) são bem inferiores, em função da maior velocidade de decantação promovida pelo tamanho das partículas, ou seja, dos flocos formados.

\subsubsection{Análises dos destilados}

As determinações de temperatura final de destilação das frações de 200 $\mathrm{mL}$, do tempo para o recolhimento de cada fração e de seus respectivos valores de massa específica, concentração de etanol e de acidez, efetuadas na destilação dos vinhos fermentados nos três ensaios estão ilustradas no apêndice 3.

O critério seguido na operação de destilação permitiu, no ensaio LF, a produção de 9 frações de 200mL, com teores alcoólicos variande de 75,48\% a 21,02\%. Os valores de acidez de cada amostra variaram de 6,16 a 9,52 $\mathrm{mg}$ de ácido acético. $100 \mathrm{~mL}^{-1}$, com a curva representada na figura 20 .

No tratamento IZ obteve-se 11 frações de $200 \mathrm{~mL}$, podendo-se associar este maior volume de destilado, em parte, ao maior teor alcoólico do vinho deste tratamento. Os valores de teor alcóolico das frações variaram de 74,88 a 11,97\% e os de acidez situaram-se entre 5,60 e 7,12 mg de ácido acético. $100 \mathrm{~mL}^{-1}$, conforme o observado na figura 21.

O tratamento FP possibilitou a retirada de 10 frações de $200 \mathrm{~mL}$, com valores de graduação alcoólica variando de 75,91 a $19,08 \%$. Neste tratamento foram observados maiores valores de acidez variando de 12,3 a $17,5 \mathrm{mg}$ de ácido acético. $\mathrm{L}^{-1}$. 
Porém, nota-se que a respectiva curva, representada pela figura 22 , mostra tendência de arraste de acidez pela destilação semelhante aos demais tratamentos.

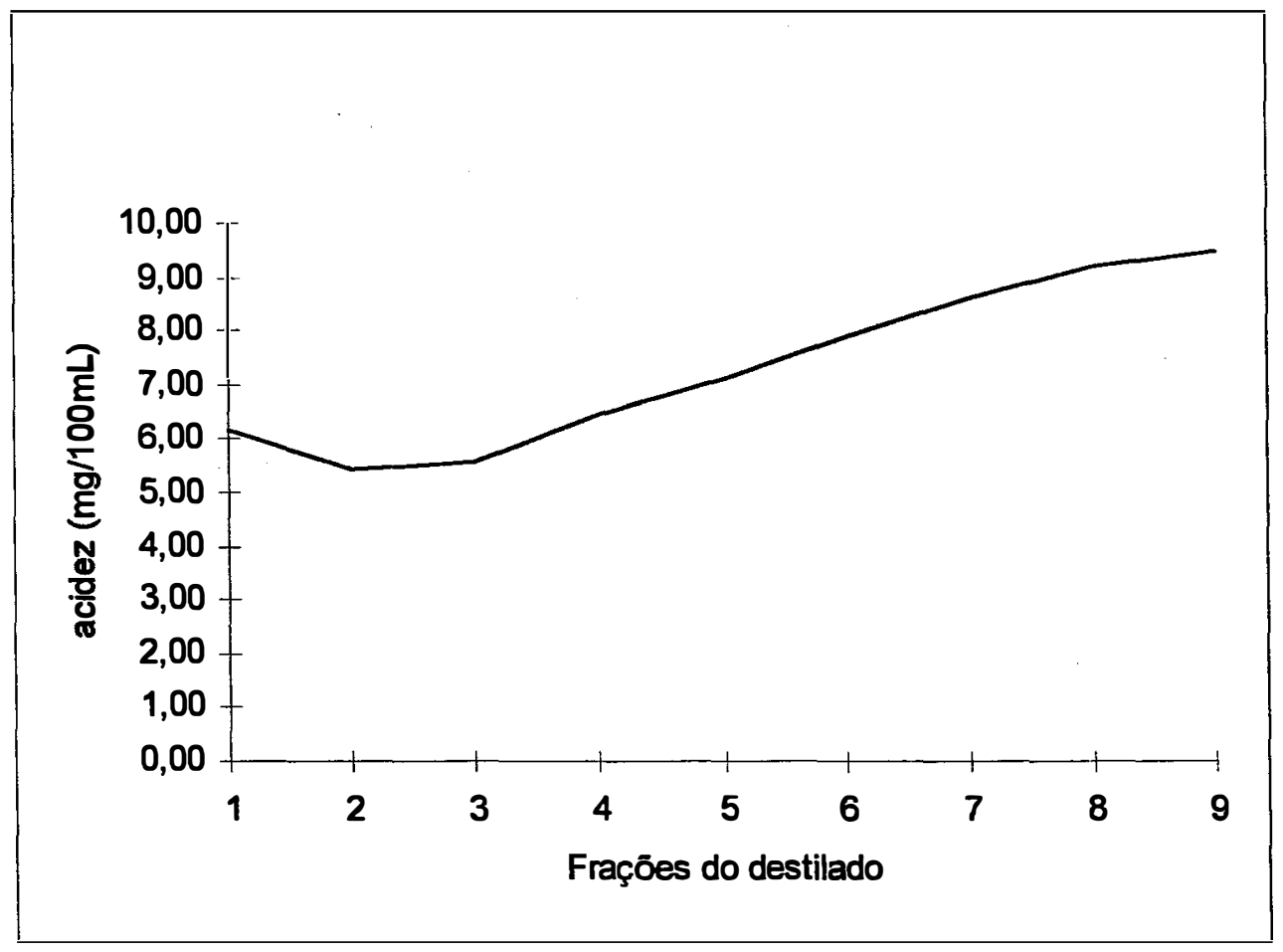

Figura 20 - Acidez das frações destiladas - Ensaio LF - Médias 


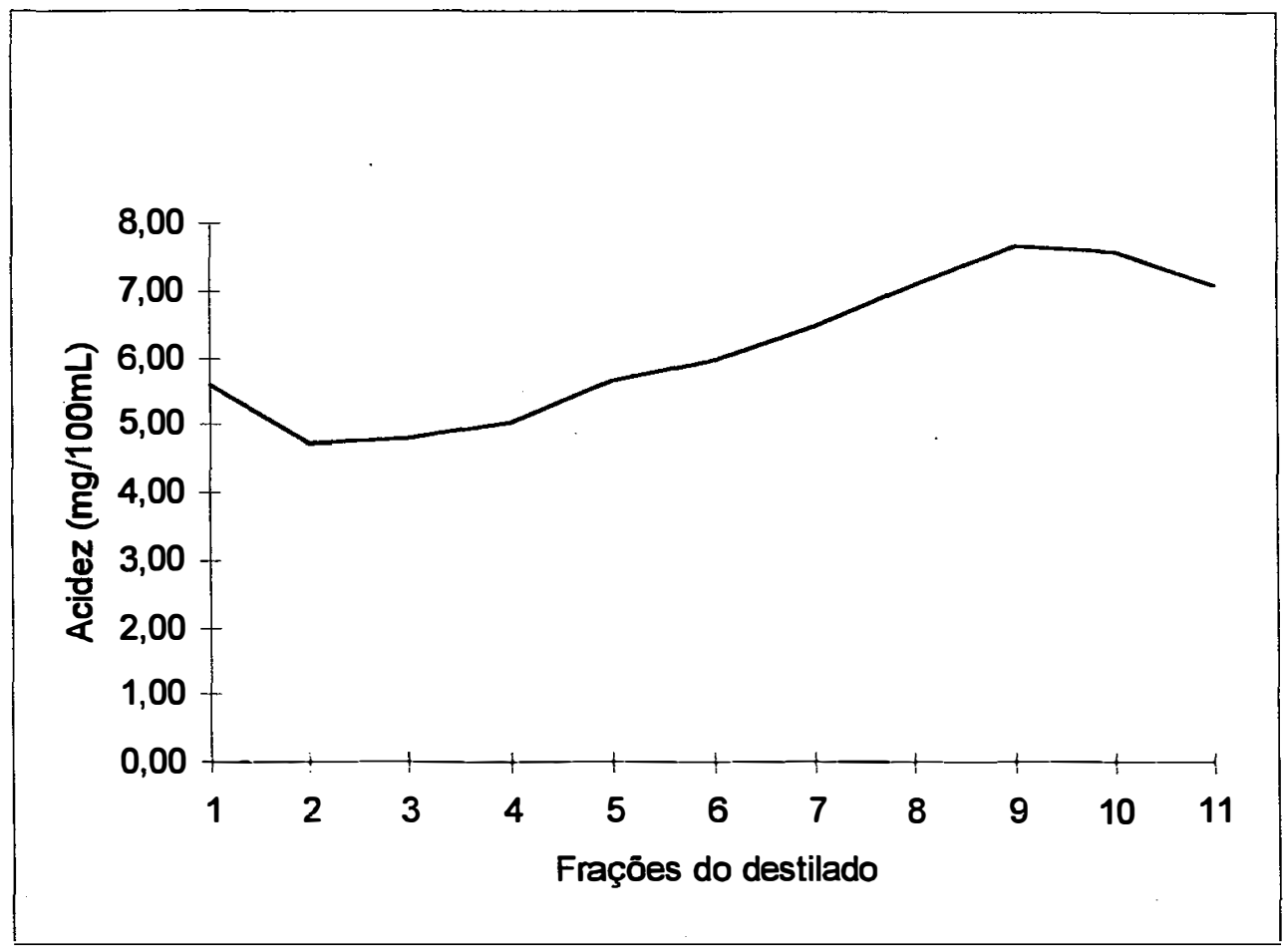

Figura 21 - Acidez das frações destiladas - Ensaio IZ - Médias

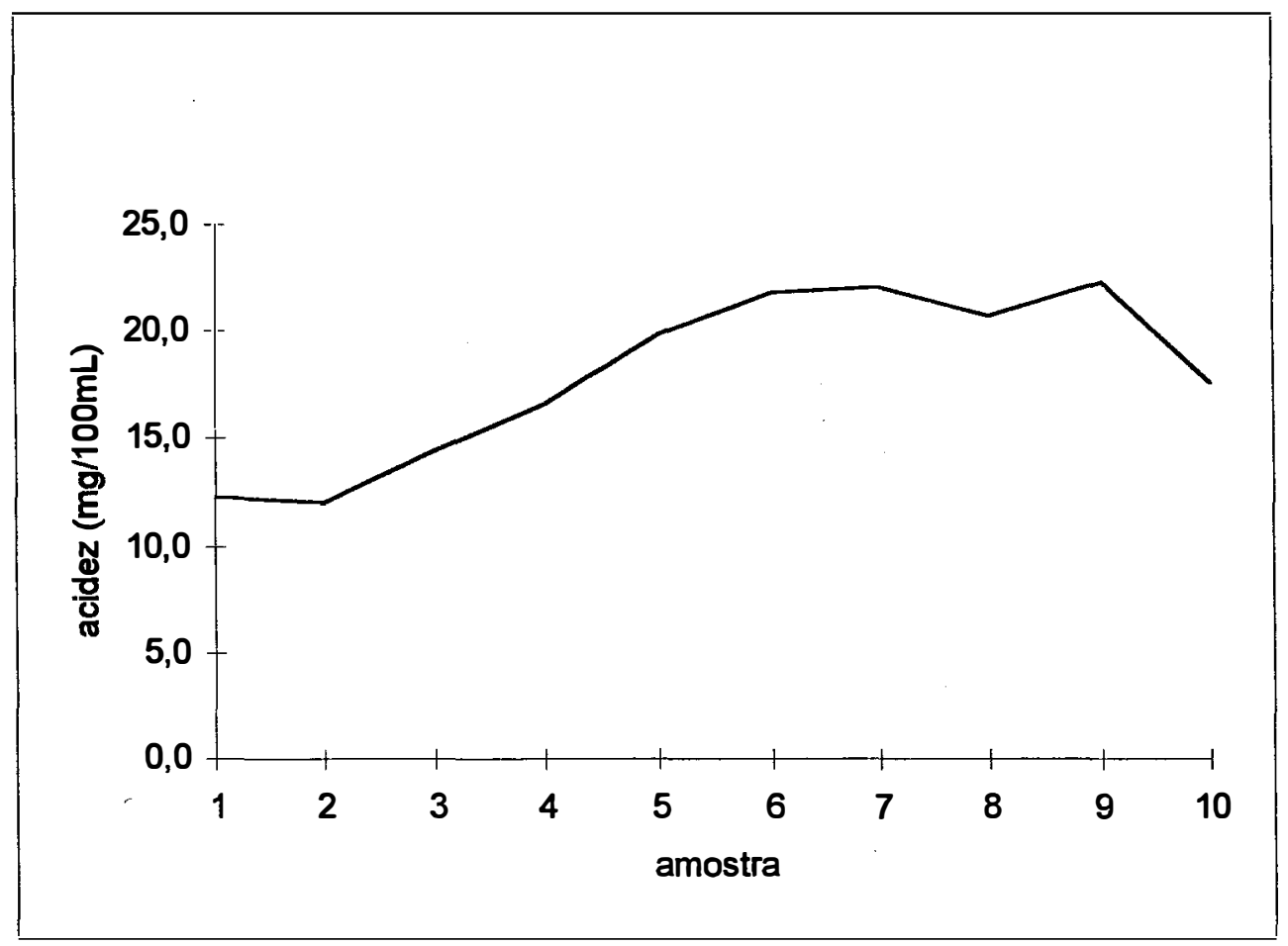

Figura 22 - Acidez das frações destiladas - Ensaio FP - Médias 
Tais perfis de acidez durante a destilação foram também observados no experimento de Lafon et al. ${ }^{1}$, citados por Amerine e colaboradores (1972), em estudos de produção de "brandy" e, mais recentemente por Boza (1996), na produção de aguardente de cana.

\subsection{Padronização e análises das aguardentes}

Em função da curva de acidez obtida nas frações destiladas, definiu-se que as aguardentes seriam compostas pelas frações 1 a 5 .

A partir desta mistura, diluiu-se os destilados à graduação alcoólica de $40 \%\left(\mathrm{v} \cdot \mathrm{v}^{-1}\right)$, sobre os quais estão expressos na tabela 5 os resultados das determinações efetuadas.

Foi observado que as aguardentes, produzidas sob as condições préestabelecidas neste experimento, que excederam os limites de qualidade estabelecidos pelo Decreto $\mathrm{n}^{\mathbf{0}} 73.267$ de setembro de 1974 (Brasil, 1974), foram a do ensaio FP, que superou o limite de Cobre (5ppm), produzindo 11,1 ppm e, menos intensamente, o limite de aldeídos (30 mg de aldeído acético. $100 \mathrm{~mL}^{-1}$ de etanol a 100\%), que mostrou valor de $30,26 \mathrm{mg}$ de aldeído acético. $100 \mathrm{~mL}^{-1}$ de etanol a $100 \%$, e a do ensaio IZ, que excedeu o limite de álcoois superiores produzindo $376,08 \mathrm{mg} \cdot 100 \mathrm{~mL}^{-1}$ de etanol a $100 \%$.

\footnotetext{
${ }^{1}$ LAFON, R.; LAFON, J.; COUILLAUD, P. Le cognac; sa distillation. Paris: J.B. Baillière et Fils, 1964. apud AMERINE, M.A.; BERG, H.W.; CRUESS, W.V. The technology of wine making. Westport, AVI Publishing Company. $3^{\text {rd }}$ ed. , 1972, 802p.
} 
O ensaio FP produziu 15,83 e 11,69 mg ác.acético $.100 \mathrm{~mL}^{-1}$ de etanol a $100 \%$ de acidez total e volátil, respectivamente, valores que são bem superiores aos produzidos pelos outros ensaios. Estes valores de acidez são fiéis aos valores de acidez encontrados nos vinhos deste mesmo ensaio, onde a linhagem FP foi a maior produtora de acidez.

Tabela 5 - Análises das aguardentes obtidas dos tratamentos

\begin{tabular}{|c|c|c|c|}
\hline & LF & IZ & FP \\
\hline Densidade aparente $\left(20 / 4^{\circ} \mathrm{C}\right)$ & 0,9481 & 0,9480 & 0,9480 \\
\hline Grau alcoólico aparente $\%\left(\mathrm{v} \cdot \mathrm{v}^{-1}\right)$ & 39,97 & 40,03 & 40,03 \\
\hline Densidade real $\left(20 / 4^{\circ} \mathrm{C}\right)$ & 0,9480 & 0,9482 & 0,9480 \\
\hline Grau alcoólico real \%(v.v $\left.{ }^{-1}\right)$ & 40,03 & 39,91 & 40,03 \\
\hline Acidez total (mgCH $\left.{ }_{3} \mathrm{COOH} .100 \mathrm{~mL}^{-1} \mathrm{ETOH} 100 \%\right)$ & 5,36 & 2,65 & 15,83 \\
\hline Acidez volátil (mgCH $\left.{ }_{3} \mathrm{COOH} .100 \mathrm{~mL}^{-1} \mathrm{ETOH} 100 \%\right)$ & 5,40 & 2,21 & 11,69 \\
\hline Acidez fixa $\left(\mathrm{mgCH}_{3} \mathrm{COOH} .100 \mathrm{~mL}^{-1} \mathrm{ETOH} 100 \%\right)$ & 0,00 & 0,44 & 4,14 \\
\hline Cobre (ppm) & 0,0 & 0,0 & 11,1 \\
\hline Extrato seco (g.L $\left.{ }^{-1}\right)$ & 0,06 & 0,12 & 0,22 \\
\hline Aldeídos (mg aldeído acético. $100 \mathrm{~mL}^{-1}$ ETOH $100 \%$ ) & 12,81 & 7,16 & 30,26 \\
\hline Acetona (mg. $100 \mathrm{~mL}^{-1}$ ETOH $\left.100 \%\right)$ & 1,86 & 1,08 & 1,49 \\
\hline Ésteres (mg.100mL $\mathrm{mL}^{-1}$ ETOH 100\%) & 91,74 & 126,78 & 95,72 \\
\hline 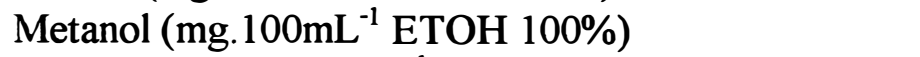 & 4,83 & 4,46 & 4,19 \\
\hline n-Propanol (mg. $100 \mathrm{~mL}^{-1}$ ETOH $\left.100 \%\right)$ & 81,56 & 72,85 & 63,43 \\
\hline i-Butanol (mg. 100mL $\mathrm{m}^{-1}$ ETOH 100\%) & 64,43 & 101,73 & 54,78 \\
\hline N-Butanol (mg. $100 \mathrm{~mL}^{-1}$ ETOH 100\%) & 2,74 & 1,85 & 0,94 \\
\hline i-Amílico (mg. 100mL $\mathrm{m}^{-1}$ ETOH 100\%) & 111,97 & 199,65 & 69,38 \\
\hline N-Amílico (mg.100mL m $^{-1}$ ETOH 100\%) & 0,00 & 0,00 & 0,00 \\
\hline Álcoois superiores (mg. $100 \mathrm{~mL}^{-1}$ ETOH $100 \%$ ) & 260,70 & 376,08 & 188,53 \\
\hline Compostos secundários (mg. $100 \mathrm{~mL}^{-1}$ ETOH $100 \%$ ) & 370,65 & 512,23 & 362,2 \\
\hline
\end{tabular}

A única aguardente que apresentou Cobre foi a do tratamento FP; tal fato pode ser justificado pela maior acidez do destilado que solubiliza o metal constituinte 
do condensador do aparelho de destilação, fato este também já levantado por Boza (1996).

Quanto aos componentes orgânicos determinados por cromatografia, foi observado que na aguardente do tratamento FP existia maior concentração de aldeídos totais que nas aguardentes dos tratamentos LF e IZ, conforme o indicado pela tabela 5.

A destilação do vinho resultante da fermentação de mosto sem nitrogênio estudada por Suomalainen \& Nykänen (1966), mostrou que o produto destilado na presença de leveduras possuia maior concentração de aldeídos que o do vinho delevurado. No presente experimento o vinho que foi destilado do tratamento FP continha quantidade de levedura suspensa muito superior a dos tratamentos LF e FP, conforme ilustrado na tabela 4, que são de leveduras floculantes e, após o término da fermentação, precipitam proporcionando vinhos praticamente límpidos.

Maiores teores de ésteres e de álcoois superiores foram encontrados na aguardente produzida pela levedura IZ - 987. A aguardente do tratamento LF também continha teores de álcoois superiores maiores que a do tratamento FP, mostrando a maior habilidade destas leveduras floculantes na produção destes compostos.

As frações correspondentes à cauda (fração $6 \mathrm{em}$ diante), após misturadas, foram submetidas às análises que constam na tabela 6 . 
Tabela 6 - Análises da mistura de frações dos destilados correspondentes à cauda

\begin{tabular}{|c|c|c|c|}
\hline & LF & IZ - 987 & FP \\
\hline Densidade aparente $\left(20 / 4^{\circ} \mathrm{C}\right)$ & 0,9621 & 0,9660 & 0,9568 \\
\hline Grau alcoólico aparente $\%\left(v \cdot v^{-1}\right)$ & 30,12 & 26,85 & 34,16 \\
\hline Densidade real $\left(20 / 4^{\circ} \mathrm{C}\right)$ & 0,9618 & 0,9655 & 0,9562 \\
\hline Grau alcoólico real \%(v.v $\left.{ }^{-1}\right)$ & 30,36 & 27,28 & 34,59 \\
\hline Acidez total $\left(\mathrm{mgCH}_{3} \mathrm{COOH} .100 \mathrm{~mL}^{-1} \mathrm{ETOH} 100 \%\right)$ & 34,47 & 27,45 & 55,51 \\
\hline Acidez volátil $\left(\mathrm{mgCH}_{3} \mathrm{COOH} \cdot 100 \mathrm{~mL}^{-1} \mathrm{ETOH} 100 \%\right)$ & 32,02 & 25,51 & 40,24 \\
\hline Acidez fixa $\left(\mathrm{mgCH}_{3} \mathrm{COOH} .100 \mathrm{~mL}^{-1} \mathrm{ETOH} 100 \%\right)$ & 2,45 & 1,94 & 28,81 \\
\hline Cobre (ppm) & 9,6 & 7,1 & 26,7 \\
\hline Extrato seco (g.L $\left.{ }^{-1}\right)$ & 0,08 & 0,12 & 0,26 \\
\hline Aldeídos(mg aldeído acético. $100 \mathrm{~mL}^{-1}$ ETOH $100 \%$ ) & 4,19 & 0,00 & 14,44 \\
\hline Acetona (mg. $100 \mathrm{~mL}^{-1}$ ETOH $\left.100 \%\right)$ & 0,00 & 0,00 & 0,57 \\
\hline Ésteres (mg. $100 \mathrm{~mL}^{-1}$ ETOH 100\%) & 2,31 & 2,54 & 8,59 \\
\hline Metanol (mg.100mL ${ }^{-1}$ ETOH 100\%) & 3,32 & 3,32 & 7,04 \\
\hline n-Propanol (mg.100 $\mathrm{mL}^{-1}$ ETOH $\left.100 \%\right)$ & 54,77 & 46,27 & 43,04 \\
\hline i-Butanol (mg.100mL ${ }^{-1}$ ETOH 100\%) & 3,60 & 6,98 & 4,03 \\
\hline n-Butanol (mg.100mL ${ }^{-1}$ ETOH 100\%) & 0,00 & 0,00 & 0,00 \\
\hline i-Amílico (mg.100mL ${ }^{-1}$ ETOH 100\%) & 3,83 & 9,88 & 4,34 \\
\hline n-Amílico (mg.100mL ${ }^{-1}$ ETOH 100\%) & 0,00 & 0,00 & 0,00 \\
\hline Álcoois superiores (mg.100mL $\mathrm{mLTH}^{-1}$ ETOH) & 62,20 & 63,13 & 51,41 \\
\hline Compostos secundários (mg. $100 \mathrm{~mL}^{-1}$ ETOH $100 \%$ ) & 100,72 & 91,18 & 114,68 \\
\hline
\end{tabular}

Nota-se que as características de extrato seco, acidez e de concentração de Cobre da fração de cabeça, seguem a mesma tendência na fração de cauda, nos três tratamentos, isto é, valores semelhantes para os tratamentos LF e IZ, que são inferiores aos do tratamento FP. Particularmente para a concentração de Cobre na fração cauda, o aumento do teor observado desta fração deve-se a alguns fatores, tais como a maior acidez, conforme descrito por Lafont, citado por Amerine e colaboradores (1972), e por Lucena (1959) e a maior temperatura no final da destilação, segundo Lima (1964).

A fração cauda do tratamento $I Z$ já não mais continha aldeídos em níveis detectáveis pela metodologia utilizada, enquanto que o teor observado em FP foi superior ao do tratamento LF, tendência também observada nas aguardentes. 
A acetona dos tratamentos LF e IZ também foram esgotadas nas frações destinadas à aguardente, sendo que em FP a fração cauda ainda continha traços deste componente.

Os teores de ésteres na fração cauda de FP são superiores aos demais tratamentos, fato que não ocorreu com a aguardente, onde era o tratamento IZ que continha maiores teores. Pode-se supor que isto se deva à uma possível menor volatilidade dos ésteres produzidos pela levedura comercial.

Quanto aos álcoois superiores, verifica-se que foram praticamente esgotados nas frações que constituíram a aguardente, com exceção feita ao n-Propanol, onde verifica-se ainda teores consideráveis na fração cauda. Estes teores podem estar associados à solubilidade deste álcool tanto em água quanto em etanol.

\subsection{Análise sensorial}

Observou-se diferença entre os três tratamentos submetidos à análise sensorial, ao nível de $5 \%$ de probabilidade, de acordo com os resultados expressos a seguir. 


\subsubsection{Teste triangular}

Tabela 7. Resultados do testes triangulares efetuados nas aguardentes

\begin{tabular}{lccc}
\hline Comparações: & LF X FP & FP X IZ & LF X IZ \\
\hline Julgamentos corretos & 12 & 12 & 12 \\
Julgamentos Errados & 09 & 09 & 09 \\
Nível de significância ( \% ) & 2,1 & 2,1 & 2,1 \\
\hline
\end{tabular}

Através dos resultados do teste triangular ilustrados pela tabela 7 , verifica-se que os tratamentos diferem entre si ao nível de significância $<5 \%$, indicando que as linhagens de levedura exercem influência sobre as características sensoriais da aguardente.

\subsubsection{Teste pareado de preferência}

Através do teste pareado, observou-se preferência pela aguardente do tratamento LF, quando confrontada com as demais, ao nível de $3,9 \%$ de probabilidade, conforme tabelas 8 e 9 .

Tabela 8. Resultados do teste pareado de preferência entre os tratamentos FP e LF.

\begin{tabular}{lc}
\hline Número de julgamentos & 12 \\
Preferências por FP & 2 \\
Preferências por LF & 10 \\
Nível de significância (\%) & 3,9 \\
\hline
\end{tabular}


Tabela 9. Resultados do teste pareado de preferência entre os tratamentos LF e IZ.

\begin{tabular}{lc} 
Número de julgamentos & 12 \\
Preferências por LF & 10 \\
Preferências por IZ & 02 \\
Nível de significância (\%) & 3,9 \\
\hline
\end{tabular}

No confronto entre IZ e FP os degustadores não manifestaram preferência ao nível de $5 \%$ de probabilidade, conforme ilustrado pela tabela 10 , apesar de existir diferença entre estas aguardentes, verificada pelo teste triangular.

Tabela 10. Resultados do teste pareado de preferência entre os tratamentos FP e IZ.

\begin{tabular}{lc}
\hline Número de julgamentos & 12 \\
Preferências por FP & 4 \\
Preferências por IZ & 8 \\
Nível de significância (\%) & $38,8^{\text {ns }}$ \\
\hline ns = não significativo &
\end{tabular}




\section{CONCLUSÕES}

Através das fermentações efetuadas com as três linhagens de levedura utilizadas na produção da aguardente de cana sob as condições deste experimento, podese concluir que:

1. Cada linhagem utilizada apresentou uma característica ímpar quanto aos parâmetros cinéticos e composição do vinho resultante da fermentação;

2. A linhagem floculante LF produziu maior biomassa e produtividade, e menor concentração de etanol, com menor eficiência;

3. A levedura floculante e $\mathrm{H}_{2} \mathrm{~S}$ negativa $\mathrm{IZ}$ - 987 produziu biomassa intermediária entre as linhagens consideradas, porém com menor produtividade em etanol. Foi superior, entretanto, em concentração alcoólica e eficiência;

4. A linhagem FP produziu menor biomassa, maior acidez, menores valores de velocidade específica de crescimento e foi intermediária nos demais parâmetros considerados entre as três linhagens. 
Em relação aos componentes secundários no vinho, conclui-se que:

5. As linhagens produzem componentes secundários em curvas de perfís semelhantes ao longo do tempo, porém quantitativamente bem distintos. LF produz aldeídos similarmente a IZ e muito menor que $\mathrm{FP}$, que é $100 \%$ maior, ao longo da fermentação. IZ é maior produtora de ésteres e também de n-Propanol, i-Butanol e álcool i-Amilico que as linhagens LF e FP.

No destilado já composto para grau real de aproximadamente $40 \%\left(\mathrm{v} \cdot \mathrm{v}^{-1}\right)$ observou-se que as análises dos destilados levam à seguinte conclusão:

6. As aguardentes foram fiéis às composições do vinho em aldeídos, ésteres e álcoois superiores, que assim se caracterizavam: LF - menor teor em ésteres, intermediário em aldeídos e em álcoois superiores; IZ - menor teor em aldeídos, maior em ésteres e em álcoois superiores; FP - maior teor em aldeídos, intermediário em ésteres e menor teor em álcoois superiores.

A análise sensorial das aguardentes destas linhagens permitiu concluir que:

7. Há influência das linhagens sobre os produtos obtidos, indicada pelo teste triangular e, através dos testes pareados, que a aguardente da linhagem LF tem preferência sobre as demais, entretanto não se consegue correlação entre as análises sensorial e de caracterização cromatográfica realizada; há que se estudar outros, ou específicos compostos que se relacionem com "flavor"ou buquê das aguardentes. 


\section{REFERÊNCIAS BIBLIOGRÁFICAS}

AMERINE, M.A. \& OUGH, C.S. Wine and must analysis. New York: John Wiley \& Sons, 1974, 121p.

AMERINE, M.A.; BERG, H.W.; CRUESS, W.V. The technology of wine making. Westport: AVI Publishing Company, 1972, $3^{\text {rd }}$ ed. 802p.

ANÔNIMO. Pinga sem a ressaca da crise. Alimentos e Tecnologia, v.3, n.2O, p. 42 - 55, Abr. 1988.

BARONE, M.C. Influência da condução do processo de fermentação sobre a qualidade e produtividade do hidromel. Piracicaba, 1994. Dissertação (mestrado) - Escola Superior de Agricultura "Luiz de Queiroz", Universidade de São Paulo. 1994, 156p.

BATIZ, H.; ROSADO, E. A single gas chromatographic method for the direct trace analysis of high boiling components in rums. Journal of Agriculture of University of Puerto Rico, v.61, n.4, p. 330-42, Jul. 1977.

BOZA, Y.E.A.G. Influência da condução da destilação sobre a composição e a qualidade sensorial da aguardente de cana. Piracicaba, 1996. Dissertação (mestrado) - Escola Superior de Agricultura “Luiz de Queiroz", Universidade de São Paulo. 140p. 
BRASL. Ministério da Agricultura. Secretaria Nacional de Defesa Agropecuária. Complementação de padrões de identidade e qualidade. Brasilia, p.11-2 (Documento oficializado pela Portaria 371, publicada no Diaário Oficial da União de 18/09/1974).

CACHOT, T. MULLER, M. \& PONS M-N. Kinetics of volatile metabolites during alcoholic fermentation of cane molasses by Saccharomyces cerevisiae. Applied Microbiology and Biotechnology, v.35, n.4, p. 450-4, Jul. 1991.

COALBRA. Cadernos COALBRA (1): produção de etanol da madeira. Brasilia: COALBRA, 1983. 117p.

COMBERBACH, D.M.; BU'LOCK, J.D. Continuous ethanol production in the gas-lift tower fermenter. Biotechnology Letters, v.6, n.2, p. 129-34, Feb. 1984.

COPERSUCAR. Fermentação. Cooperativa de Produtores de Cana, Açúcar e Álcool do Estado de São Paulo. Centro de Tecnologia Copersucar. Divisão industrial. $1^{\text {a }}$ ed. 1987. $434 \mathrm{p}$.

DE CLERCK, J. A textbook of brewing. London: Chapman \& Hall, 1957. 587 p.

FARIA, J.B. A influência do cobre na qualidade da aguardente de cana (Sacchanum officinarum, L.). São Paulo, 1989. Tese (Doutorado) - Faculdade de Ciências Farmacêuticas. Universidade de São Paulo. 88p.

FRANCO, C.J. A fermentação alcoólica. Saccharum STAB, v.1, n.3, p.31-6, 1978. 
GIUDICI, P.; KUNKEE, R.E. The effect of nitrogen deficiency and sulfur containing amino acids on the reduction of sulfate to hydrogen sulfide by wine yeasts. American Journal of Enology and Viticulture, v.45, n.1, p. 107-12, 1994.

GIUDICI, P.; ROMANO, P.; ZAMBONELLI, C. A biometric study of higher alcohol production in Saccharomyces cerevisiae. Canadian Journal of Microbiology, v.36, n.1, p.61-4, Jan. 1990.

GIUDICI,P. ZAMBONELLI, C. \& KUNKEE, R.E. Increased production of n-propanol in wine by yeast strains having a impaired ability to form hydrogen sulfide. American Journal of Enology and Viticulture, v.44, n. 1, p. 17-21, 1993.

GROBOILLOT, A.; PONS, M.N. \& ENGASSER, J.M. Monitoring of volatiles in alcoholic fermentations on molasses via a gas membrane sensor. Applied microbiology and Biotechnology, v. 32, p. 37-44, 1989

GUTIERREZ, L.E. Componentes de bebidas alcoólicas destiladas. Notícias da ESALQ, v.3, n. 16, p. 2, Dez. 1990.

HAMMOND, J.RM. Genetically-modified brewing yeasts for the 21 st century. Progress to date. Yeast, v.11, n.16, p. 1613-27, Dec. 1995.

HARRISON, J.S. \& GRAHAN, J.C.J. Yeasts in distillery practice. In: ROSE, A.H. \& HARRISON, J.S. ed. The Yeasts. vol. 3. London: Academic Press, 1970. p. 283 348. 
HART, F.L. \& FISHER, H.J. Analisis modemo de los alimentos. Zaragoza: Editorial Acribia., 1971. 619p.

HOUGH, J.S. et al. Malting and Brewing Science. $2^{\text {nd }}$ ed. New York: Chapman and Hall, 1982. $913 \mathrm{p}$.

INSTITUTO ADOLFO LUTZ. Normas analíticas do Instituto Aldolfo Lutz: volume 1 Métodos químicos e físicos para a análise de alimentos. 3 ed. São Paulo: 1985, 533p.

JACINTHO, O. A. Determinação de cobre pelo método colorimétrico do dietilditiocarbamato de sódio.Piracicaba, 1967. Tese (doutorado) - Escola Superior de Agricultura "Luiz de Queiroz", Universidade de São Paulo. 82 p.

LIBICKI, S.B.; SALMON, P.M; ROBERTSON, C.R. Effective diffusive permeability of a non reacting solute in microbial cell aggregates. Biotechnology and Bioengineering, v.32, n.1, p. 68-85, Jun. 1988.

LIMA, U.A. Aguardentes. In AQUARONE, E.; BORZANI, W. Alimentos e bebidas produzidos por fermentação. São Paulo: Edgard Blüclher, 1983. p. 79-103. Série Biotecnologia, v.5.

LIMA, U.A. Produção de etanol. In: LIMA, U.A; AQUARONE, E.; BORZANI, W. Ed. Tecnologia das fermentações. v.1. cap. 3. São Paulo: Edgard Blüclher, 1975, p. $49-69$.

LIMA, U.A. Estudo dos principais fatores que afetam os componentes do coeficiente não álcool das aguardentes de cana. Piracicaba, 1964. 141 p. (Tese-catedra - ESALQ). 
LOGAN, B.E.; HUNT, J.R. Bioflocculation as a microbial response to substrate limitations. Biotechnology and Bioengineering, v. 31, n. 2, p. 91-101, Feb. 1988.

LUCENA, V.G. O problema do cobre nas aguardentes. Brasil açucareiro, v.5, p. 14-8, 1959.

MARGALITH, P.; SCHWARTZ, Y. Flavor and microorganisms. Advances in Applied Microbiology, v.12, p.35-88. Mar. 1970.

MELONI, G. L'industria dell'alcole II. Processi e impianti di produzione e trasformazione. Le materie prime - le acquaviti. 3 ed. Milano: Ulrico Hoepli, 1979. 689p.

MORI, E.E.M. Métodos sensoriais e físicos para a avaliação de alimentos e bebidas: princípios e aplicação. Campinas: ITAL, 1992.

NEISH, A.C. Determination of reducing sugars. In: NATIONAL RESEARCH COUNCIL OF CANADA. Analytical methods for bacterial fermentation. Saskatoon: $2^{\text {ed }}$, 1952, p.34. (Report, 46-8-3).

NOBBREGA, I.C.C. Características da qualidade de aguardentes de cana comerciais e comparação entre dois processos de fermentação. (Dissertação de mestrado). Universidade Federal de Viçosa, 1994. 67p.

NOVAES, F.V. Processos fermentativos. In: MUTTON, M.J.R.; MUTTON, M.A. ed. Aguardente de cana. Jaboticabal: FUNEP, 1992. cap.4, p. 37-48.

NOVAES, F.V.; STUPIELlO, J.P.; OLIVEIRA, E.R.; VALSECHI, O. $1^{\mathbf{0}}$ Curso de extensão universitária em tecnologia de aguardente de cana. Piracicaba: 1974. $104 \mathrm{p}$. 
PARAZZI, C. Fermentą̧ão alcoólica com leveduras floculantes. (Dissertação de mestrado). UNESP, Rio Claro, 1995, 164p.

PINTO, G.L. Fabricação de aguardente. Informe Técnico n 57 . Universidade Federal de Viçosa, Viçosa: 1986, $16 \mathrm{p}$.

PIRT, S.J. Principles of microbe and cell cultivation. Oxford: Blackwell, 1985, 274p.

PRÄVE, et al. Fundamentals of biotechnology. Weinhein: VCH Verlagsgesellschaft, 1987. $792 \mathrm{p}$.

PRINCE, I.G.; BARFORD, J.P. Continuous tower fermentation for power ethanol production. Biotechnology Letters, v.4, n.4, p. 263-8, Apr. 1982.

PRINCE, I.G.; BARFORD, J.P. Induced flocculation of yeasts for use in the tower fermenter. Biotechnology Letters, v.4, n.10, p. 621-6, Oct. 1982.

PRINCE, I.G.; BARFORD, J.P. Tower fermentation of sugar cane juice. Biotechnology Letters, v.4, n.7, p. 469-74, Jul. 1982.

PRODUÇÃO DE AGUARDENTE EM 91. A Folha de São Paulo, São Paulo, 18 fev. 1993. p. 5.1 .

RAMSAY, C.M.; BERRY, D.R Effect of temperature and $\mathrm{pH}$ on the formation of higher alcohols, fatty acids and esters in the malt whisky. Food Microbiology, v.1, n.2, p.11721, Apr. 1984. 
RANK, M.; GRAM, J.; NIELSEN, K.S.; DANIELSSON, B. On line monitoring of ethanol, acetaldeyde and glycerol during industrial fermentations with Saccharomyces cerevisiae. Applied microbiology and biotechnology, v.42, n.6, p.813-7, March , 1995.

RANKINE, B.C. Nature, origin and prevention of hydrogen sulphide aroma in wines. Journal of the Science of Food and Agriculture, v.14, p.79-91, Feb. 1963.

ROESSLER, et al. Expanded statistical tables for estimating significance in pairedpreference, paired- difference, duo-trio and triangle tests. Chicago, Journal of Food Science, v.43, n.3, p.940-7, 1978.

ROSE, A.H. Economic microbiology volume1: alcoholic beverages. London: Academic Press, 1977. 760p.

ROSE, A.H.; HARRISON, J.S. The yeasts volume 2: physiology and biochemistry of yeasts. London: Academic Press, 1971, 571p.

ROSE, A.H.; HARRISON, J.S. The yeasts volume 3: yeast technology. London: Academic Press, 1970, 590p.

ROSINI, G. Wine-making by cell-recycle-batch fermentation process. Applied Microbiology and Biotecnology, v.24, n.2, p.140-3, May, 1986. 
SAKAI, L.A.; GONÇALVES, L.H.; HORII, J. Matéria seca em leveduras: comparação entre secagem em estufa e em forno de microondas. In: CONGRESSO DE INICIAÇÃO CIENTÍFICA DA ESALQ, 5. Piracicaba: 1990, Anais. ESALQ, 1990, P.74.

SALO, P. Determining the odor thresholds for some compounds in alcoholic beverages. Journal of Food Science, v. 43, n. 3, p. 95-9, 1970.

SALO, P.: NYKÄNEN, L.; SUOMALAINEN, H. Odor thresholds and relative intensities of volatile aroma components in an artificial beverage imitating whisky. Journal of Food Science, v. 37, p. 394-8, 1972.

SOUZA, M.L.; TEIXEIRA, J.A. Reduction of diffusional limitations in yeast flocs. Biotechnology Letters, v. 13, n. 12, p. 883-8, Dec. 1991.

STAMBURY, P.F.; WHITAKER, A Principles of fermentation technology. Oxford: Pergamon Press, 1986, 255p.

STRATFORD, M.; KEENAN, M.H.J. Yeast flocculation: quantification. Yeast, v.4, p.107$15,1988$.

STUPIELLO, J.P. Destilação do vinho. In: MUTTON, M.J.R; MUTTON, M.A. ed. Aguardente de cana. Jaboticabal: FUNEP, 1992. P. 67-78.

SUOMALAINEN, H. Yeasts and its effect on the flavour of alcoholic beverages. Journal of the Institute of Brewing. V.76, p.422-5, 1970. 
SUOMALAINEN, H. \& NYKÄNEN, L. Formation of aroma compounds in alcoholic beverages. Wallerstein Laboratories Communications, v.35, n.118, p. 185-198, Dec. 1972.

SUOMALAINEN, H. \& NYKÄNEN, L. The aroma components produced by yeast in nitrogen-free sugar solution. Journal of the Institute of Brewing, v. 72, p.469-79, 1966.

SUOMALAINEN, H. Yeasts esterases and aroma esters in alcoholic beverages. Journal of the Institute of Brewing, v.87, p.296-300, Sep/Oct. 1981.

SUZZI, G.; ROMANO, P.; VANNINI, L. Cell-recycle batch fermentation using immobilized cells of flocculent Saccharomyces cerevisiae wine strains. World Journal of Microbiology and Biotechnology, v.12, p.25-7, Jan. 1996.

TORRES, C.S.; AGUIAR, J.L.; GOTAY, E. A method for the statistical selection of a panel of a rum tasters. Journal of Agriculture of the University of Puerte Rico, v. 6O, n. 1, p. 105-112, Jan. 1976.

VALSECHI, O. Aguardente de cana-de-açúcar. Piracicaba: 1970. 120p. 
ZAMBONELLI, C. Ricerche genetiche sulla produzione di idrogeno solforato in Saccharomyces cerevisiae var. ellipsoideus. Annali di Microbiologia ed Enzimologia, v.14, p. 143-53, 1964.

ZAMBONELLI, C. Ricerche biometriche sulla produzione di idrogeno solforato da solfati e solfiti in Saccharomyces cerevisiae var. ellipsoideus. Annali di microbiologia ed enzimologia. Milano, v.14. p.129-41, 1964.

ZEE, J.A. Comparative composition of fusel oils in brandies made from six grape varieties and their relationship with sensory analysis. Lebensmittel-Wissenchaft und Technoiogie, n.17, p. 54-9, 1984. 


\section{APÊNDICES}




\section{APÊNDICE 1 - Resultados da cinética fermentativa dos três ensaios}

Resultados da Cinética Fermentativa - Ensaio LF - Média de 3 repetições.

\begin{tabular}{ccccccccc}
\hline & brix & \multicolumn{4}{c}{ ART $\left(\mathrm{g} .100 \mathrm{~mL}^{-1}\right)$} & \multicolumn{2}{c}{$\mathrm{X}\left(\mathrm{g} . \mathrm{L}^{-1}\right)$} & \multicolumn{2}{c}{$\mathrm{P} \%\left(\mathrm{v} . \mathrm{v}^{-1}\right)$} \\
\cline { 2 - 9 } tempo $(\mathrm{h})$ & média & $\mathrm{s}$ & média & $\mathrm{s}$ & média & $\mathrm{s}$ & média & $\mathrm{s}$ \\
\hline 0 & 14 & 0,0 & 12,91 & 0,56 & 4,00 & 0,00 & 0,00 & 0,00 \\
4 & 11 & 0,0 & 9,51 & 0,14 & 7,20 & 0,21 & 1,44 & 0,00 \\
8 & 5,7 & 0,2 & 5,54 & 0,08 & 12,70 & 1,28 & 4,10 & 0,00 \\
12 & 0,7 & 0,2 & 1,10 & 0,26 & 15,71 & 1,91 & 6,23 & 0,03 \\
16 & 0,0 & 0,0 & 0,07 & 0,00 & 15,80 & 2,20 & 6,91 & 0,04 \\
\hline
\end{tabular}

Resultados da Cinética Fermentativa - Ensaio IZ - Média de 3 repetições.

\begin{tabular}{cccccccccc}
\hline & \multicolumn{2}{c}{ brix } & \multicolumn{3}{c}{ ART $\left(\mathrm{g} .100 \mathrm{~mL}^{-1}\right)$} & \multicolumn{2}{c}{$\mathrm{X}\left(\mathrm{g} . \mathrm{L}^{-1}\right)$} & \multicolumn{2}{c}{$\mathrm{P} \%\left(\mathrm{v} . \mathrm{v}^{-1}\right)$} \\
\cline { 2 - 9 } tempo $(\mathrm{h})$ & média & $\mathrm{s}$ & média & $\mathrm{s}$ & média & $\mathrm{s}$ & média & $\mathrm{s}$ \\
\hline 0 & 14 & 0,0 & 13,10 & 0,28 & 4,00 & 0,00 & 0,00 & 0,00 \\
4 & 12,7 & 0,2 & 11,19 & 0,28 & 5,75 & 0,07 & 1,08 & 0,01 \\
8 & 9,0 & 0,0 & 7,84 & 0,12 & 9,23 & 0,17 & 3,13 & 0,07 \\
12 & 4,0 & 0,0 & 3,81 & 0,07 & 12,78 & 0,53 & 5,17 & 0,10 \\
16 & 1,2 & 0,2 & 1,17 & 0,19 & 14,87 & 0,98 & 6,59 & 0,09 \\
20 & 0,00 & 0,0 & 0,07 & 0,00 & 14,30 & 1,76 & 7,59 & 0,13 \\
\hline
\end{tabular}

$\underline{\text { Resultados da Cinética Fermentativa - Ensaio F P - Média de } 3 \text { repetições. }}$

\begin{tabular}{ccrccccccr}
\hline & \multicolumn{2}{c}{ brix } & \multicolumn{4}{c}{ ART $\left(\mathrm{g} .100 \mathrm{~mL}^{-1}\right)$} & \multicolumn{2}{c}{$\mathrm{X}\left(\mathrm{g} . \mathrm{L}^{-1}\right)$} & \multicolumn{2}{c}{$\mathrm{P} \%\left(\mathrm{v} . \mathrm{v}^{-1}\right)$} \\
\cline { 2 - 10 } tempo $(\mathrm{h})$ & média & $\mathrm{s}$ & & média & $\mathrm{s}$ & média & $\mathrm{s}$ & média & \multicolumn{1}{c}{$\mathrm{s}$} \\
\hline 0 & 14,0 & 0 & 13,42 & 0,21 & 4,00 & 0 & 0,00 & 0 \\
4 & 12,0 & 0 & 11,08 & 0,04 & 6,04 & 0,07 & 1,67 & 0,09 \\
8 & 8,5 & 0,2 & 7,74 & 0,18 & 8,49 & 0,11 & 3,60 & 0 \\
12 & 5,0 & 0 & 4,28 & 0,13 & 10,80 & 0,18 & 5,25 & 0,03 \\
16 & 2,5 & 0 & 0,44 & 0,02 & 12,59 & 0,23 & 6,57 & 0,11 \\
20 & 1,0 & 0 & 0,30 & 0,05 & 13,17 & 0,30 & 7,30 & 0,04 \\
\hline
\end{tabular}


APÊNDICE 2 - Resultados das determinações cromatográficas durante a fermentação nos três ensaios

Produção de Aldeídos - Linhagem LF - Médias de três repetições

\begin{tabular}{ccccc}
\hline $\mathrm{t}(\mathrm{h})$ & $\mathrm{S}\left(\mathrm{g} . \mathrm{L}^{-1}\right)$ & $\mathrm{X}\left(\mathrm{g} . \mathrm{L}^{-1}\right)$ & $\mathrm{P}\left(\mathrm{g} . \mathrm{L}^{-1}\right)$ & Aldeídos $\left(\mathrm{mg} . \mathrm{L}^{-1}\right)$ \\
\hline 0 & 0,00 & 4,0 & 0,00 & 0,0 \\
4 & 34,00 & 7,4 & 11,37 & 12,1 \\
8 & 73,63 & 12,7 & 32,36 & 12,8 \\
12 & 118,10 & 15,7 & 49,15 & 19,8 \\
16 & 128,37 & 15,9 & 54,52 & 12,4 \\
\hline
\end{tabular}

Produção de Aldeídos - Tratamento IZ - Médias de três repetições

\begin{tabular}{ccccc}
\hline $\mathrm{t}(\mathrm{h})$ & $\mathrm{S}\left(\mathrm{g} . \mathrm{L}^{-1}\right)$ & $\mathrm{X}\left(\mathrm{g} . \mathrm{L}^{-1}\right)$ & $\mathrm{P}\left(\mathrm{g} . \mathrm{L}^{-1}\right)$ & Aldeídos $\left(\mathrm{mg} . \mathrm{L}^{-1}\right)$ \\
\hline 0,0 & 0,00 & 4,0 & 0,00 & 0,00 \\
4,0 & 19,17 & 5,8 & 8,50 & 9,67 \\
8,0 & 52,62 & 9,2 & 24,68 & 9,23 \\
12,0 & 92,97 & 12,8 & 40,81 & 18,03 \\
16,0 & 119,34 & 14,9 & 52,04 & 16,17 \\
20,0 & 130,33 & 15,5 & 59,91 & 9,70 \\
\hline
\end{tabular}

Produção de Aldeídos - Tratamento FP - Médias de três repetições

\begin{tabular}{ccccc}
\hline $\mathrm{t}(\mathrm{h})$ & $\mathrm{S}\left(\mathrm{g} . \mathrm{L}^{-1}\right)$ & $\mathrm{X}\left(\mathrm{g} . \mathrm{L}^{-1}\right)$ & $\mathrm{P}\left(\mathrm{g} . \mathrm{L}^{-1}\right)$ & Aldeídos $\left(\mathrm{mg} . \mathrm{L}^{-1}\right)$ \\
\hline 0 & 0,00 & 4,0 & 0,00 & 0,0 \\
4 & 23,78 & 6,1 & 13,58 & 11,0 \\
8 & 56,51 & 8,6 & 28,42 & 31,7 \\
12 & 91,43 & 10,9 & 41,60 & 63,8 \\
16 & 130,55 & 12,4 & 52,44 & 47,2 \\
20 & 132,20 & 13,4 & 57,80 & 40,3 \\
\hline
\end{tabular}


Produção de Ésteres - LF - Médias de três repetições

\begin{tabular}{ccccc}
\hline $\mathrm{t}(\mathrm{h})$ & $\mathrm{S}\left(\mathrm{g} . \mathrm{L}^{-1}\right)$ & $\mathrm{X}\left(\mathrm{g} . \mathrm{L}^{-1}\right)$ & $\mathrm{P}\left(\mathrm{g} . \mathrm{L}^{-1}\right)$ & Ésteres $\left(\mathrm{mg} . \mathrm{L}^{-1}\right)$ \\
\hline 0 & 0,00 & 4,0 & 0,00 & 0,0 \\
4 & 34,00 & 7,4 & 11,37 & 2,1 \\
8 & 73,63 & 12,7 & 32,36 & 1,0 \\
12 & 118,10 & 15,7 & 49,15 & 3,1 \\
16 & 128,37 & 15,9 & 54,52 & 5,5 \\
\hline
\end{tabular}

Produção de Ésteres - IZ 987 - Médias de três repetições

\begin{tabular}{ccccc}
\hline $\mathrm{t}(\mathrm{h})$ & $\mathrm{S}\left(\mathrm{g} . \mathrm{L}^{-1}\right)$ & $\mathrm{X}\left(\mathrm{g} . \mathrm{L}^{-1}\right)$ & $\mathrm{P}\left(\mathrm{g} . \mathrm{L}^{-1}\right)$ & Ésteres $\left(\mathrm{mg} \cdot \mathrm{L}^{-1}\right)$ \\
\hline 0,0 & 0,00 & 4,0 & 0,00 & 0,00 \\
4,0 & 19,17 & 5,8 & 8,50 & 5,60 \\
8,0 & 52,62 & 9,2 & 24,68 & 3,90 \\
12,0 & 92,97 & 12,8 & 40,81 & 3,70 \\
16,0 & 119,34 & 14,9 & 52,04 & 6,63 \\
20,0 & 130,33 & 15,5 & 59,91 & 7,87 \\
\hline
\end{tabular}

Produção de Ésteres - FP - Médias de três repetições

\begin{tabular}{ccccc}
\hline $\mathrm{t}(\mathrm{h})$ & $\mathrm{S}\left(\mathrm{g} . \mathrm{L}^{-1}\right)$ & $\mathrm{X}\left(\mathrm{g} . \mathrm{L}^{-1}\right)$ & $\mathrm{P}\left(\mathrm{g} . \mathrm{L}^{-1}\right)$ & Ésteres $\left(\mathrm{mg} . \mathrm{L}^{-1}\right)$ \\
\hline 0 & 0,00 & 4,0 & 0,00 & 0,0 \\
4 & 23,78 & 6,1 & 13,58 & 1,6 \\
8 & 56,51 & 8,6 & 28,42 & 1,7 \\
12 & 91,43 & 10,9 & 41,60 & 3,7 \\
16 & 130,55 & 12,4 & 52,44 & 5,9 \\
20 & 132,20 & 13,4 & 57,80 & 6,4 \\
\hline
\end{tabular}


Produção de n-Propanol - LF - Médias de três repetições

\begin{tabular}{ccccc}
\hline $\mathrm{t}(\mathrm{h})$ & $\mathrm{S}\left(\mathrm{g} \cdot \mathrm{L}^{-1}\right)$ & $\mathrm{X}\left(\mathrm{g} \cdot \mathrm{L}^{-1}\right)$ & $\mathrm{P}\left(\mathrm{g} \cdot \mathrm{L}^{-1}\right)$ & $\begin{array}{c}\text { n-Propanol } \\
\left(\mathrm{mg} . \mathrm{L}^{-1}\right)\end{array}$ \\
\hline 0 & 0,00 & 4,0 & 0,00 & 0,0 \\
4 & 34,00 & 7,4 & 11,37 & 17,0 \\
8 & 73,63 & 12,7 & 32,36 & 19,6 \\
12 & 118,10 & 15,7 & 49,15 & 19,9 \\
16 & 128,37 & 15,9 & 54,52 & 27,4 \\
\hline
\end{tabular}

Produção de n-Propanol - IZ 987 - Médias de três repetições

\begin{tabular}{ccccc}
\hline $\mathrm{t}(\mathrm{h})$ & $\mathrm{S}\left(\mathrm{g} \cdot \mathrm{L}^{-1}\right)$ & $\mathrm{X}\left(\mathrm{g} \cdot \mathrm{L}^{-1}\right)$ & $\mathrm{P}\left(\mathrm{g} \cdot \mathrm{L}^{-1}\right)$ & $\begin{array}{c}\mathrm{n}-\text { Propanol } \\
\left(\mathrm{mg} . \mathrm{L}^{-1}\right)\end{array}$ \\
\hline 0,0 & 0,00 & 4,0 & 0,00 & 0,00 \\
4,0 & 19,17 & 5,8 & 8,50 & 22,17 \\
8,0 & 52,62 & 9,2 & 24,68 & 21,87 \\
12,0 & 92,97 & 12,8 & 40,81 & 22,60 \\
16,0 & 119,34 & 14,9 & 52,04 & 32,27 \\
20,0 & 130,33 & 15,5 & 59,91 & 25,53 \\
\hline
\end{tabular}

Produção de n-Propanol - FP - Médias de três repetições

\begin{tabular}{ccccc}
\hline $\mathrm{t}(\mathrm{h})$ & $\mathrm{S}\left(\mathrm{g} \cdot \mathrm{L}^{-1}\right)$ & $\mathrm{X}\left(\mathrm{g} \cdot \mathrm{L}^{-1}\right)$ & $\mathrm{P}\left(\mathrm{g} \cdot \mathrm{L}^{-1}\right)$ & $\begin{array}{c}\text { n-Propanol } \\
\left(\mathrm{mg} \cdot \mathrm{L}^{-1}\right)\end{array}$ \\
\hline 0 & 0,00 & 4,0 & 0,00 & 0,0 \\
4 & 23,78 & 6,1 & 13,58 & 20,2 \\
8 & 56,51 & 8,6 & 28,42 & 19,4 \\
12 & 91,43 & 10,9 & 41,60 & 19,2 \\
16 & 130,55 & 12,4 & 52,44 & 22,6 \\
20 & 132,20 & 13,4 & 57,80 & 20,5 \\
\hline
\end{tabular}


Produção de i-Butanol - LF - Médias de três repetições

\begin{tabular}{ccccc}
\hline $\mathrm{t}(\mathrm{h})$ & $\mathrm{S}\left(\mathrm{g} \cdot \mathrm{L}^{-1}\right)$ & $\mathrm{X}\left(\mathrm{g} \cdot \mathrm{L}^{-1}\right)$ & $\mathrm{P}\left(\mathrm{g} \cdot \mathrm{L}^{-1}\right)$ & $\mathrm{i}-$ Butanol$\left(\mathrm{mg} . \mathrm{L}^{-1}\right)$ \\
\hline 0 & 0,00 & 4,0 & 0,00 & 0,0 \\
4 & 34,00 & 7,4 & 11,37 & 6,6 \\
8 & 73,63 & 12,7 & 32,36 & 15,9 \\
12 & 118,10 & 15,7 & 49,15 & 24,5 \\
16 & 128,37 & 15,9 & 54,52 & 28,2 \\
\hline
\end{tabular}

Produção de i-Butanol - Tratamento IZ - Médias de três repetições

\begin{tabular}{ccccc}
\hline $\mathrm{t}(\mathrm{h})$ & $\mathrm{S}\left(\mathrm{g} \cdot \mathrm{L}^{-1}\right)$ & $\mathrm{X}\left(\mathrm{g} . \mathrm{L}^{-1}\right)$ & $\mathrm{P}\left(\mathrm{g} . \mathrm{L}^{-1}\right)$ & $\mathrm{i}-$ Butanol$\left(\mathrm{mg} . \mathrm{L}^{-1}\right)$ \\
\hline 0,0 & 0,00 & 4,0 & 0,00 & 0,00 \\
4,0 & 19,17 & 5,8 & 8,50 & 7,37 \\
8,0 & 52,62 & 9,2 & 24,68 & 12,83 \\
12,0 & 92,97 & 12,8 & 40,81 & 21,83 \\
16,0 & 119,34 & 14,9 & 52,04 & 35,00 \\
20,0 & 130,33 & 15,5 & 59,91 & 43,83 \\
\hline
\end{tabular}

Produção de i-Butanol - FP - Médias de três repetições

\begin{tabular}{ccccc}
\hline $\mathrm{t}(\mathrm{h})$ & $\mathrm{S}\left(\mathrm{g} . \mathrm{L}^{-1}\right)$ & $\mathrm{X}\left(\mathrm{g} \cdot \mathrm{L}^{-1}\right)$ & $\mathrm{P}\left(\mathrm{g} \cdot \mathrm{L}^{-1}\right)$ & $\mathrm{i}-\mathrm{Butanol}\left(\mathrm{mg} \cdot \mathrm{L}^{-1}\right)$ \\
\hline 0 & 0,00 & 4,0 & 0,00 & 0,0 \\
4 & 23,78 & 6,1 & 13,58 & 8,8 \\
8 & 56,51 & 8,6 & 28,42 & 13,5 \\
12 & 91,43 & 10,9 & 41,60 & 16,0 \\
16 & 130,55 & 12,4 & 52,44 & 22,2 \\
20 & 132,20 & 13,4 & 57,80 & 23,7 \\
\hline
\end{tabular}


APÊNDICE 3 - Resultados das determinações efetuadas sobre as frações destiladas dos três ensaios

Resultados de análises das frações destiladas - Ensaio LF - Médias de três repetições

\begin{tabular}{cccccc}
\hline $\begin{array}{c}\text { Frações } \\
(200 \mathrm{~mL})\end{array}$ & $\begin{array}{c}\mathrm{T} \\
{ }^{\circ} \mathrm{C}\end{array}$ & $\begin{array}{c}\mathrm{t} \\
(\mathrm{s})\end{array}$ & $\begin{array}{c}\mathrm{de} \\
(20 / 4)\end{array}$ & $\begin{array}{c}\text { Etanol } \\
\%\left(\mathrm{v} \cdot \mathrm{v}^{-1}\right)\end{array}$ & $\begin{array}{c}\text { acidez } \\
(\mathrm{mg} \mathrm{ac} . \text { acético.100mL }\end{array}$ \\
\hline 1 & 86 & 236,67 & 0,8716 & 75,48 & 6,16 \\
2 & 91 & 188,33 & 0,8913 & 67,68 & 5,44 \\
3 & 93 & 190,00 & 0,9044 & 62,08 & 5,60 \\
4 & 94 & 198,33 & 0,9170 & 56,39 & 6,48 \\
5 & 95 & 213,33 & 0,9287 & 50,72 & 7,12 \\
6 & 96 & 231,67 & 0,9411 & 44,10 & 7,92 \\
7 & 96 & 258,33 & 0,9533 & 36,56 & 8,64 \\
8 & 97 & 300,00 & 0,9637 & 28,81 & 9,20 \\
9 & 98 & 353,33 & 0,9725 & 21,02 & 9,52 \\
\hline
\end{tabular}

Resultados de análises das frações destiladas - Ensaio - IZ - Médias de três repetições

\begin{tabular}{|c|c|c|c|c|c|}
\hline $\begin{array}{l}\text { Frações } \\
(200 \mathrm{~mL})\end{array}$ & $\begin{array}{l}\mathrm{T} \\
{ }^{\circ} \mathrm{C} \\
\end{array}$ & $\begin{array}{c}\mathrm{t} \\
(\mathrm{s}) \\
\end{array}$ & $\begin{array}{c}\mathrm{de} \\
(20 / 4) \\
\end{array}$ & $\begin{array}{c}\text { Etanol } \\
\%\left(\mathrm{v} \cdot \mathrm{v}^{-1}\right)\end{array}$ & $\begin{array}{c}\text { acidez } \\
\left(\mathrm{mg} \text { ac. acético. } 100 \mathrm{~mL}^{-1}\right)\end{array}$ \\
\hline 1 & 88 & 202 & 0,8728 & 74,88 & 5,60 \\
\hline 2 & 91 & 170 & 0,8930 & 66,96 & 4,72 \\
\hline 3 & 92 & 170 & 0,9073 & 60,82 & 4,80 \\
\hline 4 & 93 & 172 & 0,9190 & 55,47 & 5,04 \\
\hline 5 & 94 & 178 & 0,9295 & 50,34 & 5,68 \\
\hline 6 & 95 & 185 & 0,9412 & 44,07 & 6,00 \\
\hline 7 & 96 & 197 & 0,9524 & 37,19 & 6,48 \\
\hline 8 & 96 & 208 & 0,9623 & 29,97 & 7,12 \\
\hline 9 & 97 & 222 & 0,9702 & 23,13 & 7,68 \\
\hline 10 & 97 & 235 & 0,9769 & 16,89 & 7,60 \\
\hline 11 & 98 & 260 & 0,9824 & 11,97 & 7,12 \\
\hline
\end{tabular}


Resultados de análises das frações destiladas - Ensaio FP - Médias de três repetições

\begin{tabular}{cccccc}
\hline Frações (200mL) & $\mathrm{T}^{\circ} \mathrm{C}$ & $\mathrm{t}(\mathrm{s})$ & de (20/4) & Etanol \% (v.v $\left.{ }^{-1}\right)$ & $\begin{array}{c}\text { acidez }(\mathrm{mg} \mathrm{ac} . \\
\left.\text { acético.100 } \mathrm{mL}^{-1}\right)\end{array}$ \\
\hline 1 & 86 & 167 & 0,8704 & 75,91 & 12,3 \\
2 & 91 & 175 & 0,8838 & 70,71 & 12,0 \\
3 & 93 & 172 & 0,8965 & 65,44 & 14,4 \\
4 & 94 & 180 & 0,9088 & 60,13 & 16,6 \\
5 & 94 & 193 & 0,9203 & 54,87 & 19,9 \\
6 & 95 & 205 & 0,9311 & 49,53 & 21,9 \\
7 & 96 & 225 & 0,9435 & 42,75 & 22,0 \\
8 & 97 & 243 & 0,9563 & 34,51 & 20,8 \\
9 & 97 & 277 & 0,9656 & 27,17 & 22,3 \\
10 & 98 & 323 & 0,9746 & 19,08 & 17,5 \\
\hline
\end{tabular}

